\title{
National Ignition Facility Draft Supplemental Environmental Impact Statement to the SSM PEIS
}

\section{Prepared by}

U.S. Department of Energy

Oakland Operations Office

Oakland, California 
[This page intentionally left blank.] 


\title{
COVER SHEET
}

\section{RESPONSIBLE AGENCY: U.S. Department of Energy}

\section{TITLE: National Ignition Facility Draft Supplemental Environmental Impact Statement to the SSM PEIS}

CONTACT: For additional information on this statement write or call:

\author{
Mr. Richard Scott, Document Manager \\ U.S. Department of Energy, L-293 \\ 7000 East Avenue, P.O. Box 808 \\ Livermore, CA 94550 \\ Telephone: (925) 423-3022 \\ Facsimile: (925) 424-3755 \\ Toll-free: (877) 388-4930
}

For general information on the NEPA process at DOE, write or call:

\author{
Ms. Carol M. Borgstrom, Director \\ Office of NEPA Policy and Assistance, EH-42 \\ U.S. Department of Energy \\ 1000 Independence Avenue, SW \\ Washington, DC 20585 \\ Telephone: (202) 586-4600 \\ Facsimile: (202) 586-7031 \\ Toll-free Messages: (800) 472-2756
}

\begin{abstract}
The U.S. Department of Energy (DOE) is constructing the National Ignition Facility (NIF) at Lawrence Livermore National Laboratory (LLNL) at Livermore, California. In 1997, buried capacitors containing polychlorinated biphenyls (PCBs) were discovered during site excavation for the NIF. The capacitors and contaminated soil were cleaned up to levels protective of human health and the environment in accordance with the Comprehensive Environmental Response, Compensation, and Liability Act (CERCLA) and its implementing regulations and in consultation with state and federal regulators. In October 1997, DOE entered into a Joint Stipulation and Order approved and entered as an order of the court on October 27, 1997, in partial settlement of the lawsuit Civ. No. $97-936$ (SS) (D.D.C.), Natural Resources Defense Council et al. v Richardson et al. Paragraph 7 of the Joint Stipulation and Order provides that a Supplemental Environmental Impact Statement (SEIS) shall evaluate “... the reasonably foreseeable significant adverse environmental impacts of continuing to construct and of operating NIF at LLNL with respect to any potential or confirmed contamination in the area by hazardous, toxic, and/or radioactive materials." On September 25, 1998, DOE announced in the Federal Register the agency's intent to prepare an SEIS for the NIF portion (Volume III, Appendix I) of the Programmatic Environmental Impact Statement for Stockpile Stewardship and Management (SSM PEIS) (DOE/EIS-0236, September 1996). The Joint Stipulation and Order required further investigations of potential buried wastes and of soil and groundwater contamination in seven site areas. The results of these investigations are as follows. Interviews and searches of historical information indicated a low probability of finding additional buried sources of contamination. Magnetometer, electromagnetic induction, and ground-penetrating radar surveys identified no additional potential areas of concern. In December 1998, soil sampling during routine maintenance operations identified residual PCBs in soils in the East Traffic Circle Area from a previous landfill closure. The area is outside the NIF Construction Area. The cleanup of the buried capacitors; contaminated soils; and other, nonhazardous, items found in 1997 and 1998 resulted in dust emissions. However, the risks of cancer and noncancer health effects due to PCBs on inhaled dust from the cleanups are estimated to have been orders of magnitude below levels of concern established by the U.S. Environmental Protection Agency (EPA). Information from LLNL's extensive groundwater monitoring program and new information in this SEIS regarding present and potential future groundwater concentrations of PCBs in the study areas indicate that PCB contamination levels are well below concentrations that would impact human health and the environment. Concentrations of PCBs reaching the groundwater are conservatively estimated to be less than $0.5 \%$ of EPA's current drinking water guidelines for PCBs. No impacts on human health or the environment would result from this low level of potential contamination.
\end{abstract}


[This page intentionally left blank.] 


\section{SUMMARY}

This Supplemental Environmental Impact Statement (SEIS) is being prepared pursuant to a Joint Stipulation and Order approved and entered as an order of the court on October 27, 1997, in partial settlement of the lawsuit Civ. No.97-936 (SS) (D.D.C.), Natural Resources Defense Council [NRDC] et al. $v$ Richardson et al. The Joint Stipulation and Order is reproduced at the end of this document as Attachment 1. In the Joint Stipulation and Order, the U.S. Department of Energy (DOE) agreed to prepare an SEIS to the Programmatic Environmental Impact Statement for Stockpile Stewardship and Management (SSM PEIS) (DOE/EIS-0236, DOE 1996a) to evaluate the reasonably foreseeable significant adverse environmental impacts of continuing to construct and of operating the National Ignition Facility (NIF) at Lawrence Livermore National Laboratory (LLNL) in Livermore, California, with respect to any potential or confirmed contamination in the area by hazardous, toxic, and/or radioactive materials. On September 25, 1998, DOE announced in the Federal Register the agency's intent to prepare this SEIS for the NIF portion (Volume III, Appendix I) of the SSM PEIS. DOE's need for preparation of this SEIS, consistent with the previously established need for NIF (DOE 1996a, Appendix I), is to determine how the results of characterization studies completed pursuant to the Joint Stipulation and Order should affect the manner in which DOE proceeds with the construction and operation of NIF. On August 5, 1999, DOE issued an amended Notice of Intent to prepare this SEIS, which incorporated changes in schedule resulting from new relevant information.

The SSM PEIS addressed alternative plans for DOE's defense program activities related to nuclear weapons stockpile issues at several DOE laboratories, including LLNL. The environmental consequences of construction and operation of NIF were addressed in detail in SSM PEIS Volume III, Appendix I, entitled National Ignition Facility Project Specific Analysis (NIF PSA). The Record of Decision (ROD) for the SSM PEIS was published in the Federal Register on December 26, 1996 (61 FR 68014). In the ROD, DOE announced its decision to construct and operate NIF at LLNL. The start of physical construction of NIF was authorized on March 7, 1997, and groundbreaking for the NIF occurred on May 29, 1997. Construction of the NIF is ongoing and is expected to be completed by October 2003.

On September 3, 1997, excavation activities at the NIF site uncovered capacitors containing polychlorinated biphenyl (PCB) oil, as well as some nonhazardous items. Continued excavation was cordoned off from the rest of the site, and construction activities in this area were halted from September 3 through September 12, 1999. Several of the capacitors had leaked, contaminating the surrounding soil. Analysis of composite soil samples collected in the vicinity of the capacitors indicated that soil contained PCBs at concentrations up to 66 parts per million (ppm). This level is greater than the U.S. Environmental Protection Agency (EPA) Region 9 preliminary remediation goal (PRG) of $1.3 \mathrm{ppm}$ for general PCBs in soils of an industrial site. The PCB-containing capacitors and PCB-contaminated soils were removed from the NIF Construction Area on September 12, 1997. This cleanup was conducted under the oversight of the Comprehensive Environmental Response, Compensation, and Liability Act (CERCLA) Remedial Project Managers (RPMs) for the Livermore Site. Under the CERCLA process, the RPMs for the Livermore Site (consisting of the EPA, the California Regional Water Quality Control Board-San Francisco Bay Region, and the California Department of Toxic Substances 
Control) review remedial or response actions resulting from releases of hazardous substances into the environment. The CERCLA RPMs agreed to a soil cleanup level of $1 \mathrm{ppm}$ for soils in the NIF Construction Area. This level was based on the reporting limit used for soil analysis, which represents a cleanup level more stringent than the EPA Region 9 Preliminary Remediation Goal (PRG) of $1.3 \mathrm{ppm}$ for unspecified PCBs in soils of an industrial site. All soils having PCBs above 1 ppm were removed and disposed of as hazardous waste.

On September 22, 1997, the plaintiffs in NRDC v. Richardson filed a motion under Rule 60(b) of the Federal Rules of Civil Procedure in which they alleged that DOE knew but did not adequately analyze and disclose the risk of building the NIF in an area that might contain buried hazardous, toxic, or radioactive materials or waste. DOE denied the allegations in the plaintiffs' motion. In the Joint Stipulation and Order of October 27, 1997, which settled all claims in the plaintiffs' Rule 60(b) motion, DOE agreed to conduct an assessment of “... the reasonably foreseeable significant adverse environmental impacts of continuing to construct and of operating NIF at LLNL with respect to any potential or confirmed contamination in the area by hazardous, toxic, and/or radioactive materials" and to present the results in an SEIS.

Over the period October 7-12, 1998, workers uncovered debris while conducting routine drainage maintenance operations in the center of the East Traffic Circle (ETC), the known location of a LLNL landfill remediated in 1984. These maintenance activities were not related to NIF construction and were physically separated from the NIF construction site. However, the ETC Area is one of the seven areas of concern identified in the Joint Stipulation and Order and is addressed in this SEIS. The ETC landfill was known to have contained the PCB Aroclor 1254, and tests determined that soil removed from the ETC Area contained this specific PCB compound. The RPMs were immediately notified, and subsequent actions, such as soil disposal, geophysical surveys, and soil sampling, were determined and implemented with the regulatory agencies' concurrence. Analysis of composite samples from soils excavated at the ETC Area indicated that the soil contained Aroclor 1254 at 98 and $120 \mathrm{ppm}$. With CERCLA RPM concurrence, the excavated PCB-contaminated soil was removed and sent to Enviro-Safe, Inc., an off-site hazardous waste disposal facility in Idaho. The cleanup level agreed upon by the CERCLA RPMs was less than 18 ppm, which is the EPA Region 9 PRG for Aroclor 1254 in soils at an industrial site. This cleanup level differed from the cleanup level for the NIF site because the contaminant at the ETC Area was known to be Aroclor 1254. After cleanup, the areas where the soil was stored before disposal were sampled to verify that no residual PCB contamination remained.

The seven areas at LLNL designated for additional investigation under terms of the Joint Stipulation and Order occupy a large portion of the northeastern corner of the Livermore Site. Site characterization activities required by the Joint Stipulation and Order consisted of two phases. Phase I included review of all available information and interviews with workers and retirees who were reasonably known to have knowledge of the potential existence and location of buried materials in the stipulated areas. Phase II included geophysical surveys of locations suspected of containing buried material, followed by soil boring and/or soil vapor studies where potential burial sites were identified. The progress of characterization was described in seven 
quarterly reports issued in November 1997; February, May, August, and November 1998; and March and June 1999 (DOE 1997, 1998a-d, 1999b-c).

Phase I examination of records, interviews of employees and retirees, and examination of aerial photographs narrowed the area for geophysical studies for buried materials to the Helipad Area, the Northern Boundary Area, and the NIF Construction Area. In the NIF Construction Area, magnetometer, electromagnetic induction, and ground-penetrating-radar surveys did not identify any additional locations of potential hazardous waste, while the digging of test holes identified the presence of debris (concrete, asphalt, wood, and cuttings). Other boreholes indicated the presence of nails and wire. Electromagnetic induction and magnetometer surveys of the Helipad Area also did not identify any buried objects of potential concern. A magnetometer survey was performed at the Northern Boundary Area, and no objects of potential concern were found.

Similarly, review of information on the ETC Area, including interviews and historical searches, indicated that there was a low likelihood of finding any additional buried sources of contamination. In addition, a magnetometer survey and subsurface investigations were conducted in the area under the oversight of the CERCLA RPMs. These investigations failed to locate any additional buried hazardous objects.

Phase II activities included additional sampling and analysis of soils and groundwater and examination of existing data. The Livermore Site has an extensive subsurface soil and groundwater monitoring program. Since 1986, an integrated sample and data management program has supported the collection, validation, interpretation, and use of the soil and groundwater data. A highly concentrated groundwater monitoring network within the $1-\mathrm{mi}^{2}$ Livermore Site consists of more than 1,000 boreholes and about 450 regularly monitored wells. Potential source areas were investigated during the CERCLA Remedial Investigation for the Livermore Site. Source investigations, including use of new sampling wells, were conducted on known or suspected landfills on the basis of anecdotal information and aerial photographs. Soil and groundwater were sampled for PCBs near the NIF construction site where PCB contamination was suspected. PCBs in soils are relatively immobile, and no analytical data have identified PCBs in groundwater. At the ETC Area, downgradient groundwater monitoring wells were installed to evaluate groundwater for PCBs. None were detected.

This SEIS addresses the potential environmental impacts on human health from inhalation of PCB-contaminated dust and potential contamination of groundwater resulting from the cleanup of the capacitors and contaminated soils from the NIF site and of residual contamination in the ETC Area. Excavation and removal resulted in brief periods of emissions of dust containing PCBs. The resulting risks of cancer and noncancer health effects on the public and workers are estimated to have been orders of magnitude below levels of concern established by the EPA. The cleanup levels of 1 ppm PCBs in soils of the NIF Construction Area and of $18 \mathrm{ppm}$ in soils of the ETC Area, established in coordination with the CERCLA RPMs, would be protective of human health and the environment. 
Projected levels of groundwater contamination in the NIF Construction Area and the ETC Area now and in the future are estimated to be well below levels considered to present a risk to the public. Ongoing remediation activities will continue to improve groundwater quality regardless of continued construction and operation of the NIF. None of the activities for construction and operation of the NIF would affect groundwater quality in the areas studied.

Impacts on the environment of both alternatives - (1) continue to construct and then operate the NIF at LLNL and (2) cease construction of the NIF — would be similar, except as noted below. Ceasing construction of NIF, whether for an alternative use or demolition, would prolong construction- or construction-like impacts. Radionuclide releases could occur during reuse, but would not occur during demolition. Demolition would also result in temporary dust releases above state standards and would generate approximately 4,400 $\mathrm{m}^{3}$ (about 5,800 $\mathrm{yd}^{3}$ ) of nonhazardous waste. Truck traffic from transportation of fill and wastes might temporarily disturb a state-protected bird species. Concentrations of PCBs in soil or groundwater originating from buried material would be below any level of regulatory concern for all alternatives. 


\section{CONTENTS}

COVER SHEET

iii

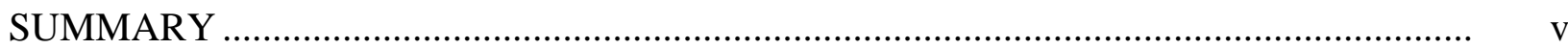

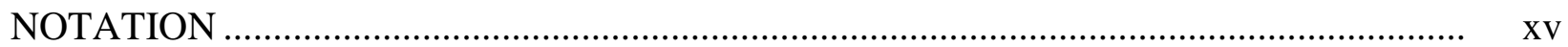

1 INTRODUCTION

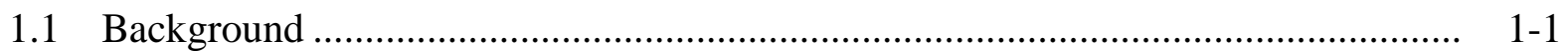

1.2 Purpose and Need .................................................................................... 1-3

1.3 Requirements of the Joint Stipulation and Order ............................................... 1-4

1.3.1 Phase I and Phase II Investigations ........................................................... 1-4

1.3.2 Stipulated Areas ........................................................................... 1-4

1.3.3 Supplemental Environmental Impact Statement ....................................... 1-7

1.4 Comments Received on the Notice of Intent ...................................................... 1-7

2 PROPOSED ACTION AND ALTERNATIVES ……………………………….............. 2-1

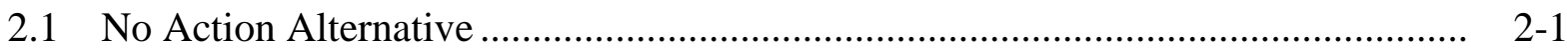

2.1.1 No Action as an Ongoing Activity ............................................................ 2-1

2.1.2 No Action as Ceasing Construction of NIF at LLNL …………….............. 2-2

2.2 Action Alternatives .......................................................................................... 2-3

2.3 Summary of Impacts ........................................................................................ 2-3

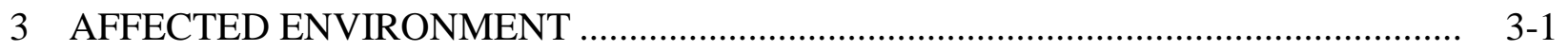

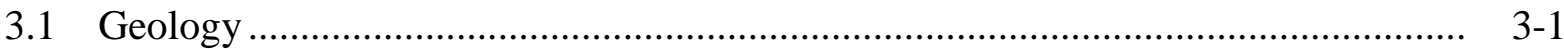

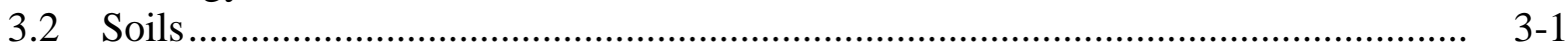

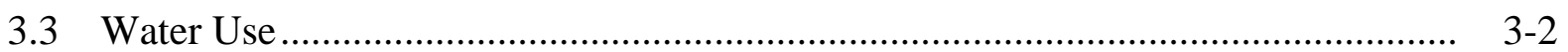

3.4 Surface Water ......................................................................................... $3-2$

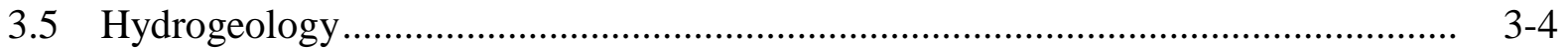

3.6 Soil and Groundwater Quality..................................................................... 3-6

3.6.1 Contaminants............................................................................. 3-6

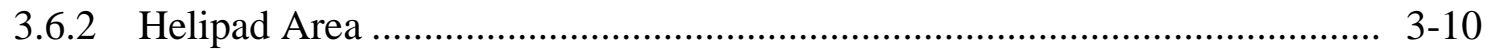

3.6.3 Building 571 Area ..................................................................... 3-13

3.6.4 Northern Boundary Area .................................................................... 3-13

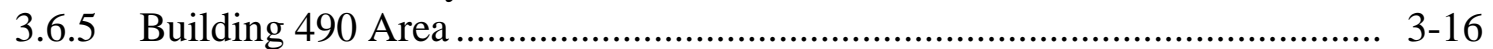

3.6.6 East Traffic Circle Area ………….................................................. 3-21

3.6.7 East Gate Drive Area.................................................................... 3-24

3.6.8 NIF Construction Area .......................................................................... 3-27

3.7 Ongoing Remediation Activities at the Site ........................................................ 3-27 


\section{CONTENTS (Cont.)}

4 ENVIRONMENTAL IMPACTS ........................................................................

4.1 Phase I and Phase II Characterization Activities .................................................... 4- 4-1

4.1.1 Summary of Phase I Results................................................................... 4-1

4.1.2 Summary of Phase II Results .................................................................. 4-3

4.1.2.1 NIF Construction Area ............................................................. 4. 4

4.1.2.2 Helipad and East Traffic Circle Areas ........................................ 4. 4-5

4.1.2.3 Northern Boundary Area ............................................................. 4. 4

4.2 Consequences of Continuing to Construct and Operate the NIF ............................ 4-7

4.2.1 Impacts from Soil Suspended in Ambient Air

from Capacitor Removal during NIF Construction.................................... 4. 4-8

4.2.2 Impacts to Soil from Operation of the NIF ………................................... 4. 4-9

4.2.3 Impacts from Soil Contaminant Migration to Groundwater during Construction and Operation of the NIF..................................................... 4- 4-

4.2.4 Impacts to Groundwater from Operation of the NIF................................. 4-14

4.3 Consequences of Ceasing NIF Construction........................................................ 4-14

4.4 Cumulative Impacts.................................................................................... 4-17

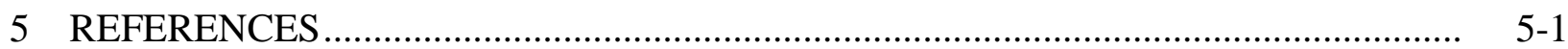

APPENDIX A: Potential Health Impacts from Exposure to $\mathrm{PM}_{10}$-Borne PCBs from Recent Remediation Actions ...................................................... A-1

APPENDIX B: $\quad$ Modeling Groundwater Impacts from the PCB Capacitor Landfill....... B-1

ATTACHMENT 1: Joint Stipulation and Order ................................................................. At1-1

ATTACHMENT 2: Notice of Intent ……………………............................................... At2-1

ATTACHMENT 3: Amended Notice of Intent ..................................................................... At3-1

\section{TABLES}

3.1 Compilation of Historic Maximum Analyte Concentrations in Soil/Sediments for the Seven Study Areas

3.2 Compilation of Historic Maximum, 1997, and Current Analyte Concentrations for Groundwater Samples from the Seven Study Areas.

A.1 Estimated Total $\mathrm{PM}_{10}$ Emissions from PCB-Contaminated Soils Associated with Cleanup Activities at the NIF Site 


\section{TABLES (Cont.)}

A.2 Estimated Total $\mathrm{PM}_{10}$ Emissions from PCB-Contaminated Soils Associated with Cleanup Activities at the East Traffic Circle Area

A.3 Intake Parameters, Computed Intakes, and Computed Excess Cancer Risks and Noncancer Impacts for Hypothetical Exposures to Airborne PCBs from Recent Remedial Actions at the NIF Construction Area and East Traffic Circle Area.

B.1 Aroclor Properties

\section{FIGURES}

1.1 Areas Identified for Further Investigation in the Joint Stipulation and Order............. 1-5

3.1 Surface Water Features near Lawrence Livermore National Laboratory .................... 3-3

3.2 Generalized Cross Section Showing Hydrostratigraphic Units beneath the Livermore Site

3.3 Eastern Portion of the Livermore Site Showing Groundwater Wells and Approximate Area Containing VOCs over the Maximum Contaminant Levels in 1998

3.4 Soil Concentrations for the Helipad Area and EPA Region 9 Industrial Preliminary Remediation Goals

3.5 Groundwater Concentrations for the Helipad Area and Maximum

Concentration Limits for Drinking Water

3.6 Soil Concentrations for the Building 571 Area and EPA Region 9

Industrial Preliminary Remediation Goals

3.7 Groundwater Concentrations for the Building 571 Area and Maximum Concentration Limits for Drinking Water.....

3.8 Soil Concentrations for the Northern Boundary Area and EPA Region 9 Industrial Preliminary Remediation Goals

3.9 Groundwater Concentrations for the Northern Boundary Area and Maximum Concentration Limits for Drinking Water. 


\section{FIGURES (Cont.)}

3.10 Soil Concentrations for the Building 490 Area and EPA Region 9

Industrial Preliminary Remediation Goals

3.11 Groundwater Concentrations for the Building 490 Area and Maximum

Concentration Limits for Drinking Water.

3.12 Soil Concentrations for the East Traffic Circle Area and EPA Region 9

Industrial Preliminary Remediation Goals

3.13 Groundwater Concentrations for the East Traffic Circle Area and Maximum

Concentration Limits for Drinking Water.

3.14 Soil Concentrations for the East Gate Drive Area and EPA Region 9

Industrial Preliminary Remediation Goals.

3.15 Groundwater Concentrations for the East Gate Drive Area and Maximum

Concentration Limits for Drinking Water.

3.16 Soil Concentrations for the NIF Construction Area and EPA Region 9

Industrial Preliminary Remediation Goals

3.17 Groundwater Concentrations for the NIF Construction Area and Maximum

Concentration Limits for Drinking Water.

3.18 Planned and Existing Groundwater and Soil Vapor Extraction Locations

at the LLNL Site.....

3.19 Groundwater Elevation Contour Map Based on Water Levels Collected from 130 Wells Completed within HSU 1B Showing Estimated Hydraulic Capture Areas, LLNL and Vicinity, February 1999

3.20 Groundwater Elevation Contour Map Based on Water Levels Collected from 167 Wells Completed within HSU 2 Showing Estimated Hydraulic Capture Areas, LLNL and Vicinity, February 1999

3.21 Groundwater Elevation Contour Map Based on Water Levels Collected from 63 Wells Completed within HSU 3A Showing Estimated Hydraulic Capture Areas, LLNL and Vicinity, February 1999

3.22 Groundwater Elevation Contour Map Based on Water Levels Collected from 25 Wells Completed within HSU 3B Showing Estimated Hydraulic Capture Areas, LLNL and Vicinity, February 1999 


\section{FIGURES (Cont.)}

3.23 Groundwater Elevation Contour Map Based on Water Levels Collected from 35 Wells Completed within HSU 4 Showing Estimated Hydraulic Capture Areas, LLNL and Vicinity, February 1999

3.24 Groundwater Elevation Contour Map Based on Water Levels Collected from 46 Wells Completed within HSU 5 Showing Estimated Hydraulic Capture Areas, LLNL and Vicinity, February 1999

3.25 Location of Monitor Well W-273 Downgradient of the NIF Construction Site.

4.1 Locations of the Capacitor, Drum, and Western Excavations at the NIF Construction Site and Location of the East Traffic Circle...

4.2 Water Table Breakthrough Curve for PCB (Aroclor 1242) at the NIF Construction Site.

B.1 Location of the NIF Construction Site at the LLNL Livermore Site

B.2 Location of the Capacitor, Drum, and Western Excavations at the NIF Construction Area and Location of the East Traffic Circle Area.

B.3 Water Table Breakthrough Curve for PCB at the NIF Construction Area B-10 
[This page intentionally left blank.] 


\section{NOTATION}

The following is a list of the acronyms, abbreviations, and units of measure used in this report. Notation used only in equations and tables is defined in those equations and tables.

\section{ACRONYMS AND ABBREVIATIONS}

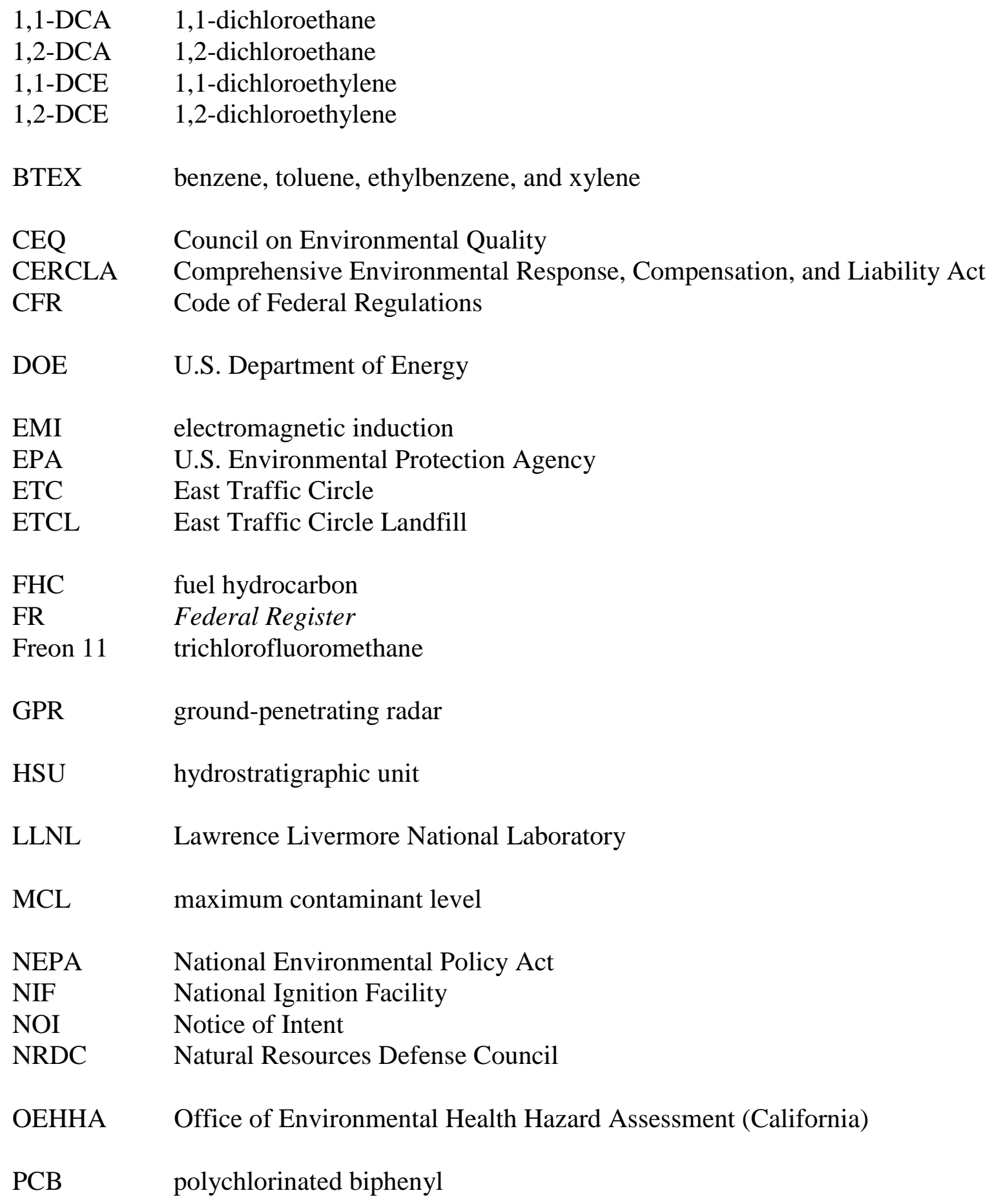




$\begin{array}{ll}\text { PCE } & \begin{array}{l}\text { perchloroethylene } \\ \text { PEIS }\end{array} \\ \text { PM }_{10} & \begin{array}{l}\text { programmatic Environmental Impact Statement } \\ \text { equal to or less than } 10 \mu \mathrm{m}\end{array} \\ \text { PRG } & \begin{array}{l}\text { preliminary remediation goal } \\ \text { Project Specific Analysis }\end{array} \\ \text { PSA } & \text { Record of Decision } \\ \text { ROD } & \text { Remedial Project Manager } \\ \text { RPM } & \text { Supplemental Environmental Impact Statement } \\ \text { SEIS } & \begin{array}{l}\text { Sandia National Laboratories } \\ \text { SNL }\end{array} \\ \text { SSM } & \text { Stockpile Stewardship and Management } \\ \text { SVS } & \text { soil vapor survey } \\ \text { TCE } & \text { trichloroethylene } \\ \text { VOC } & \text { volatile organic compound }\end{array}$

\section{Units of Measure}

$\begin{array}{llll}\mathrm{cm} & \text { centimeter(s) } & \mathrm{m} & \text { meter(s) } \\ \mathrm{cm}^{3} & \text { cubic meter(s) } & \mu \mathrm{m} & \text { micrometer(s) } \\ \mathrm{d} & \text { day(s) } & \mathrm{mm} & \text { millimeter(s) } \\ \mathrm{ft} & \text { foot (feet) } & \mathrm{mi} & \text { mile(s) } \\ \mathrm{g} & \text { gram(s) } & \mathrm{mi}^{2} & \text { square mile(s) } \\ \mu \mathrm{g} & \text { microgram(s) } & \mathrm{pCi} & \text { picocurie(s) } \\ \mathrm{mg} & \text { milligram(s) } & \mathrm{ppb} & \text { part(s) per billion } \\ \mathrm{gal} & \text { gallon(s) } & \mathrm{ppm} & \text { part(s) per million } \\ \mathrm{in} . & \text { inch(es) } & \mathrm{s} & \text { second(s) } \\ \mathrm{km} & \text { kilometer(s) } & \mathrm{yd} & \text { cubic yard(s) } \\ \mathrm{L} & \text { liter(s) } & \mathrm{yr} & \text { year(s) }\end{array}$





\section{NATIONAL IGNITION FACILITY DRAFT SUPPLEMENTAL ENVIRONMENTAL IMPACT STATEMENT TO THE SSM PEIS}

\section{INTRODUCTION}

This Supplemental Environmental Impact Statement (SEIS) is being prepared pursuant to a Joint Stipulation and Order approved and entered as an order of the court on October 27, 1997, in partial settlement of the lawsuit Civ. No.97-936 (SS) (D.D.C.), Natural Resources Defense Council [NRDC] et al. v Richardson et al. (Attachment 1). In the Joint Stipulation and Order, the U.S. Department of Energy (DOE) agreed to prepare an SEIS to the Programmatic Environmental Impact Statement for Stockpile Stewardship and Management (DOE/EIS-0236) (SSM PEIS) (DOE 1996a) evaluating specific issues related to the National Ignition Facility (NIF). The Notice of Intent (NOI) to prepare the SEIS was published in the Federal Register on September 25, 1998 (63 FR 51341) (Attachment 2). This NOI was amended on August 5, 1999 (Attachment 3).

\subsection{BACKGROUND}

The SSM PEIS addressed alternative plans for DOE's defense program activities related to nuclear weapons stockpile issues at several DOE laboratories, including Lawrence Livermore National Laboratory (LLNL) in Livermore, California. The environmental consequences of construction and operation of the NIF were addressed in detail in the SSM PEIS, Volume III, Appendix I, entitled National Ignition Facility Project Specific Analysis (NIF PSA). The NIF PSA analyzed four alternative site locations and two design options for NIF, as well as the no action alternative of not constructing and operating NIF. The analysis concluded that the impacts of constructing and operating NIF would be minor, including a very low radiation dose to the public during operation and an extremely low potential for an accident resulting in radiation releases. Doses from these sources would be well below levels set in applicable regulations and guidelines. The analysis estimated that the impacts from such an accident would be small. The PSA concluded that there would be few significant differences in adverse impacts among the alternative sites. The Record of Decision (ROD) for the SSM PEIS was published in the Federal Register on December 26, 1996 (61 FR 68014). In the ROD, DOE announced its decision to construct and operate NIF at LLNL. Groundbreaking occurred on May 29, 1997. Construction of the NIF is ongoing and is expected to be completed by October 2003.

On September 3, 1997, excavation activities at the NIF site uncovered capacitors containing a polychlorinated biphenyl (PCB) oil, as well as some nonhazardous items. Several of the capacitors had leaked, contaminating surrounding soil with Diaclor, a mixture of several PCBs (Bainer and Berg 1998). The possibility of such an occurrence was unforeseen and therefore not addressed in the SSM PEIS. A total of 112 capacitors, 694 metric tons (766 short tons) of PCB-contaminated soil, and approximately 75 corroded waste drums were promptly 
removed, and the site was cleaned up in accordance with applicable federal, state, and local requirements under a Comprehensive Environmental Response, Compensation, and Liability Act (CERCLA) removal action under paragraph 300.415 of the National Contingency Plan (40 CFR 300). This cleanup was conducted in September 1997 by LLNL with oversight by DOE and in coordination with the CERCLA Remedial Project Managers (RPMs). The RPMs represent the U.S. Environmental Protection Agency (EPA), the California Department of Toxic Substances Control, and the California Regional Water Quality Control Board-San Francisco Bay Region. The CERCLA RPMs agreed to a soil cleanup standard of 25 parts per million (ppm) based on Toxic Substances Control Act (TSCA) guidance if the soil could be reused at the NIF construction site. It was later determined that most of the soil did not meet the engineering criteria for reuse at the construction site and would need to be shipped to an approved off-site hazardous waste disposal facility. To expedite removal and to avoid further delay in NIF construction, a cleanup level of 1 part per million (ppm) was proposed and agreed to by the RPMs. This level was the reporting limit for chemical analysis of these soils and was consistent with the EPA Region 9 Preliminary Remedial Goal (PRG) of $1.3 \mathrm{ppm}$ for unspecified PCBs in soils of an industrial site.

On September 22, 1997, the plaintiffs in NRDC v. Richardson filed a motion under Rule 60(b) of the Federal Rules of Civil Procedure in which they alleged that DOE knew but did not adequately analyze and disclose the risk of building NIF in an area that may contain buried hazardous, toxic, and/or radioactive materials or waste. DOE denied the allegations in the plaintiffs' motion. In the Joint Stipulation and Order of October 27, 1997, which settled all claims in the plaintiffs' Rule 60(b) motion, DOE agreed to conduct an assessment of “... the reasonably foreseeable significant adverse environmental impacts of continuing to construct and of operating NIF at LLNL with respect to any potential or confirmed contamination in the area by hazardous, toxic, and/or radioactive materials" and to present the results in an SEIS (this document). ${ }^{1}$

As agreed upon in the Joint Stipulation and Order (Attachment 1), DOE conducted characterization studies to determine the presence of any additional buried hazardous, toxic, and/or radioactive materials in the northeastern corner of LLNL, where the NIF site is located. The progress of the characterization activities was documented to the court in quarterly reports (DOE 1997, 1998a-d, 1999b-c). Those characterization activities are now complete, and the results are analyzed in this SEIS. As discussed in Sections 2.3 and 4, the characterization studies did not detect the presence of any additional buried hazardous, toxic, and/or radioactive materials that would adversely impact human health and the environment.

\footnotetext{
1 On April 30, 1997, the NRDC and 38 other environmental and antinuclear groups filed a complaint and a motion for a preliminary injunction against DOE, alleging, among other things, that the SSM PEIS failed to analyze the environmental impacts of, and the reasonable alternatives to, construction and operation of the NIF at LLNL. On August 8, 1997, the U.S. District Court for the District of Columbia denied the plaintiffs' motion for preliminary injunction. In their September 22, 1997, Rule 60(b) motion, the plaintiffs renewed their request for a preliminary injunction as it applied to the NIF; that request was resolved by the October 27, 1997, Joint Stipulation and Order. On August 18, 1998, the court granted DOE's motion for partial summary judgment, including that portion dealing with all other issues raised by the plaintiffs relating to the NIF. Therefore, preparation of this SEIS pursuant to the Joint Stipulation and Order resolves all the remaining issues in NRDC v. Richardson regarding the NIF.
} 
Over the period October 7-12, 1998, approximately 1 year after the Joint Stipulation and Order, workers conducting routine drainage maintenance operations in the center of the East Traffic Circle (ETC) Area uncovered debris (wood, metal, plastic, etc.) while trenching down to

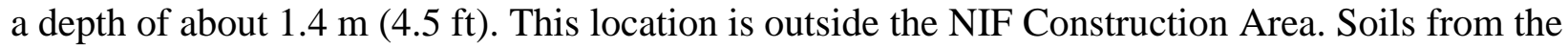
ETC Area were tested, and the PCB Aroclor 1254 was found. This PCB is believed to represent residual contamination from capacitors previously excavated during the ETC Landfill Closure in 1984. The soil removed for the drainage maintenance operations was stored on plastic in an area away from the excavation, and two composite samples were collected for chemical analyses. On December 18, 1998, the two samples were confirmed to contain Aroclor 1254 at 98 and $120 \mathrm{ppm}$. No other chemical constituents of concern (volatile organic compounds, metals, and radionuclides) were detected. After it was confirmed that the soil removed from the ETC Area contained Aroclor 1254, the RPMs were immediately notified. Subsequent actions, such as soil disposal, geophysical surveys, and soil sampling, were planned and implemented with the RPMs' concurrence. The cleanup level agreed to by the RPMs was 18 ppm, which is the EPA Region 9 PRG for Aroclor 1254 in soils at an industrial site. During the week of January 4, 1999, the PCB-contaminated soil was sent to an off-site EPA-approved hazardous waste disposal facility. With the approval of the RPMs, sampling was conducted to verify that no residual contamination remained where the soil was stored and loaded for off-site disposal.

The extent of the residual contamination remaining after PCB removal was assessed, and although interviews and historical searches indicated that there was a low likelihood of finding any additional buried sources of contamination, surface geophysical surveys and sediment sampling were conducted in the area under the oversight of the CERCLA RPMs. Soil samples

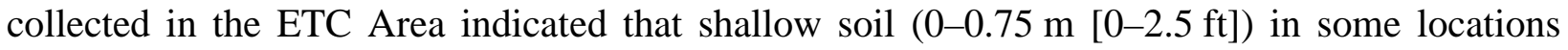
contained residual PCB concentrations above the cleanup level of $18 \mathrm{ppm}$ required by the CERCLA RPMs. With approval of the RPMs, surface soil was scraped off of these areas and confirmatory samples were collected to determine the concentrations in the remaining surface soil. Areas where residual Aroclor 1254 concentrations were still above the cleanup level were scraped until eventually the surface soil concentrations were below 18 ppm (Bainer 1999).

On August 5, 1999, DOE issued an amended NOI for preparation of this SEIS for the SSM PEIS (64 FR 42681). The amended NOI announced the revised schedule for preparation of the Draft SEIS.

\subsection{PURPOSE AND NEED}

The purpose and need for the NIF is explained in the SSM PEIS (DOE 1996a, Section I.2) and is summarized here. The NIF will provide a unique capability as a key component of DOE's science-based stewardship of the nation's nuclear weapons stockpile. Planned experiments with NIF, at temperatures and pressures near those that occur in nuclear weapon detonations, will provide data needed to verify certain aspects of sophisticated computer models. As explained in the SSM PEIS, those models are needed to simulate weapons physics, thereby providing insights on the reliability of the weapon stockpile (DOE 1996a, Section I.2.2.3). As a multipurpose inertial confinement fusion facility, the NIF will also be 
important to national energy (e.g., next critical step in scientific evaluation of inertial fusion energy as a future environmentally attractive energy source), basic science (e.g., providing insight to the origin of the universe), and technology (e.g., developing new technologies to aid U.S. industrial competitiveness in optics, lasers, and integrated circuit manufacturing) missions.

DOE's purpose and need for the preparation of this SEIS, consistent with the previously established need for NIF, is to determine how the results of the characterization studies completed pursuant to the Joint Stipulation and Order should affect the manner in which DOE proceeds with construction and operation of the NIF.

\subsection{REQUIREMENTS OF THE JOINT STIPULATION AND ORDER}

\subsubsection{Phase I and Phase II Investigations}

The site characterization activities necessary to meet the requirements of the Joint Stipulation and Order (Paragraphs 2-5) were carried out in two phases. Phase I, as defined in Paragraph 2, required a review of all available reports, studies, maps, aerial photographs, and other available records, as well as interviews with workers and retirees who are reasonably known to have knowledge of the potential existence and location of buried materials containing the mentioned substances in any of seven specified areas around and including the NIF construction site. Phase II consisted of the remainder of the required activities, as summarized here. Paragraph 3 required that in the event that activities under Paragraph 2 identified any areas where the materials in question may have been buried, appropriate geophysical surveys be carried out to further investigate such areas. Potential hazardous waste burial sites, according to Paragraph 4, would then be investigated by, at a minimum, conducting soil boring and/or soil vapor surveys. Finally, Paragraph 5 required the construction of one or more groundwater monitoring wells in the affected areas to monitor impacts from dewatering activities at the NIF construction site.

The Joint Stipulation and Order required (in Paragraph 6) that during performance of the activities in Phases I and II, DOE file a report every 90 days (1) summarizing the progress made in conducting the analyses in Phases I and II and in constructing the NIF, and (2) describing the analyses and NIF construction activities planned for the next 90-day period. DOE has filed seven such reports — in November 1997; February, May, August, and November 1998; and March and June 1999 (DOE 1997, 1998a-d, 1999b-c).

\subsubsection{Stipulated Areas}

The seven areas covered by the Joint Stipulation and Order occupy a large portion of the northeastern quadrant of the Livermore Site. Figure 1.1 shows that six of the areas occupy a 


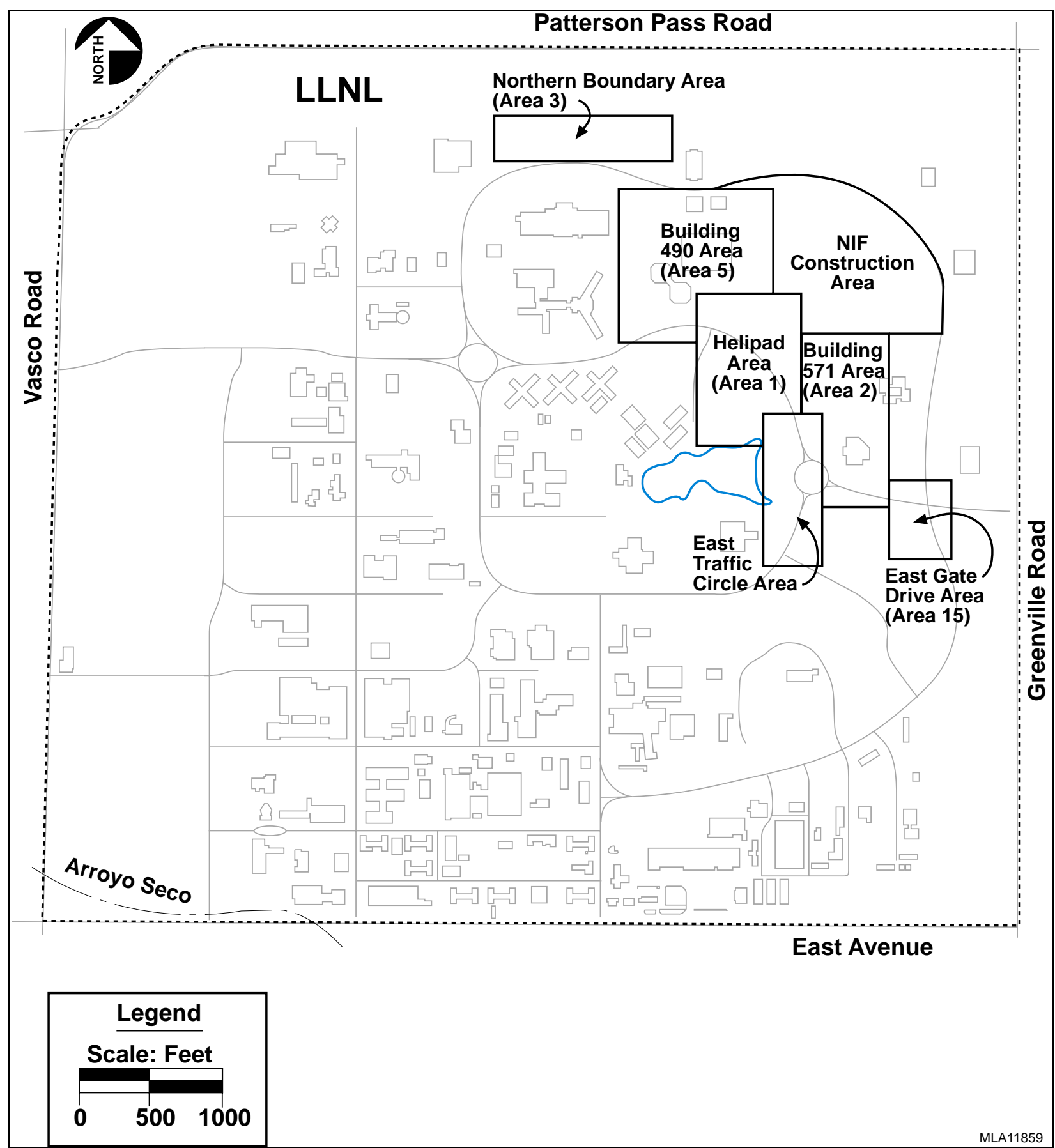

FIGURE 1.1 Areas Identified for Further Investigation in the Joint Stipulation and Order 
single contiguous block, while the seventh, the Northern Boundary Area, lies a short distance northwest of the main block. The areas identified for investigation in the Joint Stipulation and Order are as follows:

a. Area 1: Helipad Area;

b. Area 2: Building 571 Area;

c. Area 3: Northern Boundary Area;

d. Area 5: Building 490 Area;

e. East Traffic Circle Area;

f. Area 15: East Gate Drive Area; and

g. Area extending from Areas 1,2 and 5 to and including the NIF construction site and beyond to the perimeter of the circular road immediately beyond the NIF construction site, as marked on the map in the Joint Stipulation and Order (in this SEIS this area is called the "NIF Construction Area").

The above designations refer to current uses and are not necessarily linked to any past waste placement activities; waste burial sites are known to have been used within these areas. No past waste placement activities were known in the NIF Construction Area at the time of preparation of the SSM PEIS. Known waste placement locations in the stipulated areas were remediated by the end of 1984, with a CERCLA review completed in 1987. Those locations are as follows:

- The Northern Boundary Area contains a former garbage dump (landfill) used for the disposal of nonhazardous laboratory wastes. The landfill was operated from around 1965 to 1974. (An additional garbage pit from the same or earlier era located along the eastern border of the northeast quadrant is outside the stipulated areas [Dreicer 1985]).

- The East Traffic Circle Area includes a major landfill that was operated from the late 1950s to the early 1980s; some hazardous materials, including PCBs, were placed in the landfill. The East Traffic Circle Landfill (ETCL) was remediated and closed, and the East Traffic Circle was restored in the mid 1980s. As discussed in Section 1.1, soil containing the PCB Aroclor 1254 was excavated from the ETC Area during routine maintenance operations and disposed of under the CERCLA remediation process. 
- The Helipad Area, Building 490 Area, and East Gate Drive Area are currently undergoing groundwater treatment and/or monitoring for volatile organic compound (VOC) contamination from past releases.

\subsubsection{Supplemental Environmental Impact Statement}

The Joint Stipulation and Order also provides for DOE to prepare and circulate for public comment a supplement to the SSM PEIS, in accordance with DOE National Environmental Policy Act (NEPA) regulation 10 CFR 1021.314(d). This SEIS has been prepared to comply with that provision. Paragraph 7 of the Joint Stipulation and Order provides that the SEIS will evaluate "...the reasonably foreseeable significant adverse environmental impacts of continuing to construct and of operating NIF at LLNL, with respect to any potential or confirmed contamination in the area by hazardous, toxic and/or radioactive materials." DOE believes that this requirement of the Joint Stipulation and Order defines the scope of the SEIS.

\subsection{COMMENTS RECEIVED ON THE NOTICE OF INTENT}

DOE received one set of comments, from the U.S. Environmental Protection Agency (EPA), on the September 25, 1998, NOI. The EPA commented that the SEIS scope should include seismic potential, environmental hazards of operating NIF that were not identified in the Joint Stipulation and Order, waste streams and waste management from operations, and permitting and regulatory approval. DOE has considered these comments and has addressed them in a manner consistent with the scope of the SEIS, i.e., whether they bear on the question of contamination by hazardous, toxic, or radioactive materials in the area of NIF. However, DOE does not believe that it is appropriate to expand the scope beyond that established by the Joint Stipulation and Order. DOE agreed to conduct the characterization activities described above and to prepare the SEIS in response to the discovery of the buried capacitors during the construction of NIF. No other new information has been developed that would call into question the analysis and conclusions contained in the SSM PEIS, and the NIF PSA contained therein, regarding the environmental impacts of constructing and operating NIF.

Although DOE believes that the Joint Stipulation and Order establishes the appropriate scope of the SEIS, careful consideration was given to EPA's comments. The responses to those comments, which are paraphrased in italics below, are as follows:

- A clear statement of purpose and need was requested. DOE believes that the Joint Stipulation and Order established the purpose and need for the SEIS. The purpose and need for NIF are contained in the SSM PEIS (DOE 1996a, Appendix I) and are incorporated by reference and briefly described in Section 1.2 of this SEIS. 
- A concise summary of the history of the project and events leading to this SEIS was requested. Section 1 (including Section 1.1) of this SEIS provides the history of events leading to this SEIS.

- A summary of the various elements of the NIF facility was requested. A brief description of NIF is found in Section 1. The various elements of NIF are summarized in Appendix I of the SSM PEIS. Since the purpose and need for the SEIS are determined by the Joint Stipulation and Order, the requirements specified in this agreement are the focus of this SEIS. Further description of the NIF is not provided in order for the document to remain focused on the required investigations and the impacts of any soil or water contamination as a result of previously undiscovered buried materials.

- A request was made to post the SSM PEIS and ROD on the World Wide Web and to reference the Uniform Resource Location (URL) on the abstract page. The summary SSM PEIS is found at the following URL: http://www.nepa.eh.doe.gov/eis/nometa/eis0236/toc.htm. The ROD can be found at http://www.tis.eh.doe.gov/nepa/docs/rods/1996/index.htm.

- Full results of all field examinations and remediation activities should be summarized. Section 4 summarizes in detail the results of field investigations and describes whether residual contamination remains after completion of cleanup activities. Further detail is contained in the quarterly reports prepared as required by the Joint Stipulation and Order.

- Include the environmental hazards of operating NIF. This information is included in the SSM PEIS (Appendix I). The environmental hazards of operating NIF are not part of the Joint Stipulation and Order.

- Include the most current East Bay seismic potential in the SEIS. The affected environment section of this SEIS includes geologic information, including seismic potential.

- Expected and potential waste streams from routine operations should be described. This issue is discussed in the SSM PEIS (Appendix I). The waste streams generated during NIF operations are not part of the Joint Stipulation and Order. The scope of the SEIS is limited to buried wastes and contamination from past site operations.

- DOE should examine its final purpose and need and the reason for the proposed action. The purpose and need for NIF continues as stated in the SSM PEIS. A brief statement of purpose and need is contained in Section 1.2. 
- DOE should provide recommendations, where appropriate, as to how the ongoing project could be modified to most adequately mitigate any potential for adverse impacts. Section 4 of this SEIS includes an analysis of whether any hazardous materials discovered during the characterization studies under the Joint Stipulation and Order would have impacts on human health or the environment. No impacts were discovered that would require further mitigation.

- A cumulative impact discussion should be added. Section 4.4 discusses cumulative impacts.

- Recommend that the SEIS contain a listing of various permits and other approvals required for construction and operations, including the name of the permit and the issuing agency. This SEIS identifies the regulatory framework of activities conducted under the Joint Stipulation and Order. In general, regulatory requirements for the construction and operation of NIF are covered in the SSM PEIS (DOE 1996a, Appendix I). 
[This page intentionally left blank.] 


\section{PROPOSED ACTION AND ALTERNATIVES}

DOE's proposed action is to continue to construct and, ultimately, to operate NIF, as decided in the ROD for the SSM PEIS. The SSM PEIS, the NIF PSA (DOE 1996a), and the technology basis report (DOE 1996b) analyzed five site alternatives and two design options (indirect and direct drive) for NIF. Those alternatives and options are not revisited in this SEIS. Instead, this SEIS examines continuing construction and operation of NIF in light of recently discovered PCB wastes in the NIF Construction Area and residual PCB contamination in the ETC Area. This SEIS also presented the results of the characterization studies that DOE conducted and completed in 1998 and 1999 pursuant to the Joint Stipulation and Order.

\subsection{NO ACTION ALTERNATIVE}

The Council on Environmental Quality (CEQ) regulations implementing the National Environmental Policy Act (NEPA) require that an EIS consider a no action alternative (40 CFR 1502.14(d)). DOE has examined the no action alternative from two perspectives. The first defines no action as the ongoing activity of continuing to construct and operate NIF. The second assumes that DOE would cancel the NIF project, ceasing construction and making the site usable for another purpose. Section 4.2 describes the consequences of continuing to construct and operate the NIF. Section 4.3 describes the consequences of ceasing NIF construction.

\subsubsection{No Action as an Ongoing Activity (DOE's Preferred Alternative)}

CEQ has indicated that, in the case of ongoing activities, the no action alternative represents the status quo. ("[T]he 'no action' alternative may be thought of in terms of continuing with the present course of action until that action is changed" [Forty Most Asked Questions Concerning CEQ's NEPA Regulations, Question 3, 46 FR 18026, 18027 (March 23, 1981)].)

DOE's current action to construct and operate NIF, as proposed and analyzed in the NIF PSA of the SSM PEIS, represents the status quo. Under this interpretation of the no action alternative, DOE would make no changes in the design of NIF, would undertake no deviations in construction techniques, and would impose no operational changes in response to the information regarding site contamination obtained during the characterization studies completed pursuant to the Joint Stipulation and Order. 


\subsubsection{No Action as Ceasing Construction of NIF at LLNL}

Because no action could also be interpreted as "no project at LLNL," DOE has also included this construct of no action in this SEIS. A decision to stop constructing NIF at LLNL could result either in a decision to construct and operate the facility at another site or in a decision to cancel the project entirely. The impacts of constructing and operating NIF at other sites and of not constructing or operating the facility at LLNL were analyzed in detail in the SSM SEIS, the NIF PSA, and the technical basis and site comparison report (DOE 1996b). The impacts of cleaning up PCB contamination at the present site are discussed in this SEIS.

DOE believes that "no action" when defined as ceasing construction of NIF is not a reasonable alternative. Moving NIF to another site would be reasonable to consider only if the characterization studies had determined that the contamination caused by buried hazardous, toxic, or radioactive materials was so extensive as to raise serious questions about the advisability of continuing the project in its current location. This is not the case, since, as summarized below in Section 2.3 and discussed in detail in Chapter 4, no new contamination was found. Canceling the project would be reasonable to consider only if the DOE's purpose and need has changed so that NIF is no longer required. This also is not the case. However, to provide a comparison, the impacts of ceasing construction are briefly analyzed in Section 4.3.

The conventional construction of the NIF facility is now approximately $80 \%$ complete, and moving NIF to another site at this time would have significant economic and programmatic consequences (DOE 1996b) and is unnecessary considering the results of Phase I and Phase II characterization activities. The NIF requires large-scale laser research, development, and support facilities that are present only at LLNL. These requirements for scientific infrastructure for NIF would have to be established at another site if NIF were moved.

As highlighted in Section 2.3 and discussed in Chapter 4, no additional previously unknown or undiscovered sources of contaminated objects were found at the NIF Construction Area as a result of Phase I and Phase II characterization activities, including magnetometer survey (SPPORTS 1997, 1998a-b), and the impacts of cleanup were minor - below levels of concern for human health. The residual contamination found at the ETC Area is not in the area of NIF and would not affect NIF construction or operation. Magnetometer surveys did not identify any contaminated objects in the ETC (SPPORTS 1999), and the site was cleaned up to EPA Region 9 Preliminary Remediation Goals (PRGs) for an industrial site (Bainer 1999). The impacts analyzed in this SEIS pertaining to cleanup of wastes or residual contamination apply to both alternatives of continuing to construct NIF and to cease NIF construction. Section 4.3 briefly describes the impacts of ceasing NIF construction. 


\subsection{ACTION ALTERNATIVES (ELIMINATED FROM DETAILED STUDY)}

The CEQ regulations also require that an EIS analyze all reasonable alternatives to the proposed action and discuss the reasons why other alternatives were eliminated from detailed study [40 CFR 1502.14(a)]. As stated by CEQ: "[w]hat constitutes a reasonable range of alternatives depends on the nature of the proposal and the facts in each case" (Forty Most Asked Questions, Question 1, 46 FR 18027). As discussed below, DOE believes that the facts surrounding the proposed action and purpose and need for this SEIS lead to the conclusion that there are no reasonable action alternatives under the circumstances, and, therefore, that all action alternatives should be eliminated from detailed study.

Possible action alternatives would consist of various ways to modify the manner in which DOE continues to construct and operate the facility to take into account the results of the characterization studies. These modifications could include changes in the design or changes in the manner of constructing or operating the facility to avoid releasing contamination, as well as modifications in the construction schedule to allow any contamination that was discovered to be remediated before proceeding.

This group of alternatives would be reasonable to consider only if the characterization studies concluded that there are additional buried hazardous, toxic, or radioactive materials or soils in the area of the NIF construction site that would adversely impact human health and the environment. Phase I and II evaluations of the NIF site pursuant to the Joint Stipulation and Order have uncovered no positive indications of hazardous, toxic, and/or radioactive material. The hazardous materials discovered during NIF construction have already been cleaned up. These materials are now below levels of concern for impacts to the environment or human health. Characterization studies have shown that there is a very low likelihood of further discovery of any buried wastes. Further NIF construction and NIF operations would not result in potential health impacts to workers or the public from hazardous, toxic, or radiological materials related to buried wastes. Therefore, no design, construction, or operation modifications to address the presence of such materials need be considered. Any contaminants within the area defined in the Joint Stipulation and Order, and outside the NIF construction site, will be addressed under the CERCLA process with CERCLA RPM oversight.

\subsection{SUMMARY OF IMPACTS}

This SEIS summarizes Phase I and Phase II characterization studies (see Section 4) and evaluates the potential impacts (including cumulative impacts) to LLNL workers and to the public from construction and operation of the NIF because of the possible presence of buried hazardous, toxic, or radioactive materials in the areas in the northeastern quadrant of the LLNL as stipulated in the Joint Stipulation and Order. 
Results of Phase I and Phase II investigations show that there is a low likelihood that significant quantities of buried hazardous, toxic, or radioactive materials remain in the stipulated areas. On the basis of these findings, DOE has concluded that the only source of buried materials in the NIF Construction Area was the capacitor landfill discovered in September 1997 and subsequently cleaned up. PCB-contaminated soils recently discovered during maintenance work in the ETC Area are believed to represent residual contamination from capacitors previously excavated during the ETCL closure in 1984 (DOE 1999b).

DOE's analysis of new information regarding soil and groundwater contamination concluded that levels of contamination are well below those that would impact human health. Soil contamination does not present a risk of adverse health effects to workers from respiration of dust. Remedial actions addressing PCB-contaminated soil in the NIF Construction Area and in the ETC Area achieved cleanup criteria determined by applicable guidelines and approved by the RPMs to be protective of human health and the environment. Analyses of potential health impacts to a hypothetical maximally exposed member of the public from dust-borne PCBs potentially generated during these actions found potential exposures to be well below levels of concern $\left(1 \times 10^{-6}\right.$ cancer risk or 1.0 hazard quotient for noncancer impacts). Protection of groundwater by soil cleanup levels achieved in the two areas was verified through groundwater sampling and modeling analysis. Levels of PCB contamination in groundwater now and projected into the future are calculated to be well below levels considered to present a risk to the public. Construction and operation of NIF would not directly adversely affect groundwater because no groundwater withdrawals or discharges would occur from this facility. Ongoing remediation activities will continue to improve groundwater quality for both the no action alternatives - (1) continuing construction and operation of NIF and (2) ceasing construction of NIF. Potential impacts on the human environment at LLNL are below any level of significance.

The impacts of ceasing NIF construction would depend on whether (1) the facility would be completed and used for another purpose or (2) the facility would be demolished and the site returned to a brownfield condition. For either of these options, employment at LLNL would decline, and reduced employment would have an adverse socioeconomic impact in the TriValley area. Demolishing the NIF buildings would increase exposure of workers to occupational hazards. The transportation of an estimated 4,400 $\mathrm{m}^{3}\left(5,800 \mathrm{yd}^{3}\right)$ of nonhazardous wastes off-site and delivery of fill for excavated areas would increase truck traffic, potentially impacting nesting white-tailed kites and increasing the risk of transportation accidents. If the building were reused for another purpose, doses from radionuclides and hazardous materials would remain as assessed for NIF and LLNL. If the NIF facility were demolished, risk from radionuclides and hazardous materials associated with the facility would be absent. Demolition would result in release of dusts (including $\mathrm{PM}_{10}$ ); the LLNL area is not in attainment for this criteria pollutant. Demolition might further disturb paleontological resources that were left in place during NIF construction. 


\section{AFFECTED ENVIRONMENT}

Section 3 describes the aspects of the LLNL environment pertinent to the issues evaluated in this SEIS. Topics included are geology, soils, water use, surface water, hydrogeology, soil and groundwater quality, and ongoing remediation activities.

\subsection{GEOLOGY}

The Livermore Site is located within the California Coast Ranges, an area of northnorthwest trending ranges and valleys. Livermore Valley forms an east-west structural basin defined by branches of the San Andreas Fault system. The site occupies a smooth land surface that slopes gently to the northwest.

The site is underlain by late Tertiary and Quaternary rocks that lie on basement rocks of the Franciscan assemblage, which consists of severely deformed sandstone, shale, and chert. In the area of Livermore, this unit is composed primarily of sandstone. The basin is filled with 1,219 m (4,000 ft) of Pliocene to Holocene alluvial gravels, sands, and lacustrine clays. Late Quaternary alluvial deposits immediately underlie the site.

The historically active, northwest-trending Calaveras fault zone (the easternmost branch of the San Andreas fault system in the San Francisco Bay area) traverses the western margin of Livermore Valley. The Concord-Green Valley fault and parallel-trending Greenville fault zone define the eastern boundary of the valley. Two other capable faults (Las Positas and Verona), as well as several inactive faults, cut the southern part of the valley. The Livermore Site lies in an area of historically inactive faulting $(1.6 \mathrm{~km}$ [1.0 mi] north of the Las Positas fault zone and less than $3.2 \mathrm{~km}$ [2.0 mi] west of the Greenville fault zone [DOE 1996]). The Calaveras fault has had several earthquakes of Richter magnitude 5.0 or greater in the last 150 years. A maximum probable earthquake having a magnitude greater than 7.0 in the LLNL area is possible. Additional details on recent seismic activity are summarized in DOE (1996).

\subsection{SOILS}

The Livermore Site is located on soils originally classified as the Rincon-San Ysidro association. These soils are nearly level and have a loamy texture. They range from shallow to very deep, older fans and floodplains. The erosion hazard of these soils is slight to moderate. Several of these soils, including the Rincon, San Ysidro, and Zamora series, have moderate to high shrink-swell potential. Recently, the area around the Livermore Site has been reclassified as urban and built-up land. No prime or unique farmland soils are located at the site. 


\subsection{WATER USE}

The Livermore area relies on groundwater and imported surface water for its municipal, commercial, residential, and agricultural uses. The water from municipal supply wells is blended with imported surface water before distribution to the public. A small amount of treated groundwater is used to supplement irrigation and cooling tower makeup at LLNL (LLNL 1998).

The total annual water use at the Livermore Site is currently 968 million L/yr (256 million gal/yr) (LLNL 1998). LLNL receives this water from two suppliers. During the summer, deliveries are taken primarily from the Alameda County Flood Control and Water Quality Conservation District Zone 7. This water is a mixture of groundwater and water from the South Bay Aqueduct of the State Water Project. For the remainder of the year, water is usually supplied from the Hetch-Hetchy Aqueduct.

\subsection{SURFACE WATER}

The main surface water features at the Livermore Site are the Arroyo Las Positas and Arroyo Seco (Figure 3.1). Arroyo Las Positas drains the hills directly east of the site and usually flows only after a storm, except locally at the site from the discharge of treated groundwater. This arroyo enters the Livermore Site from the east, is diverted along a storm ditch around the northern edge of the site, and exits at the northwestern corner. Arroyo Seco flows though the southwestern corner of the site. Arroyo Las Positas flows into Arroyo Seco west of the site. Both channels may be dry for part of the year. Nearly all surface water runoff at the Livermore Site is discharged into Arroyo Las Positas. Only surface water runoff along the southern boundary and some storm drains in the southwestern corner of the site drain into Arroyo Seco.

Off-site surface waters near the Livermore Site are routinely monitored for radioactive parameters. In addition, stormwater runoff from the site is monitored for radioactive and nonradioactive parameters. About $25 \%$ of the stormwater within the site drains into the lined Central Drainage Retention Basin; the remainder drains either directly, or via a system of storm sewers and ditches, into Arroyo Seco or Arroyo Las Positas.

Approximately 400 million L (106 million gal) of wastewater from the Livermore Site is discharged to the City of Livermore sewer system annually and processed at the Livermore Water Reclamation Plant (LLNL 1998). This wastewater includes sanitary and industrial discharges from the site and from Sandia National Laboratories, Livermore. The discharges are permitted by the City of Livermore and monitored for $\mathrm{pH}$, selected metals, and radioactivity. 


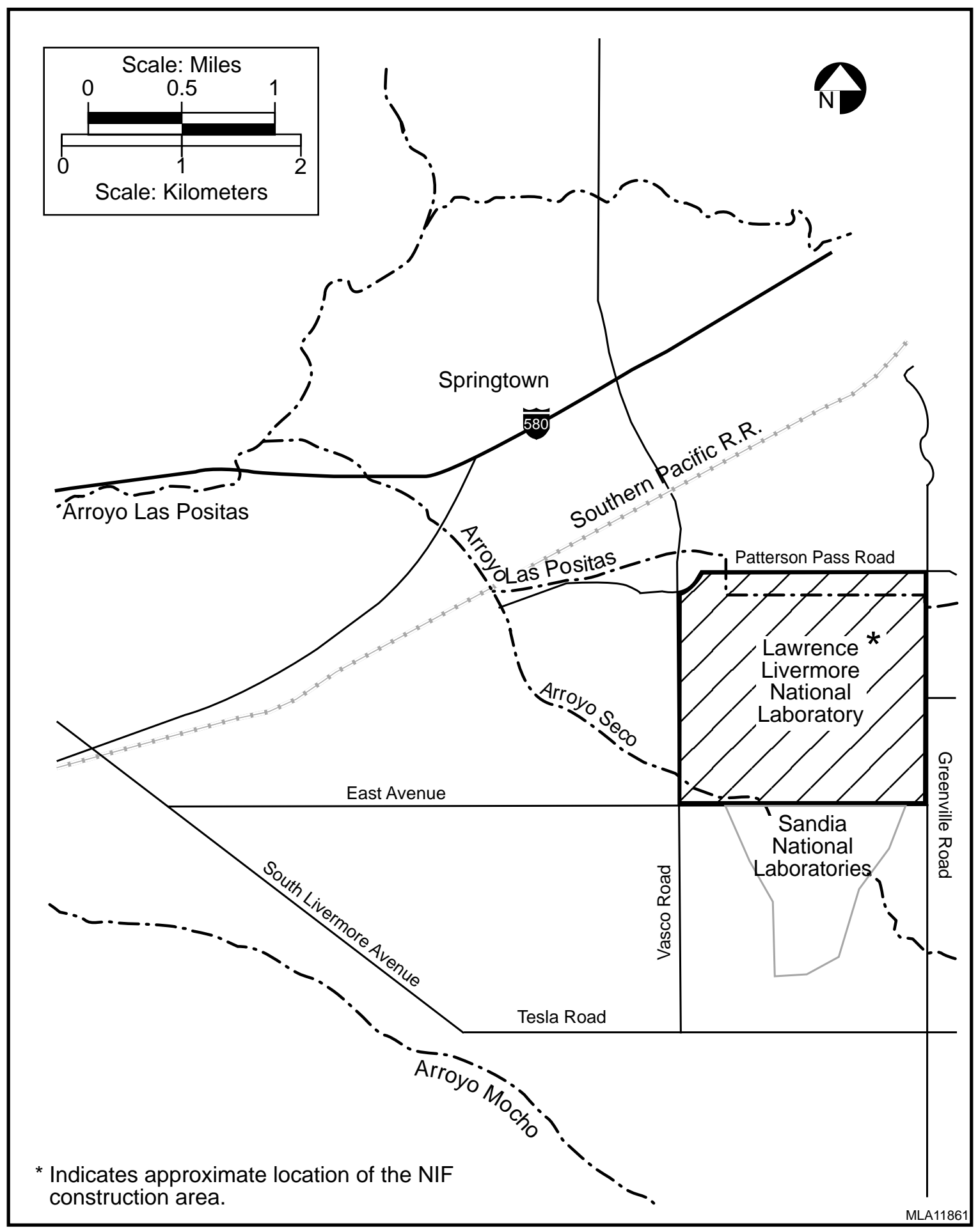

FIGURE 3.1 Surface Water Features near Lawrence Livermore National Laboratory 


\subsection{HYDROGEOLOGY}

Groundwater at the Livermore Site occurs in an upper unconfined zone overlaying a series of semiconfined aquifers. The two geological units containing the most important aquifers are the surface valley-fill deposits (shallow alluvial aquifer) and the Livermore Formation, which is semiconfined. These aquifers are locally recharged by stream runoff from precipitation and controlled releases from the South Bay Aqueduct, direct rainfall infiltration, irrigation, and treated groundwater infiltration. In addition, stream channels, ditches, and gravel pits west of the City of Livermore also recharge the shallow groundwater. Recharge to the uppermost groundwater aquifer occurs primarily through infiltration of precipitation. Vogele et al. (1996) estimate that about $10 \%$ of the precipitation $(33.8 \mathrm{~mm} / \mathrm{yr}$ [1.33 in./yr]) recharges the shallow groundwater in the Livermore Valley.

Conceptually, groundwater near the NIF site has been characterized using six distinct hydrostratigraphic units (HSUs) (LLNL 1994a) (Figure 3.2). An HSU is defined by grouping sediments in close proximity that have similar hydraulic properties. Beneath the Livermore Site,

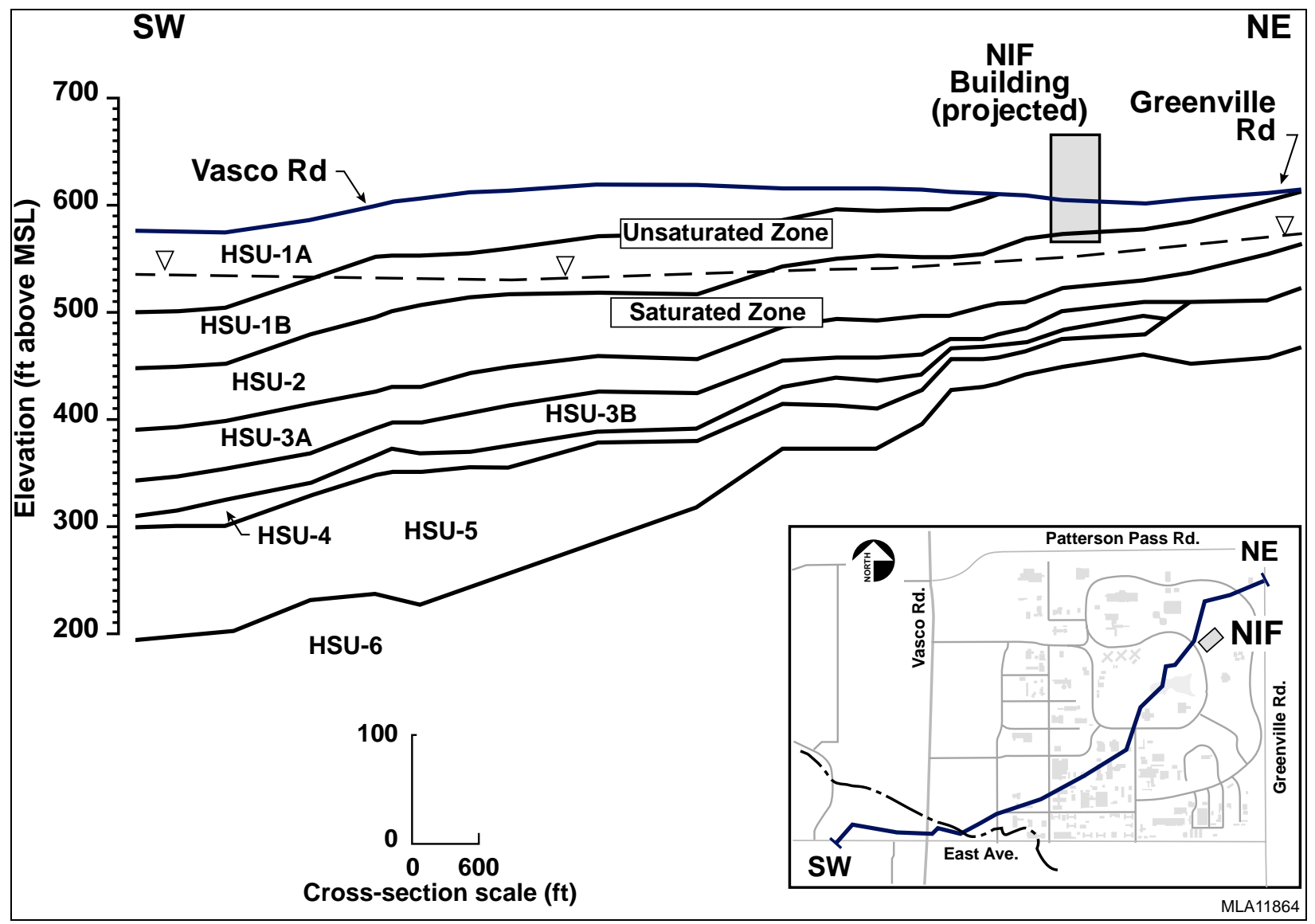

FIGURE 3.2 Generalized Cross Section Showing Hydrostratigraphic Units beneath the Livermore Site 
HSU 1 is a 9- to $15-\mathrm{m}$ (30- to 50-ft) thick interval of interbedded sand, silt, and gravel. HSU 1 is divided into two subunits, HSU 1A and HSU 1B. As shown in Figure 3.2, HSU 1B is unsaturated near the NIF and is the primary unit of interest for this study.

HSU 2 is about $14 \mathrm{~m} \mathrm{(45} \mathrm{ft)} \mathrm{thick} \mathrm{in} \mathrm{the} \mathrm{vicinity} \mathrm{of} \mathrm{the} \mathrm{NIF} \mathrm{site.} \mathrm{HSU} 2$ consists of lowpermeability clayey silt, silty clay, and clayey sand with interbeds of sand and sandy gravel (LLNL 1994a). In portions of the NIF site, this is the first unit that is saturated. No perched water was found in the vicinity of the NIF by groundwater investigations conducted pursuant to the Joint Stipulation and Order.

As with HSU 1, HSU 3 is divided into two subunits: HSU 3A and HSU 3B. HSU 3B consists of low-permeability silt and clay in the northeastern portion of the Livermore Site. In the vicinity of the NIF site, HSU 3A is composed of silty clay, clayey silt, and sand. In this area, the coarser-grained interbeds are thin, discontinuous, and separated by finer-grained sediments.

In the area of the NIF site, HSU 4 is made up of lower permeability silt and clay, or consists of a laterally continuous, high-permeability, sand and gravel unit. It ranges in thickness from about 0.6 to $7.6 \mathrm{~m}$ ( 2 to $25 \mathrm{ft}$ ) (LLNL 1994a) and thins to the east.

HSU 5 is the uppermost part of the Lower Member of the Livermore Formation (LLNL 1994a). This unit is about 7-18 $\mathrm{m} \mathrm{(23-60} \mathrm{ft)} \mathrm{thick} \mathrm{in} \mathrm{the} \mathrm{vicinity} \mathrm{of} \mathrm{the} \mathrm{NIF} \mathrm{site.} \mathrm{The} \mathrm{unit} \mathrm{consists}$ of sand and gravel with interbedded silt and clay.

The upper portion of HSU 6 consists of silty clay to clayey silt, with minor interbeds of clayey sand and gravel. HSU 6 also lies within the Lower Member of the Livermore Formation.

The average groundwater flow velocity beneath the Livermore Site is about $1 \mathrm{~m} / \mathrm{yr}$ (3.3 ft/yr) (Vogele et al. 1996), but varies across the site and within separate HSUs. Analysis of 18 soil samples from the vicinity of the NIF (Stephens and Associates 1996) indicates that the saturated hydraulic conductivity of the soil is variable, ranging from $5.7 \times 10^{-8} \mathrm{~cm} / \mathrm{s}$ $\left(1.6 \times 10^{-4} \mathrm{ft} / \mathrm{d}\right)$ in clayey silt to $0.018 \mathrm{~cm} / \mathrm{s}(51 \mathrm{ft} / \mathrm{d})$ in gravelly sand. The average saturated hydraulic conductivity is approximately $8.3 \times 10^{-3} \mathrm{~cm} / \mathrm{s}(23.4 \mathrm{ft} / \mathrm{d})$ assuming a $\log$ normal distribution of conductivities. Hydraulic conductivity is a parameter that indicates the ease with which water will flow through a porous medium; higher conductivities allow more rapid flow. 


\subsection{SOIL AND GROUNDWATER QUALITY}

\subsubsection{Contaminants}

Initial releases of hazardous materials occurred at the Livermore Site in the mid- to late1940s, when the facility was the Livermore Naval Air Station (Berg et al. 1997). Evidence exists that localized spills, leaking tanks and impoundments, and landfills contributed volatile organic compounds (VOCs) (organic compounds that readily vaporize), fuel hydrocarbons (FHCs) (e.g., benzene, toluene, ethylbenzene, and xylene [BTEX]), and tritium to the groundwater and soils in the post-Navy era. Because of this contamination, the Livermore Site was placed on the EPA's National Priorities List in 1987. Approximately 450 wells are monitored regularly at Livermore Site to assess groundwater quality. Wells in the vicinity of the study areas are shown in Figure 3.3. In general, contaminant concentrations have decreased from historic maximums because of remediation activities.

Contaminants present at the Livermore Site at concentrations above their regulatory maximum contaminant levels (MCLs) in the groundwater include VOCs and FHCs. Tritium is also present in groundwater. LLNL is actively remediating such contamination, as appropriate, under CERCLA. The following specific contaminants for which monitoring data are available are reported in this SEIS:

- VOCs: trichloroethylene (TCE), perchloroethylene (PCE), trichlorofluoromethane (Freon 11), and carbon tetrachloride;

- Radionuclides: tritium.

The Livermore Site has an extensive subsurface monitoring program. Since 1986, an integrated sample and data management program has supported the collection, validation, interpretation, and use of the soil and groundwater data. A highly concentrated monitoring network within the $1-\mathrm{mi}^{2}$ Livermore Site consists of more than 1,000 boreholes and approximately 450 regularly monitored wells.

The following subsections summarize the results of historical and current soil and groundwater monitoring for each of the areas defined in the Joint Stipulation and Order: the Helipad Area, Building 571 Area, Northern Boundary Area, Building 490 Area, East Traffic Circle Area, East Gate Drive Area, and the NIF Construction Area. Additional details on existing groundwater quality can be found in the Action Memorandum (Bainer and Berg 1998). Summaries of soil and water quality parameters are given in Tables 3.1 and 3.2 for the stipulated areas. Table 3.1 gives maximum sampled soil sediment concentrations in each area for each of 


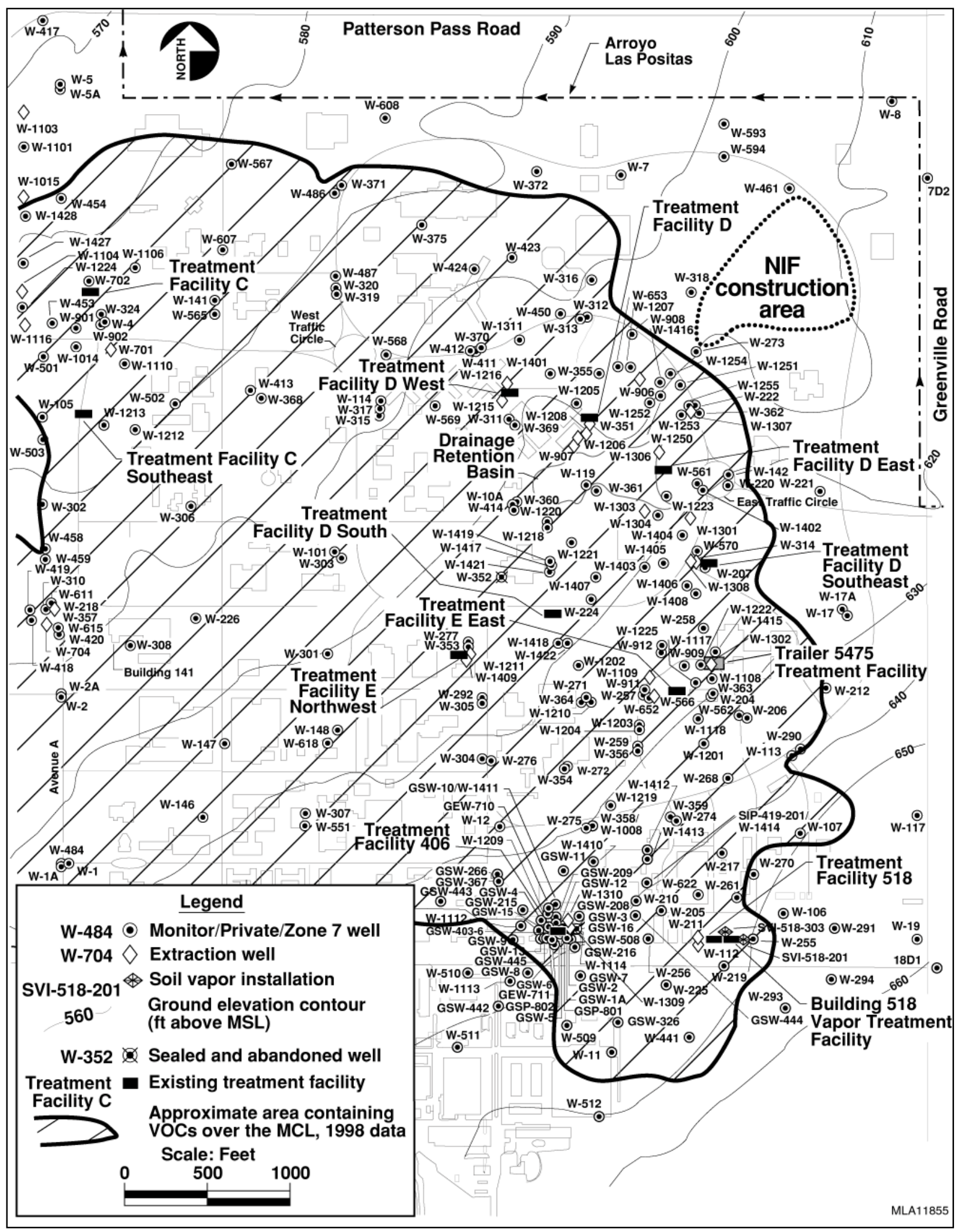

FIGURE 3.3 Eastern Portion of the Livermore Site Showing Groundwater Wells and Approximate Area Containing VOCs over the Maximum Contaminant Levels in 1998 
TABLE 3.1 Compilation of Historic Maximum Analyte Concentrations in Soil/Sediments for the Seven Study Areas

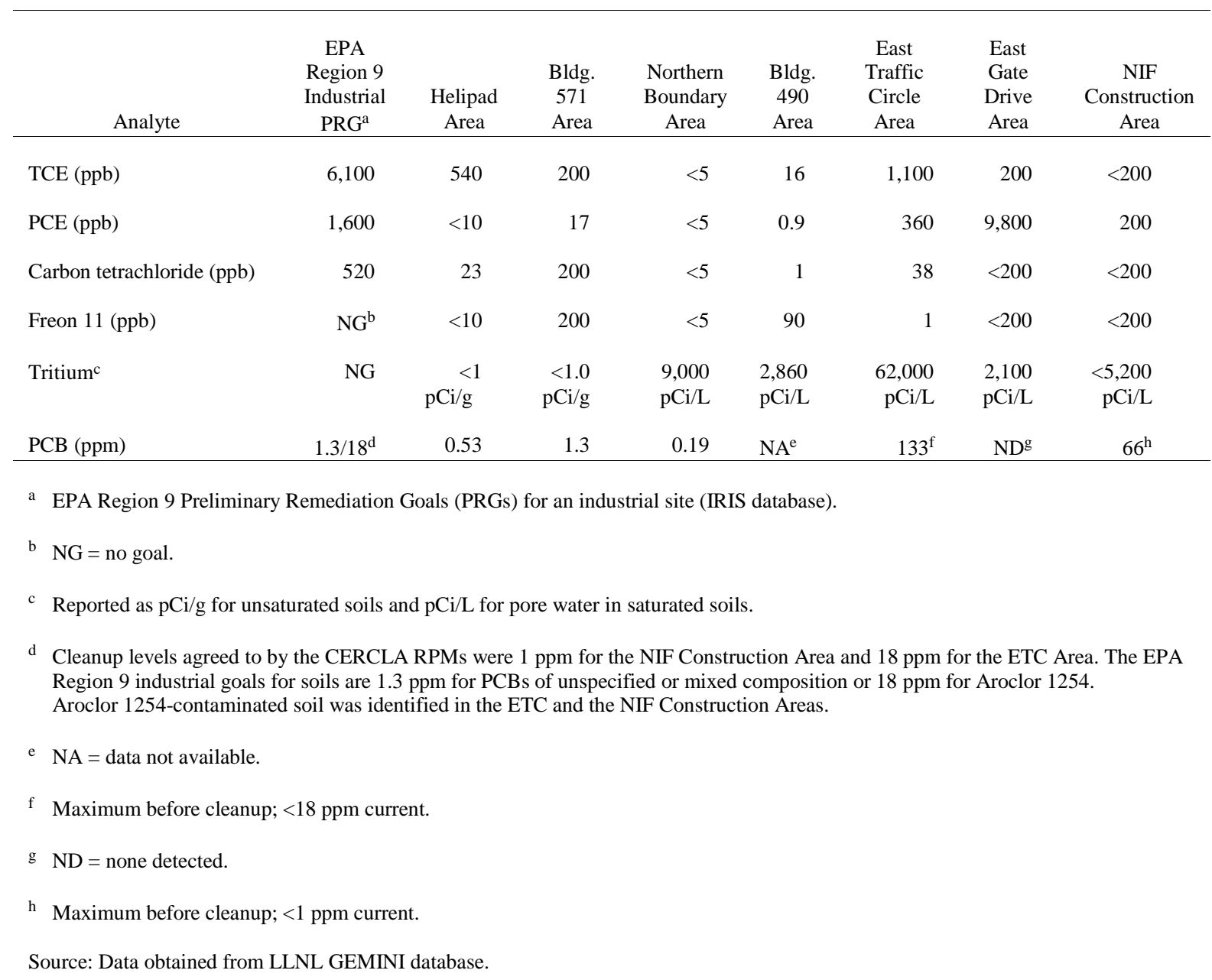

seven contaminants. Values in these tables were obtained from the LLNL GEMINI database. These six contaminants were selected for the tables because of their widespread presence at the site and the availability of concentration data. An examination of Table 3.2, which includes both historic and current data, indicates that, in general, contaminant concentrations have decreased below historical maximum concentrations because of remediation activities that are taking place. A more complete evaluation and comparison of current concentrations to historic maximums and values in 1997 has been developed by Tomasko and Quinn (1999).

All results reported in the following subsections are expressed as concentrations based on measures of weight per unit volume for groundwater or weight per unit weight for soils 
TABLE 3.2 Compilation of Historic Maximum, 1997, and Current Analyte Concentrations in Groundwater Samples from the Seven Study Areas

\begin{tabular}{|c|c|c|c|c|c|c|c|c|}
\hline Analyte & $\begin{array}{c}\text { California } \\
\text { MCL }^{\mathrm{a}}\end{array}$ & $\begin{array}{c}\text { Helipad } \\
\text { Area }\end{array}$ & $\begin{array}{c}\text { Bldg. } \\
571 \\
\text { Area } \\
\end{array}$ & $\begin{array}{c}\text { Northern } \\
\text { Boundary } \\
\text { Area }\end{array}$ & $\begin{array}{c}\text { Bldg. } \\
490 \\
\text { Area } \\
\end{array}$ & $\begin{array}{c}\text { East } \\
\text { Traffic } \\
\text { Circle } \\
\text { Area } \\
\end{array}$ & $\begin{array}{c}\text { East } \\
\text { Gate } \\
\text { Drive } \\
\text { Area }\end{array}$ & $\begin{array}{c}\text { NIF } \\
\text { Construction } \\
\text { Area } \\
\end{array}$ \\
\hline TCE (ppb) & 5 & & & & & & & \\
\hline Historic Maximum & & 13,000 & 48 & 11.0 & 45 & 1,600 & 1.3 & 16 \\
\hline 1997 & & 1,800 & $\mathrm{NA}^{\mathrm{b}}$ & $<0.5$ & $<2.5$ & 760 & $<0.5$ & $<0.5$ \\
\hline Current & & 1,900 & NA & $<0.5$ & $<2.5$ & 550 & NA & NA \\
\hline PCE (ppb) & 5 & & & & & & & \\
\hline Historic Maximum & & $<100$ & 2.4 & $<5$ & $<50$ & 1,600 & $<1.0$ & 0.7 \\
\hline 1997 & & 32 & NA & $<0.5$ & $<2.5$ & 1,600 & $<0.5$ & $<0.5$ \\
\hline Current & & 73 & NA & 0.54 & $<2.5$ & 1,000 & NA & NA \\
\hline Carbon tetrachloride (ppb) & 0.5 & & & & & & & \\
\hline Historic Maximum & & 230 & 10 & $<5.0$ & $<50$ & 120 & $<1.0$ & 1.5 \\
\hline 1997 & & 51 & NA & $<0.5$ & $<2.5$ & $<2.5$ & $<0.5$ & $<0.5$ \\
\hline Current & & 54 & NA & $<0.5$ & 0.9 & $<2.5$ & NA & NA \\
\hline Freon $11(\mathrm{ppb})$ & $\mathrm{NG}^{\mathrm{c}}$ & & & & & & & \\
\hline Historic Maximum & & $<100$ & NA & 250 & 1,400 & $<50$ & $<1.0$ & 1.0 \\
\hline 1997 & & $<5$ & NA & 250 & 480 & $<2.5$ & $<0.5$ & $<0.5$ \\
\hline Current & & $<5$ & NA & 150 & 360 & $<2.5$ & NA & NA \\
\hline Tritium (pCi/L) & 20,000 & & & & & & & \\
\hline Historic Maximum & & $<1,000$ & 900 & 800 & NA & $<1,000$ & $<1,000$ & $<1,000$ \\
\hline 1997 & & NA & NA & 800 & 248 & NA & $<35$ & NA \\
\hline Current & & 133 & NA & NA & NA & NA & 79 & NA \\
\hline PCB (ppm) & 0.0005 & & & & & & & \\
\hline Historic Maximum & & NA & $\mathrm{ND}^{\mathrm{d}}$ & ND & NA & ND & ND & ND \\
\hline 1997 & & NA & NA & NA & NA & NA & NA & NA \\
\hline Current & & NA & $\mathrm{ND}$ & ND & NA & ND & ND & ND \\
\hline \multicolumn{9}{|c|}{${ }^{\mathrm{a}} \mathrm{MCL}=$ Maximum Contaminant Level. } \\
\hline \multicolumn{9}{|l|}{${ }^{\mathrm{b}} \mathrm{NA}=$ data not available. } \\
\hline \multicolumn{9}{|l|}{${ }^{\mathrm{c}} \mathrm{NG}=$ no guideline. } \\
\hline${ }^{\mathrm{d}} \mathrm{ND}=$ none detected. & & & & & & & & \\
\hline
\end{tabular}

(unsaturated sediments ${ }^{1}$ and saturated sediments ${ }^{2}$ ). Standard convention uses different units for groundwater $(\mu \mathrm{g} / \mathrm{L}$ or parts per billion $[\mathrm{ppb}]$, and $\mathrm{mg} / \mathrm{L}$ or parts per millions $[\mathrm{ppm}])$ and soils $(\mu \mathrm{g} / \mathrm{kg}$ or parts per billion [ppb], and $\mu \mathrm{g} / \mathrm{g}$ or parts per million [ppm]). PCB concentrations are in units of ppm for both soils and groundwater; all other concentrations are in units of ppb, except

1 Unsaturated sediment: Sediment between the land surface and the water table that contains water under pressure less than an atmosphere and contains air or gases generally under atmospheric pressure. Unsaturated sediment analytical results are considered to represent residual concentrations from previous releases.

2 Saturated sediment: Sediment with void space filled with liquid. Saturated sediment analytical results are considered to represent a combination of soil and groundwater concentrations. 
tritium is reported as $\mathrm{pCi} / \mathrm{g}$. Applicable standards have also been expressed in the same units as the concentration value for ease of comparison. Concentrations of contaminants in groundwater and soils are compared to action levels consisting of applicable standards and guidelines. Soil concentrations of contaminants are compared in Table 3.1 and in Figures 3.4, 3.6, 3.8, 3.10, 3.12, 3.14, and 3.16 with the EPA Region 9 industrial Preliminary Remedial Goals (PRGs) or cleanup levels agreed to by the RPMs. Groundwater concentrations are compared to the Maximum Contaminant Levels (MCLs) listed in drinking water standards (Table 3.2 and Figures 3.5, 3.7, 3.9, 3.11, 3.13, and 3.15). The PRGs provided in the tables and figures are reference concentrations for comparison with the reported measured concentrations. They are relevant only to areas where cleanup actions have occurred.

\subsubsection{Helipad Area}

Subsurface source investigations performed before October 1997 within the Helipad Area (Figure 1.1) included 85 soil vapor survey (SVS) points, 10 boreholes, and 15 monitor wells. Results of these surveys and those of studies conducted pursuant to the Joint Stipulation and Order are presented in Tables 3.1 (soil) and 3.2 (groundwater) and illustrated graphically in Figures 3.4 and 3.5. Major observations related to contaminants in the Helipad Area are as follows:

- VOCs at concentrations generally below $10 \mathrm{ppb}$ were detected in unsaturated sediments in over half of the boreholes.

- A maximum TCE concentration of $540 \mathrm{ppb}$ occurred in saturated sediments from SIB-HPA-006 in April 1990 (Table 3.1).

- A maximum groundwater TCE concentration of $13,000 \mathrm{ppb}$ occurred in well W-653 in June 1996 (Table 3.2). By August 1998, this concentration had decreased to $1,900 \mathrm{ppb}$ because of extraction from a pump-and-treat well located about $60 \mathrm{~m}(200 \mathrm{ft})$ west of the helipad.

- Tritium was detected in unsaturated sediment samples at a concentration of $<1 \mathrm{pCi} / \mathrm{g}$.

- Gross alpha and gross beta radioactivity were not detected, or were within natural background values, in groundwater collected from monitoring wells screened in HSU 2. Tritium concentrations in groundwater were less than $1,000 \mathrm{pCi} / \mathrm{L}$.

- PCBs at a concentration of $0.53 \mathrm{ppm}$ were detected in unsaturated sediment samples. 


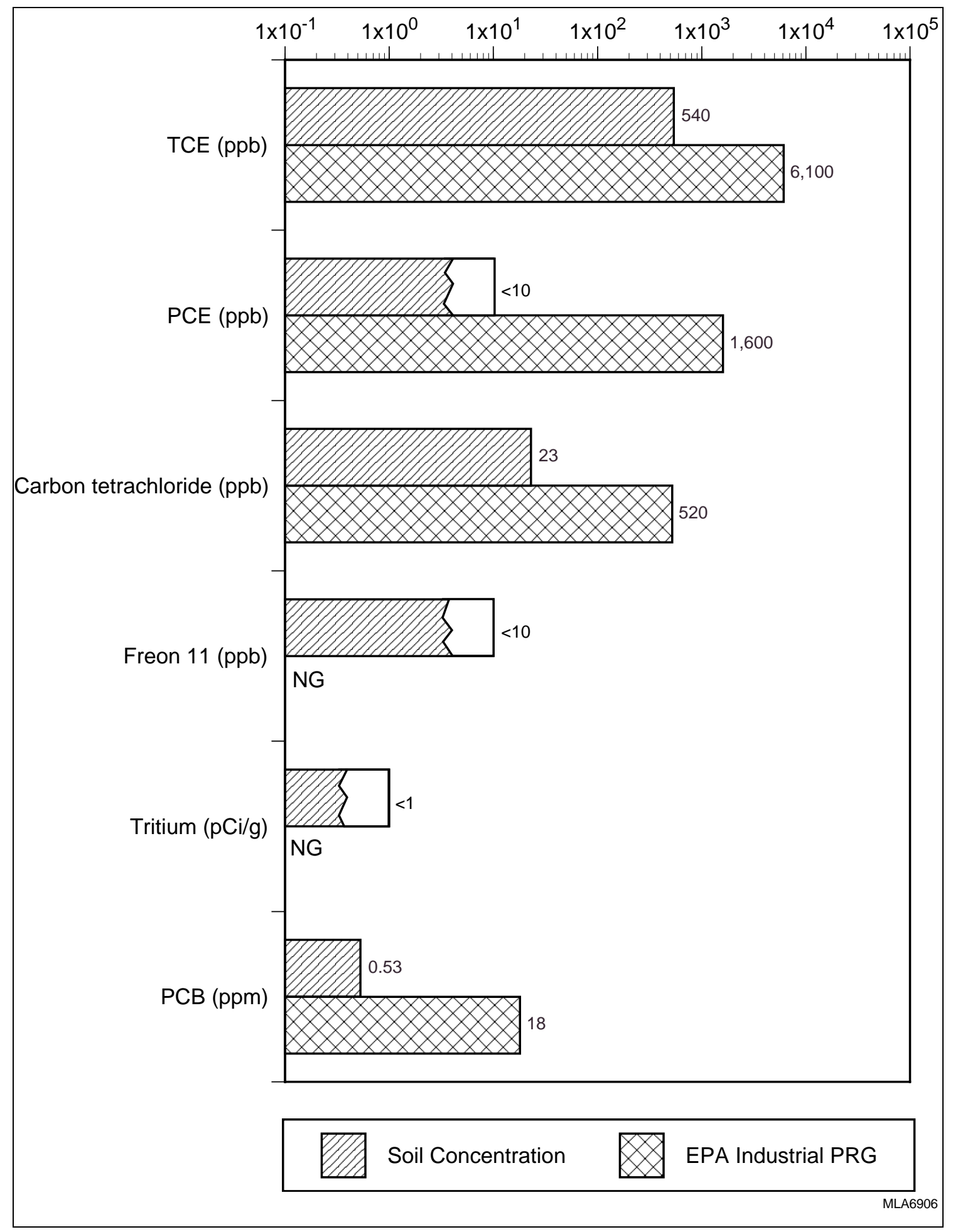

FIGURE 3.4 Soil Concentrations for the Helipad Area and EPA Region 9 Industrial Preliminary Remediation Goals (PRGs) (NA = no data available, ND = none detected, NG = no goal) 


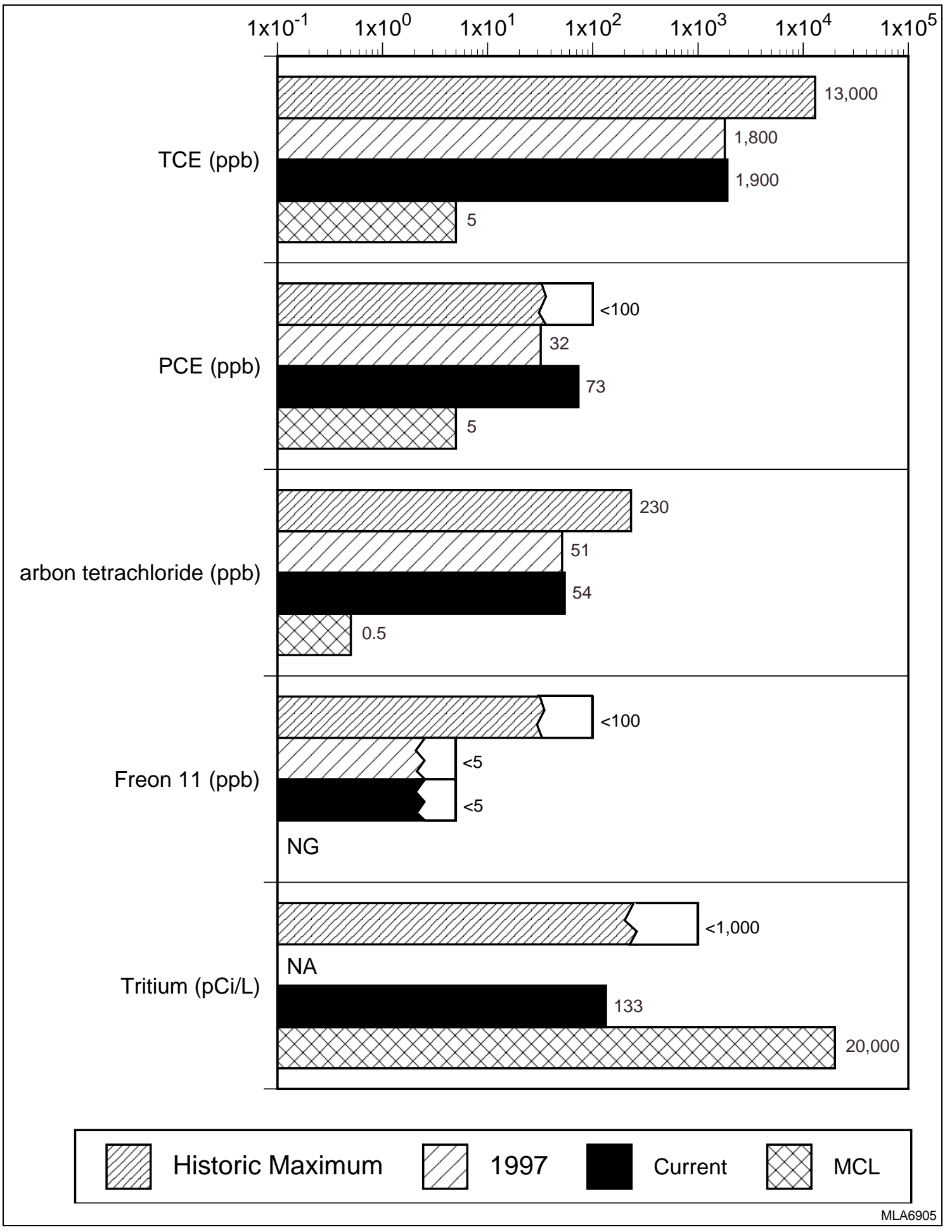

FIGURE 3.5 Groundwater Concentrations for the Helipad Area and Maximum Concentration Limits (MCLs) for Drinking Water (NA = no data available, ND = none detected, $\mathrm{NG}=$ no goal) 


\subsubsection{Building 571 Area}

Subsurface source investigations within the Building 571 Area (Figure 1.1) before October 1997 included 80 SVS points and 10 boreholes. Results of these surveys and those of studies conducted pursuant to the Joint Stipulation and Order are presented in Tables 3.1 (soil) and 3.2 (groundwater) and are illustrated graphically in Figures 3.6 and 3.7. Major observations related to contaminants in the Building 571 Area are as follows:

- VOC concentrations of $200 \mathrm{ppb}$ or less were detected in shallow (less than $6 \mathrm{~m}[20 \mathrm{ft}]$ ), unsaturated sediments from most of the boreholes.

- PCE and TCE were detected in most soil samples, but the highest VOC concentration detected was $200 \mathrm{ppb}$ for TCE, carbon tetrachloride, and Freon 11.

- Only one groundwater sample indicated the presence of VOCs (primarily TCE, with a concentration of about $48 \mathrm{ppb}$ ).

- Tritium was not detected in any unsaturated sediment samples $(<1 \mathrm{pCi} / \mathrm{g})$; and gross alpha, gross beta, and plutonium levels in unsaturated sediment samples were not above global fallout and natural background levels.

- Tritium was detected at concentrations below $1,000 \mathrm{pCi} / \mathrm{L}$ in the groundwater.

- PCBs were detected at concentrations not exceeding $1.3 \mathrm{ppm}$ in shallow unsaturated sediments at a depth of less than $3 \mathrm{~m}(10 \mathrm{ft})$ in two of the boreholes.

- No PCBs were detected in groundwater samples.

\subsubsection{Northern Boundary Area}

Subsurface source investigations within the Northern Boundary Area (Figure 1.1) before October 1997 included 62 SVS points, 4 boreholes, and 1 monitor well. Results of these surveys and those of studies conducted pursuant to the Joint Stipulation and Order are presented in 


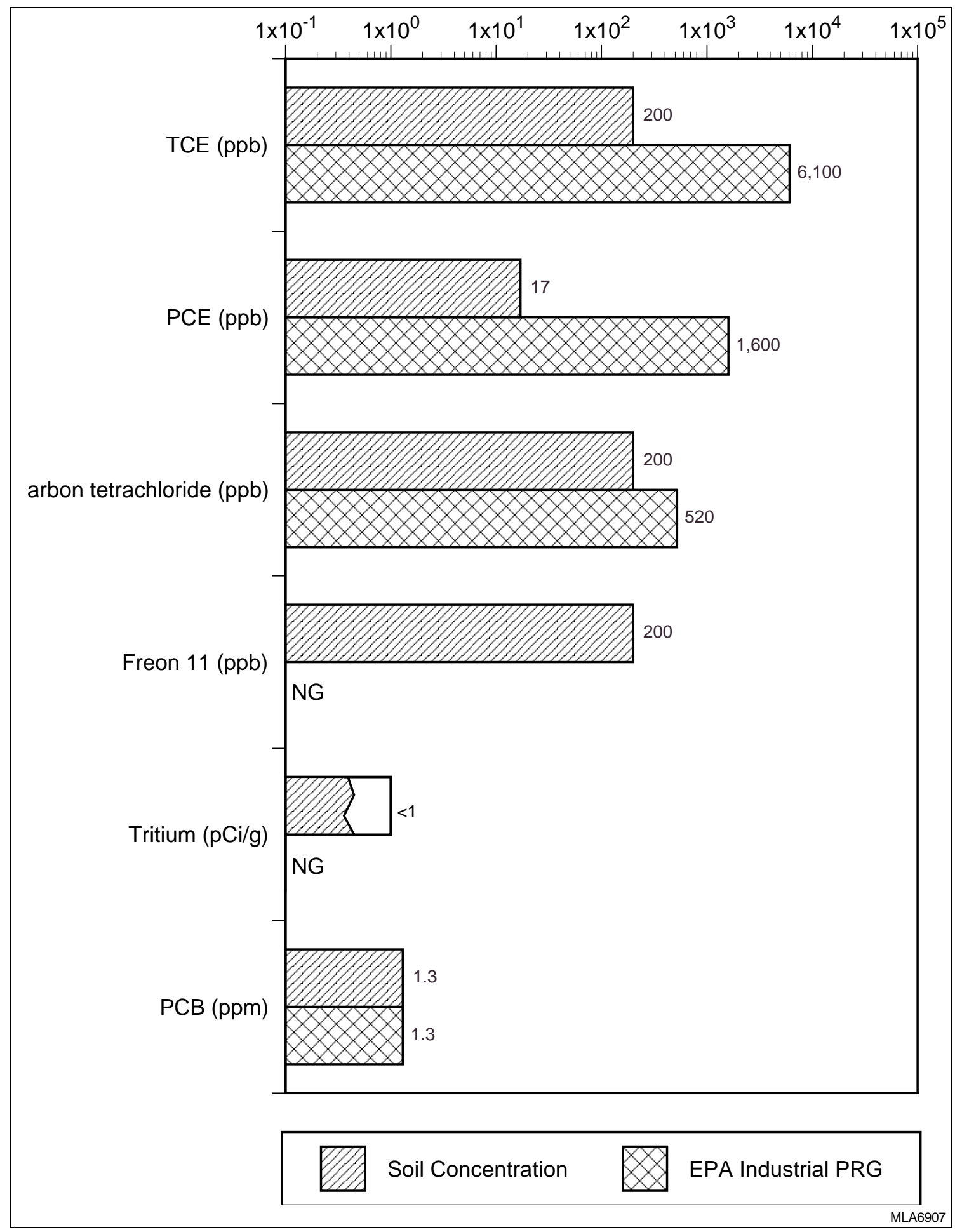

FIGURE 3.6 Soil Concentrations for the Building 571 Area and EPA Region 9 Industrial Preliminary Remediation Goals (PRGs) (NA = no data available, ND = none detected, NG = no goal) 


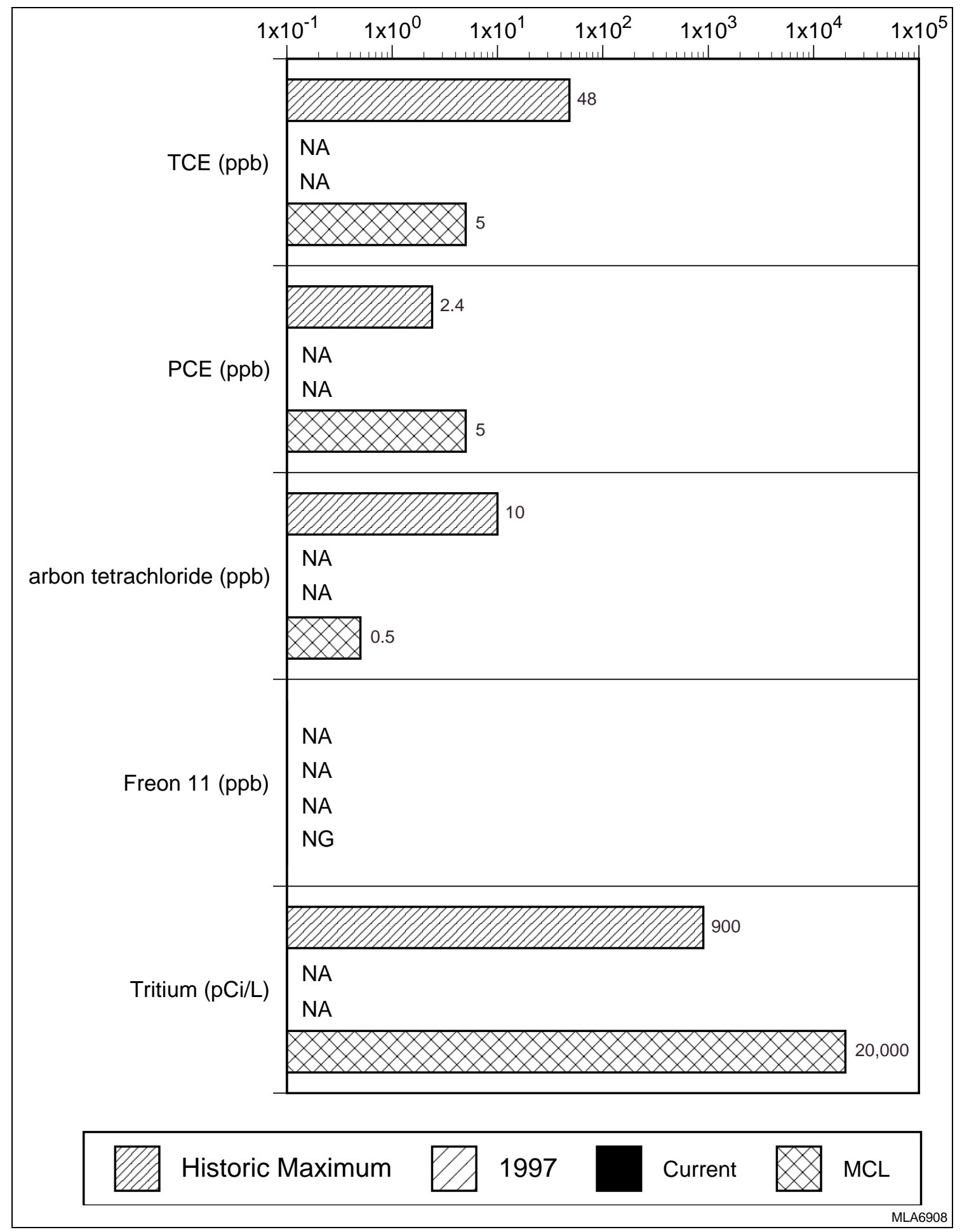

FIGURE 3.7 Groundwater Concentrations for the Building 571 Area and Maximum Concentration Limits (MCLs) for Drinking Water (NA $=$ no data available, $N D=$ none detected, $\mathbf{N G}=$ no goal) 
Tables 3.1 (soil) and 3.2 (groundwater) and are illustrated graphically in Figures 3.8 and 3.9. Major observations related to contaminants in the Northern Boundary Area are as follows:

- In general, no VOCs above 5 ppb were detected in sediment samples.

- Trace VOCs not exceeding 1 ppb were detected in a bailed groundwater sample from only one of the boreholes.

- Historically, a maximum of $250 \mathrm{ppb}$ of Freon 11 was detected in groundwater.

- Tritium was detected at a maximum concentration of $9,000 \mathrm{pCi} / \mathrm{L}$ in the water phase of one unsaturated sediment sample (borehole SIB-NBA-003). Gross alpha, gross beta, and plutonium levels in unsaturated sediment samples were not above global fallout and natural background levels.

- Tritium concentrations of $800 \mathrm{pCi} / \mathrm{L}$ were measured in groundwater samples in the vicinity of the Northern Boundary Area.

- PCBs were reported in only one unsaturated sediment sample, from a depth of $3.4 \mathrm{~m}(11 \mathrm{ft})$ at a concentration of $0.19 \mathrm{ppm}$.

\subsubsection{Building 490 Area}

Subsurface source investigations within the Building 490 Area (Figure 1.1) before October 1997 included 60 SVS points, 2 boreholes, and 6 monitor wells. Results of these surveys and those of studies conducted pursuant to the Joint Stipulation and Order are presented in Tables 3.1 (soil) and 3.2 (groundwater) and illustrated graphically in Figures 3.10 and 3.11 . Major observations related to contaminants in the Building 490 Area are as follows:

- VOCs, predominantly Freon 11, were detected at concentrations generally less than $100 \mathrm{ppb}$ in most unsaturated sediment samples collected before October 1997 from a borehole located immediately south of the building. The highest concentration of Freon 11 in saturated sediments from this borehole was $90 \mathrm{ppb}$ from SIB-490-102.

- TCE and PCE were detected in saturated sediments at concentrations less than or equal to $1 \mathrm{ppb}$. 


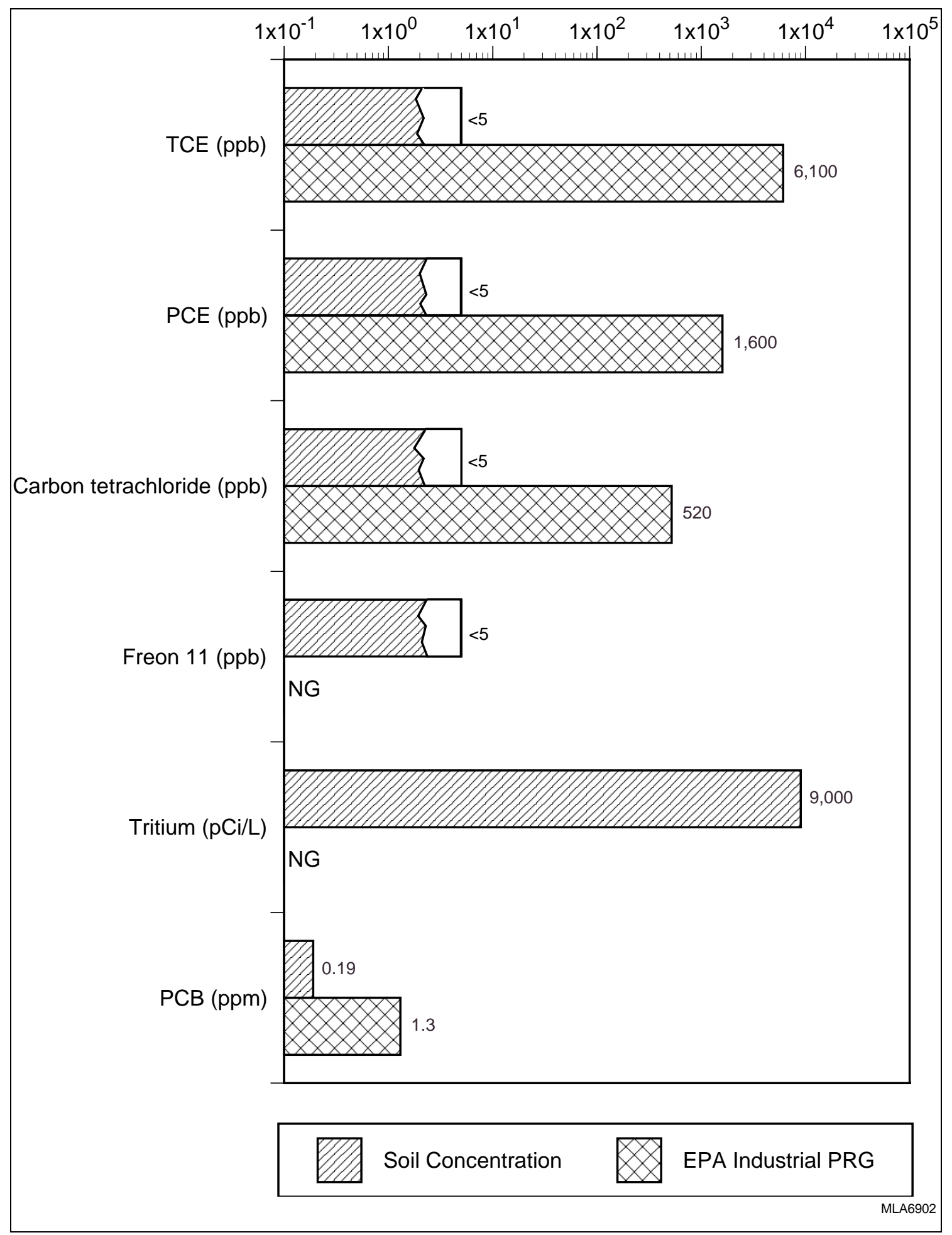

FIGURE 3.8 Soil Concentrations for the Northern Boundary Area and EPA Region 9 Industrial Preliminary Remediation Goals (PRGs) $(\mathrm{NA}=$ no data available, $\mathbf{N D}=$ none detected, $\mathbf{N G}=$ no goal) 


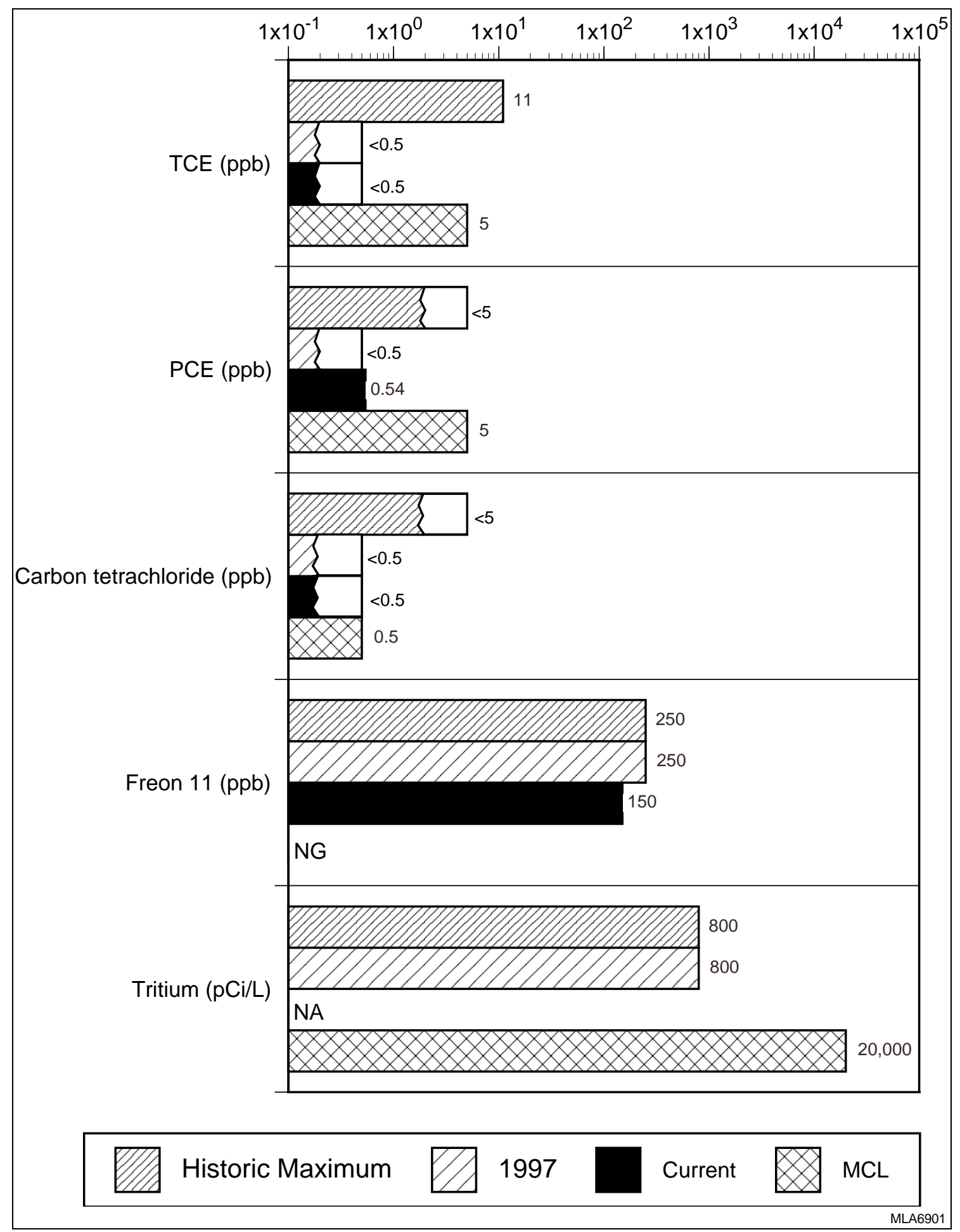

FIGURE 3.9 Groundwater Concentrations for the Northern Boundary Area and Maximum Concentration Limits (MCLs) for Drinking Water (NA = no data available, ND = none detected, $\mathrm{NG}=$ no goal) 


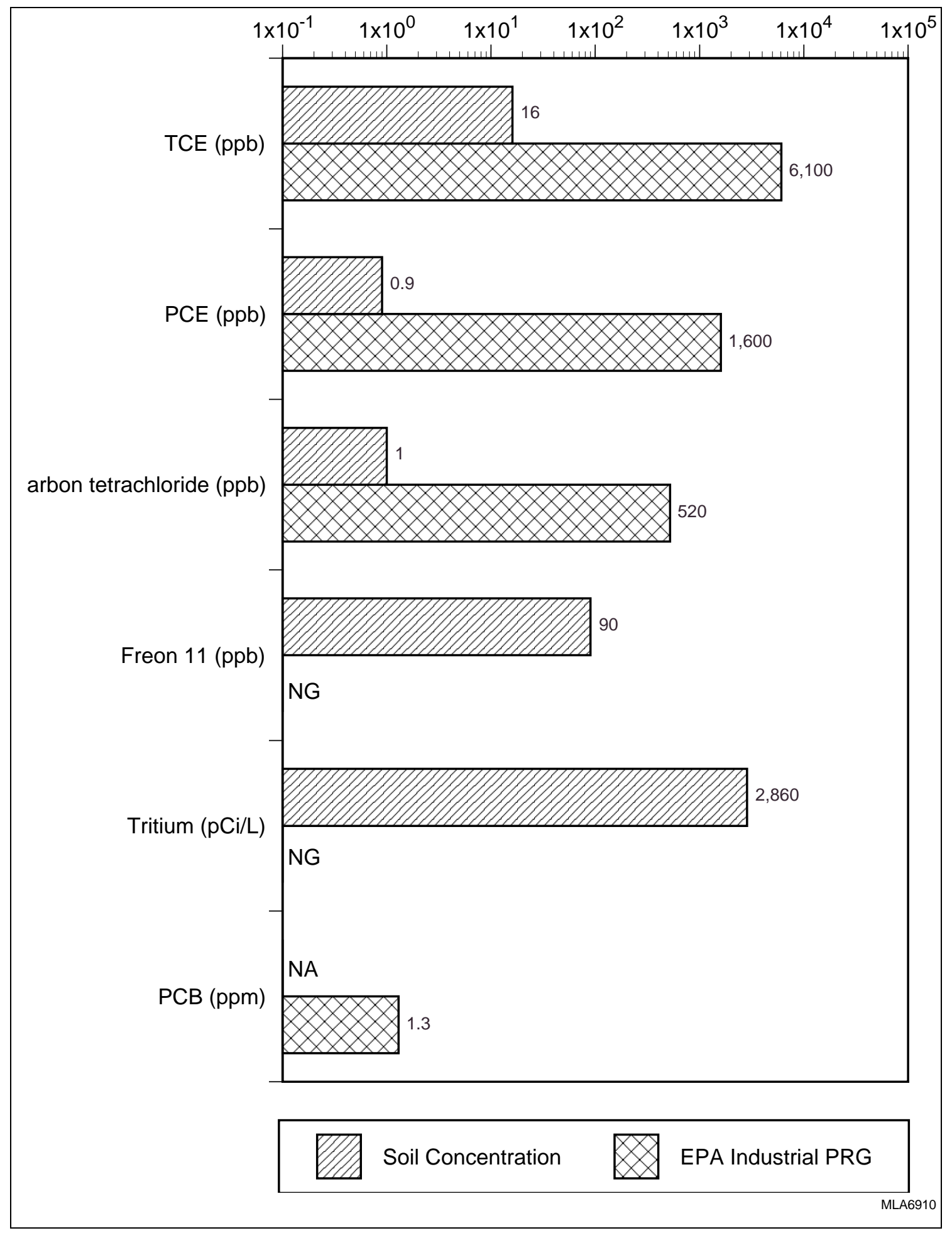

FIGURE 3.10 Soil Concentrations for the Building 490 Area and EPA Region 9 Industrial Preliminary Remediation Goals (PRGs) (NA = no data available, $\mathrm{ND}=$ none detected, $\mathbf{N G}=$ no goal) 


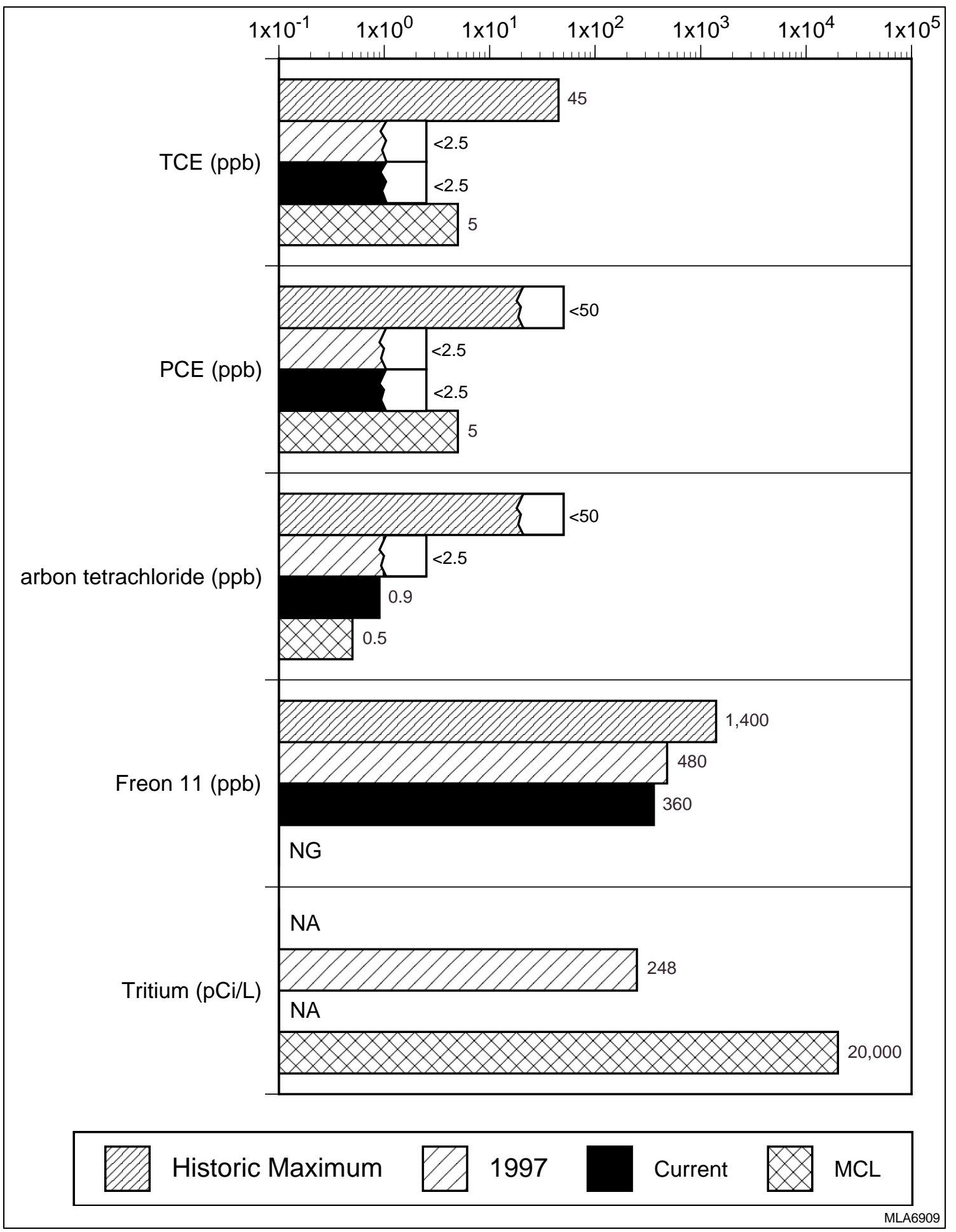

FIGURE 3.11 Groundwater Concentrations for the Building 490 Area and Maximum Concentration Limits (MCLs) for Drinking Water (NA = no data available, ND = none detected, NG = no goal) 
- VOCs (mostly TCE) were detected in groundwater samples at concentrations up to $50 \mathrm{ppb}$; by October 1997 concentrations had decreased to less than $2.5 \mathrm{ppb}$.

- Freon 11 was first detected in groundwater in August 1988. The concentration increased to a high of 1,400 ppb in August 1994. Currently, the Freon 11 concentration has decreased to $360 \mathrm{ppb}$ in this well.

- No metals were detected above their action levels in groundwater samples from wells screened in HSU 2.

- Tritium was sporadically detected at a concentration of about $2,860 \mathrm{pCi} / \mathrm{L}$ in sediment samples collected from one borehole (see Table 3.2).

- Tritium has not exceeded $1,000 \mathrm{pCi} / \mathrm{L}$ in groundwater samples from any of the monitor wells screened in HSU 2. Gross alpha and gross beta levels in HSU 2 groundwater downgradient of Building 490 were either below detection limits or within natural background levels.

\subsubsection{East Traffic Circle Area}

The ETC Area (Figure 1.1) contained a former landfill that was excavated in 1984. Before October 1997, source investigations were initiated after the landfill was excavated and included 119 SVS points, 30 boreholes, and 15 monitor wells. Results of these surveys, surveys conducted pursuant to the Joint Stipulation and Order, and surveys performed during PCB cleanup activities in 1998-1999 are presented in Tables 3.1 (soil) and 3.2 (groundwater) and illustrated graphically in Figures 3.12 and 3.13. Major observations related to contaminants in the ETC Area are as follows:

- VOCs (TCE and PCE) were detected in recent surveys in most of the unsaturated sediment samples at total VOC concentrations generally less than $1,000 \mathrm{ppb}$. Historic maximums are 1,600 ppb.

- Total VOC concentrations in groundwater from wells screened in HSU 2 were as high as 3,600 ppb in May 1987.

- Current VOC groundwater concentrations in HSU 2 are generally below $1,000 \mathrm{ppb}$, and in some locations have decreased to less than $100 \mathrm{ppb}$ because of active pump-and-treat. 


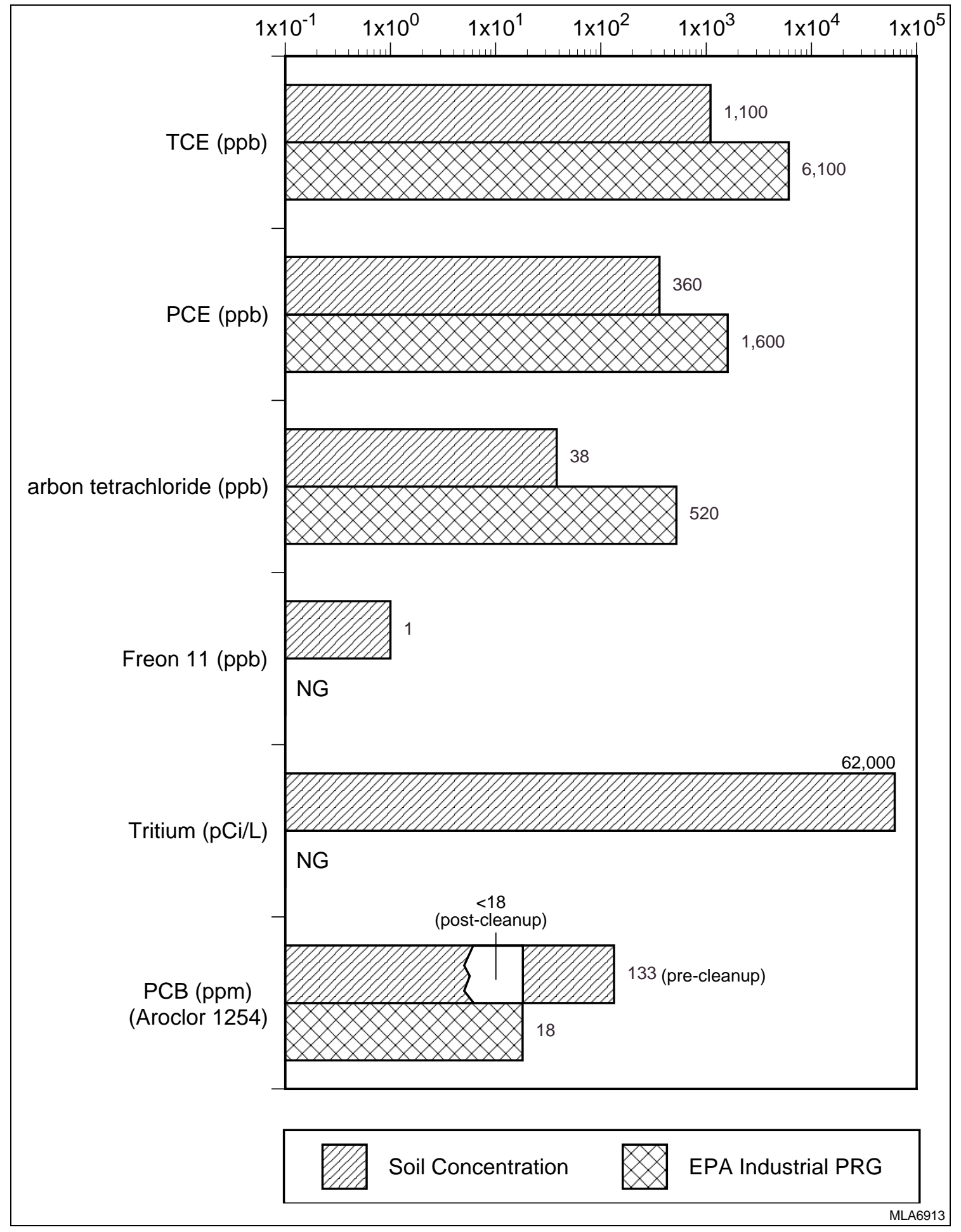

FIGURE 3.12 Soil Concentrations for the East Traffic Circle Area and EPA Region 9 Industrial Preliminary Remediation Goals (PRGs) (NA = no data available, $\mathbf{N D}=$ none detected, NG = no goal) 


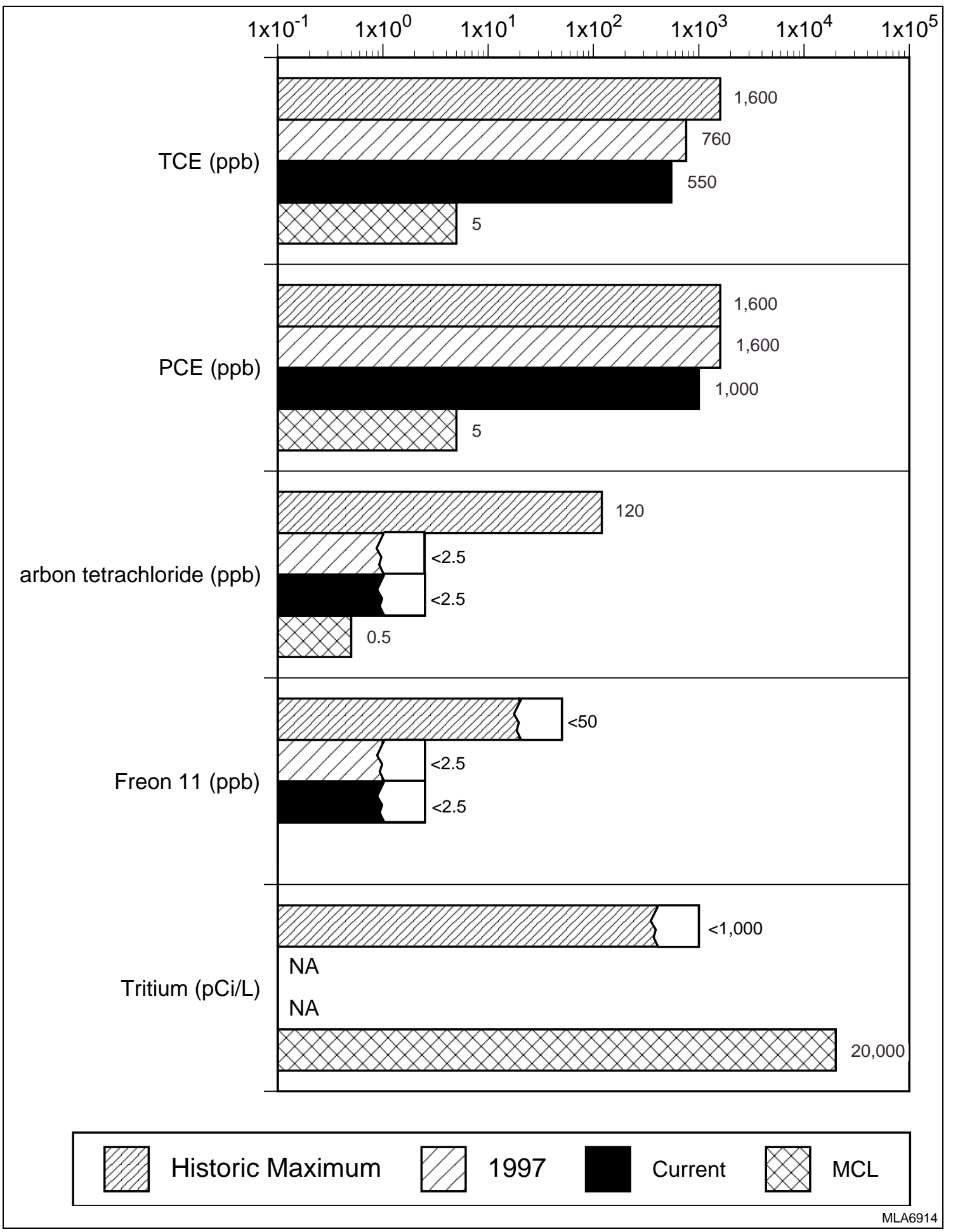

FIGURE 3.13 Groundwater Concentrations for the East Traffic Circle Area and Maximum Concentration Limits (MCLs) for Drinking Water (NA = no data available, $\mathrm{ND}=$ none detected, $\mathrm{NG}=$ no goal) 
- The maximum TCE concentration in sediment was $1,100 \mathrm{ppb}$; PCE had a maximum concentration of $360 \mathrm{ppb}$ in SIB-ETC-001 (see Table 3.1).

- Tritium was detected in a few unsaturated sediment samples at concentrations up to $62,000 \mathrm{pCi} / \mathrm{L}$.

- One PCB (Aroclor 1254) was detected in an unsaturated sediment sample from a depth of $0 \mathrm{~m}$ at a concentration of $133 \mathrm{ppm}$; recent cleanup activities have reduced PCB levels to less than 18 ppm (Picel 1999).

- PCBs have not been detected in groundwater samples, including samples from new monitor well W-1403.

\subsubsection{East Gate Drive Area}

No hazardous materials are known to have been used, stored, handled, or disposed of in the East Gate Drive Area (Figure 1.1). However, an elevated concentration of PCE was detected in a sediment sample collected from a depth of $1.5 \mathrm{~m}(5 \mathrm{ft})$ in a borehole drilled as part of the preconstruction sampling for the Western Area Power Association powerline project. Because of this discovery, additional subsurface source investigations were performed. Those investigations included 54 SVS points, 16 boreholes, and 1 monitor well before October 1997. Results of these surveys and those of studies conducted pursuant to the Joint Stipulation and Order are presented in Tables 3.1 (soil) and 3.2 (groundwater) and illustrated graphically in Figures 3.14 and 3.15. Major observations related to contaminants in the East Gate Drive Area are:

- VOCs, at a concentrations up to $1.3 \mathrm{ppb}$ have been detected in groundwater. No current individual VOC concentration is above its MCL.

- The maximum TCE concentration (1.3 ppb) was found in well W-221; this value decreased to $<0.5 \mathrm{ppb}$ in December 1996 (Table 3.1).

- PCE was detected in unsaturated sediments, mostly within the upper $3 \mathrm{~m}$ $(10 \mathrm{ft})$ and generally at concentrations less than $500 \mathrm{ppb}$. The highest concentration detected was $9,800 \mathrm{ppb}$ PCE in a sample collected at the $1.5-\mathrm{m}$ (5-ft) level from a preconstruction borehole.

- Tritium was detected at up to $2,100 \mathrm{pCi} / \mathrm{L}$ in unsaturated sediment samples and was not detected above $1,000 \mathrm{pCi} / \mathrm{L}$ in groundwater.

- No PCBs were detected in unsaturated sediment samples or in groundwater from downgradient wells completed in HSU 2. 


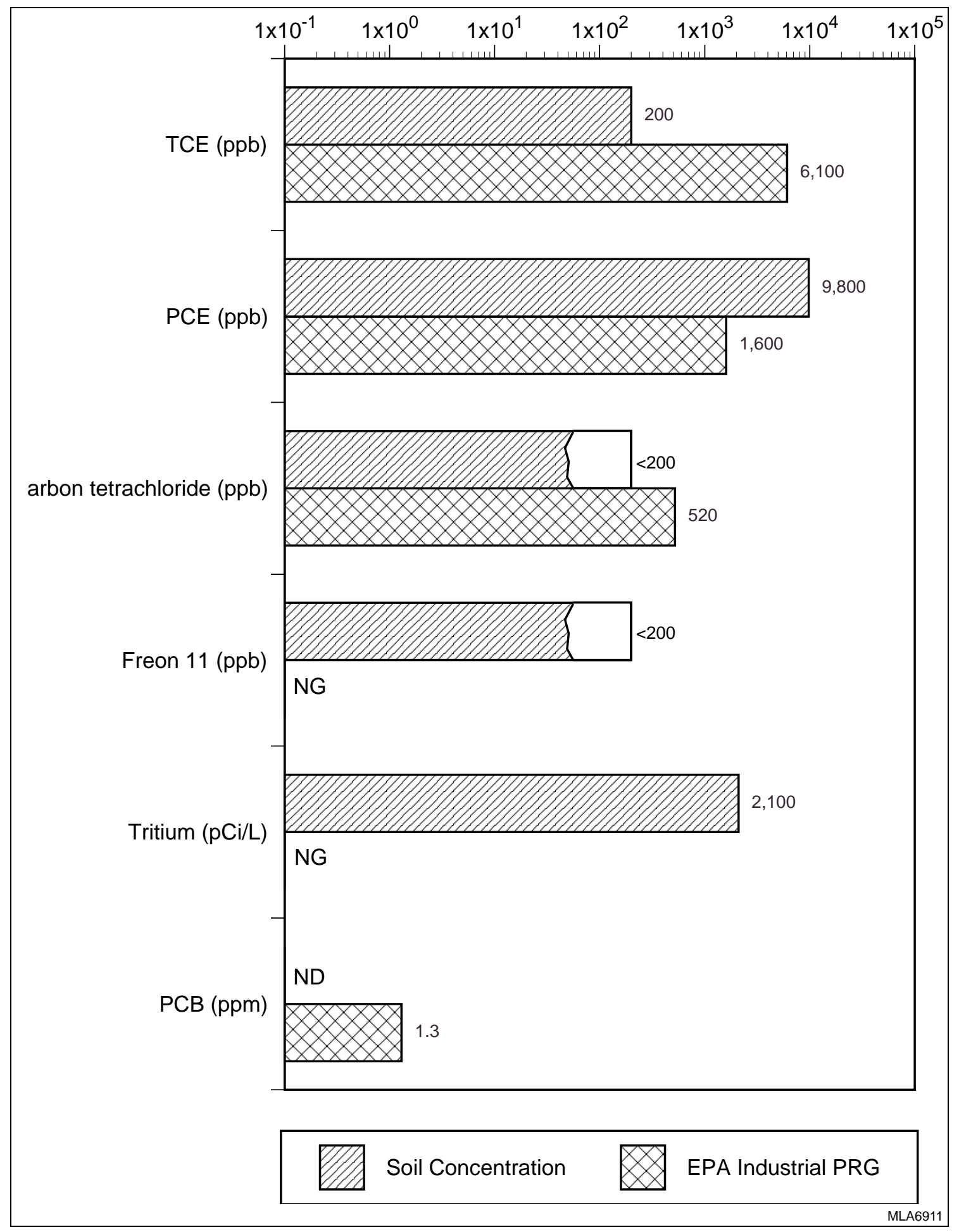

FIGURE 3.14 Soil Concentrations for the East Gate Drive Area and EPA Region 9 Industrial Preliminary Remediation Goals (PRGs) (NA = no data available, ND = none detected, $\mathrm{NG}=$ no goal) 


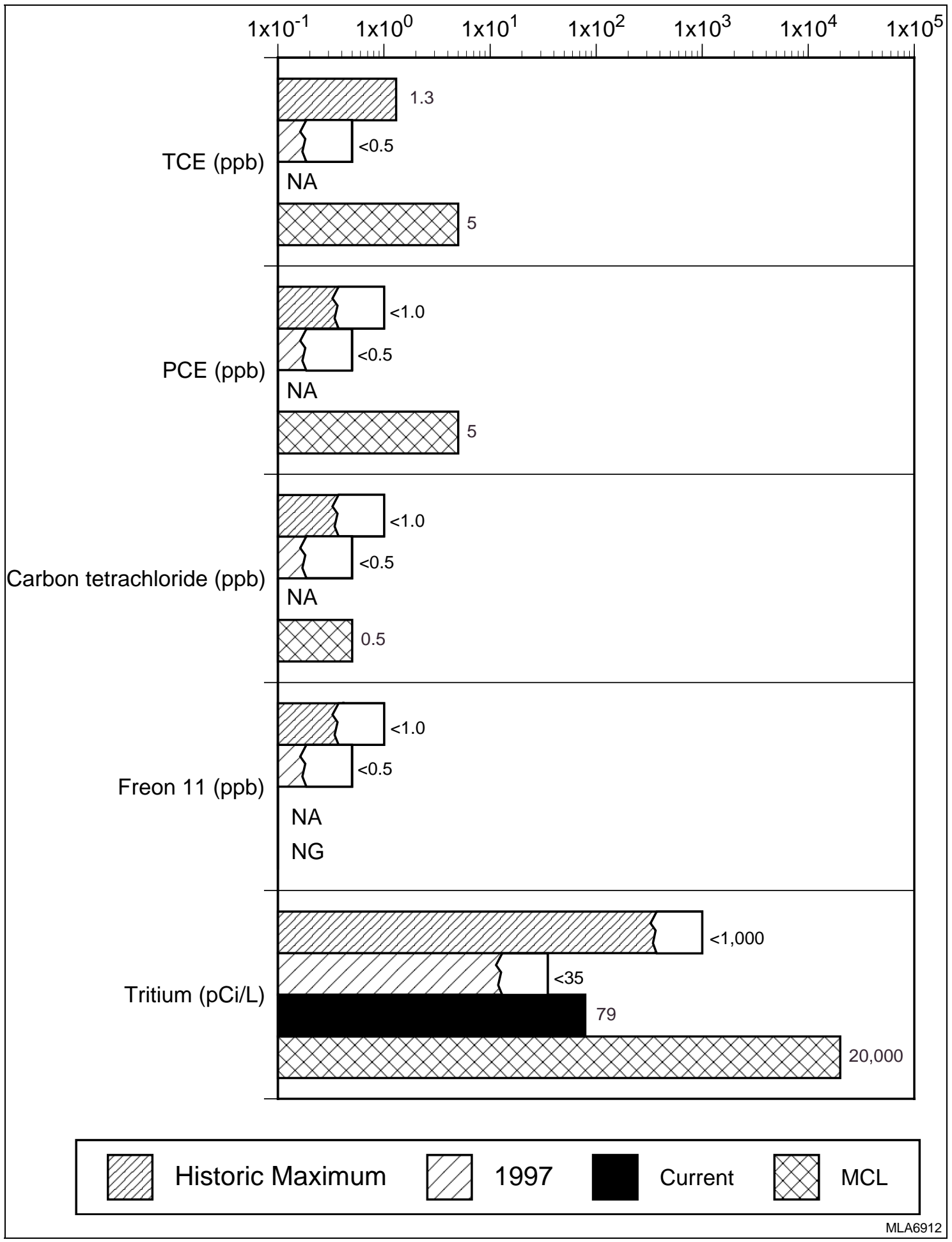

FIGURE 3.15 Groundwater Concentrations for the East Gate Drive Area and Maximum Concentration Limits (MCLs) for Drinking Water (NA = no data available, $\mathbf{N D}=$ none detected, $\mathbf{N G}=$ no goal) 


\subsubsection{NIF Construction Area}

No historical data were found indicating that hazardous materials had been used, stored, handled, or disposed of in the NIF Construction Area. Subsurface investigations before October 1997 included samples from one HSU 2 monitor well in the area and two downgradient HSU 2 monitor wells within $76 \mathrm{~m}(250 \mathrm{ft})$ of the area. Results of these surveys and those of studies conducted pursuant to the Joint Stipulation and Order are presented in Tables 3.1 (soil) and 3.2 (groundwater) and illustrated graphically in Figures 3.16 and 3.17. Major observations related to contaminants in the NIF Construction Area are as follows:

- No groundwater from wells in the NIF area currently contains contaminants above the MCLs. The NIF site is outside the area where VOCs in groundwater were above MCLs in 1998.

- TCE and PCE concentrations of up to $200 \mathrm{ppb}$ were detected in unsaturated sediment samples collected in the NIF area.

- Groundwater samples collected from the one HSU 2 well in the area have historically contained total VOCs at concentrations mostly less than $10 \mathrm{ppb}$. The maximum TCE concentration measured was 16 ppb. In April 1997, this value decreased to $<0.5 \mathrm{ppb}$.

- Tritium levels in unsaturated sediments were reported to be less than $5,200 \mathrm{pCi} / \mathrm{L}$.

- Tritium concentration in the groundwater is less than $1,000 \mathrm{pCi} / \mathrm{L}$.

- PCBs have not been detected (detection limit of $0.0005 \mathrm{ppm}$ ) in any of the wells in the vicinity of the excavated capacitors and contaminated soil.

- The maximum PCB concentration in soil was $66 \mathrm{ppm}$ before cleanup. Concentrations are now less than 1 ppm (Picel 1999).

\subsection{ONGOING REMEDIATION ACTIVITIES AT THE SITE}

A number of extraction wells and groundwater treatment facilities have been constructed to reduce contamination at LLNL (Berg et al. 1997). These facilities are shown in Figure 3.18. In 1997, there were three extraction wells and one fixed (TFD) and two portable groundwater treatment units (TFD East and TFD West) in the vicinity of the Helipad Area. Portable groundwater treatment unit TFD Southeast started operation in March 1998. 


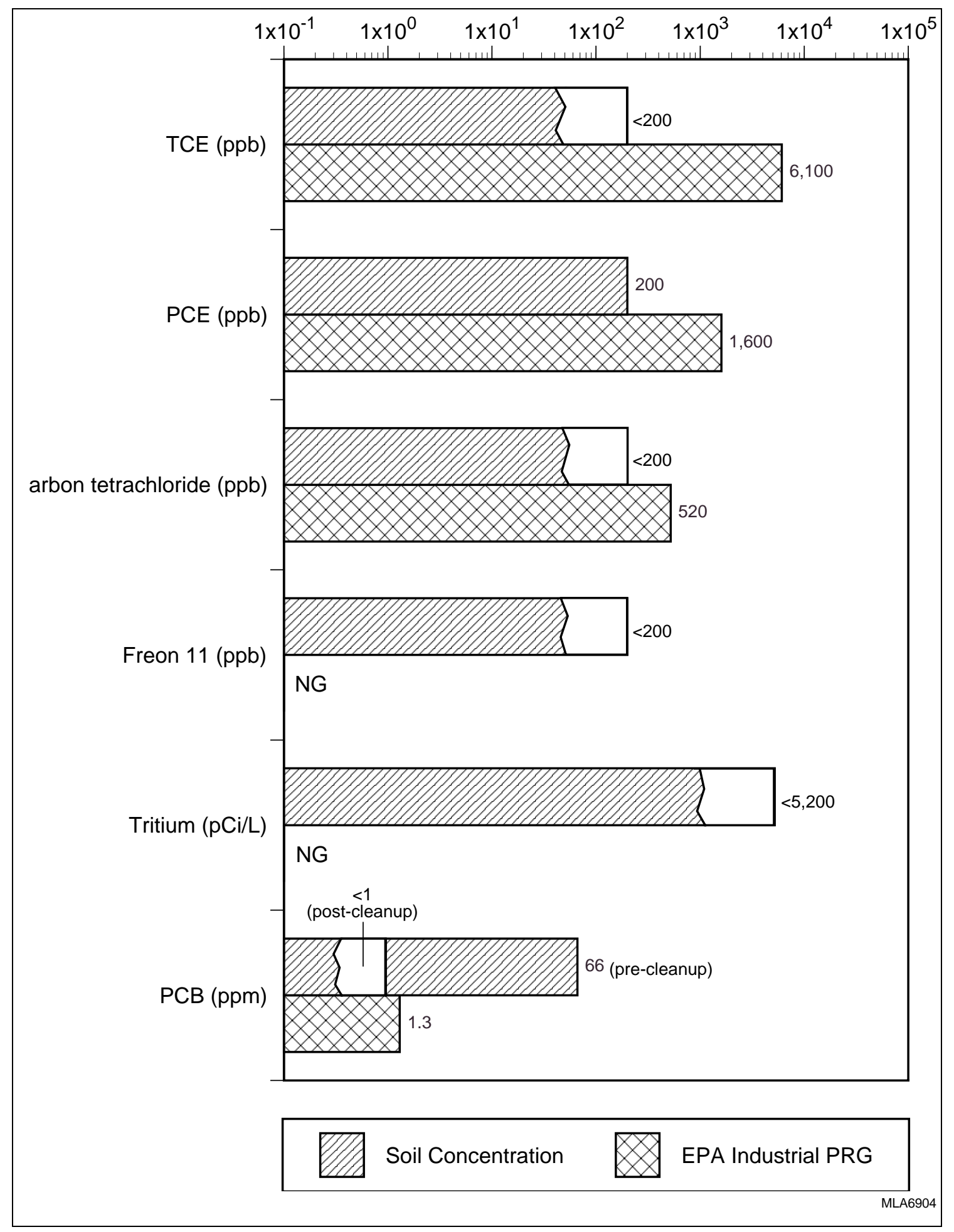

FIGURE 3.16 Soil Concentrations for the NIF Construction Area and EPA Region 9 Industrial Preliminary Remediation Goals (PRGs) (NA = no data available, $\mathbf{N D}=$ none detected, $\mathbf{N G}=$ no goal) 


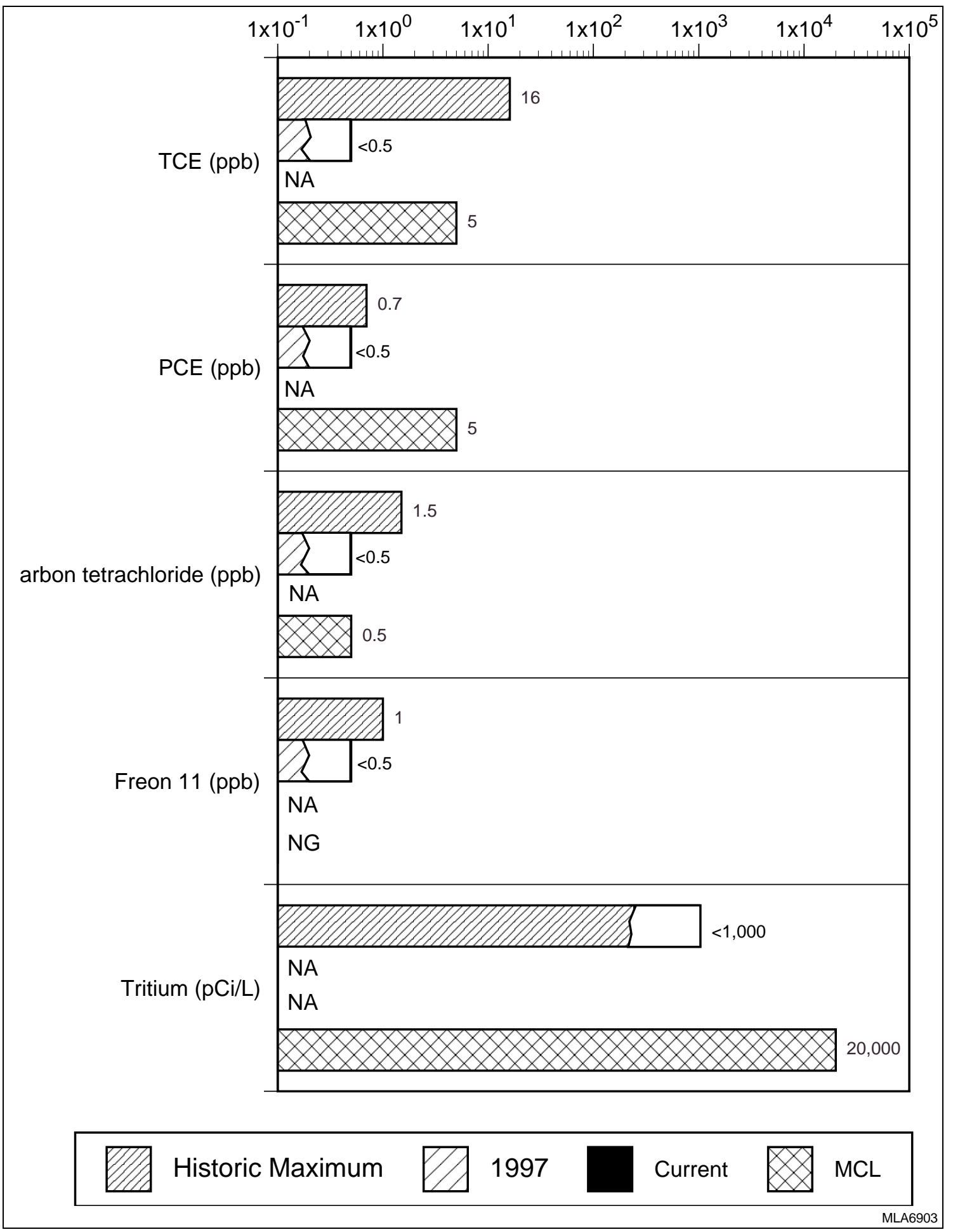

FIGURE 3.17 Groundwater Concentrations for the NIF Construction Area and Maximum Concentration Limits (MCLs) for Drinking Water (NA = no data available, $\mathrm{ND}=$ none detected, $\mathrm{NG}=$ no goal) 


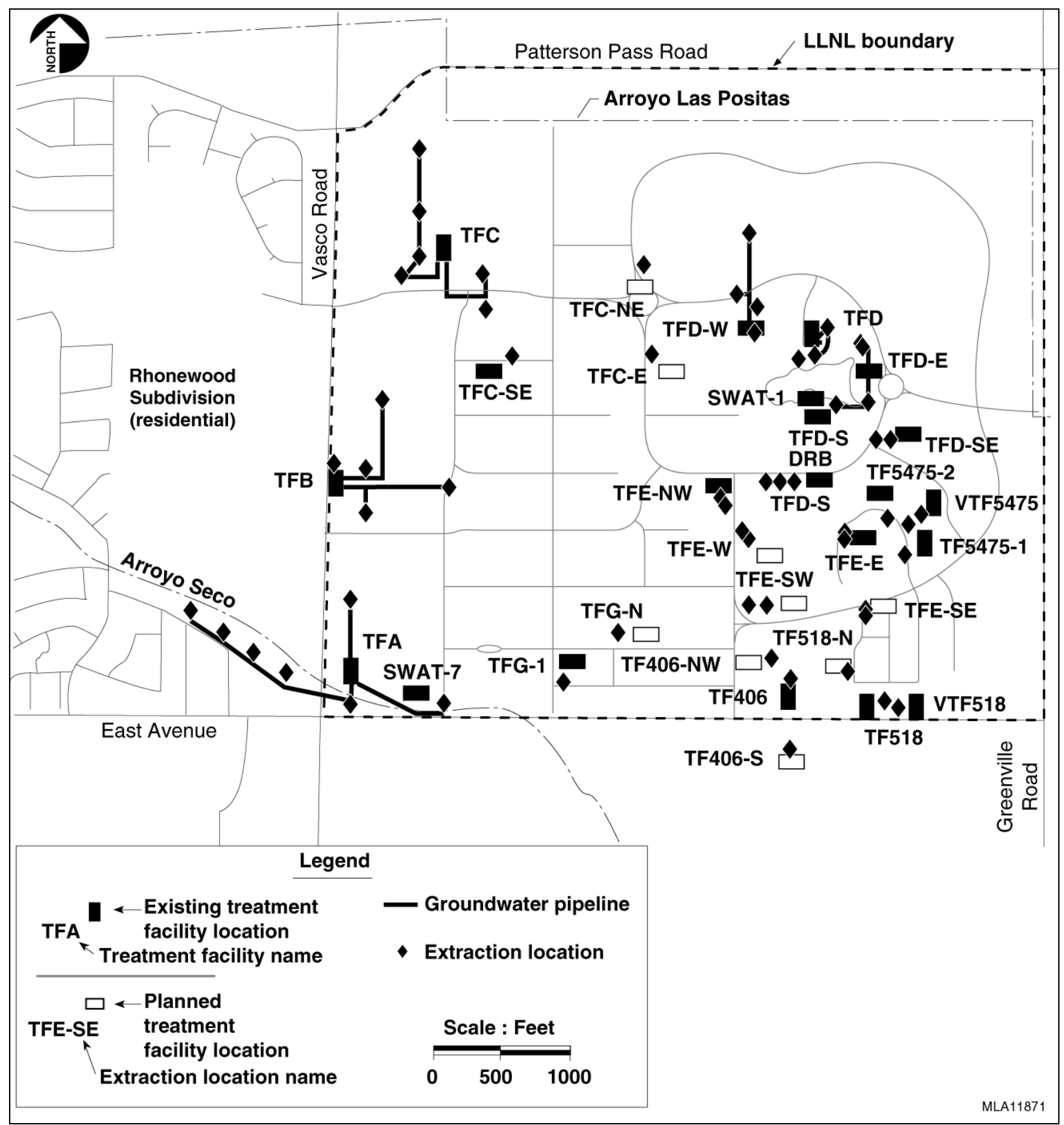

FIGURE 3.18 Planned and Existing Groundwater and Soil Vapor Extraction Locations at the LLNL Site 
Pumping at the extraction wells has modified the groundwater elevations. Elevations for HSUs 1 through 5 are shown in Figures 3.19 through 3.24. The shallowest unit (HSU 1) is unsaturated in the vicinity of the NIF site (Figure 3.19). Groundwater flow in the vicinity of HSUs 2 and 3 (Figures 3.20 to 3.22) is to the west-southwest. HSU 2 well W-273 (Figure 3.25) is the first well downgradient from the NIF excavation. Groundwater samples collected from this well contain no volatile organic compounds or PCBs. The effects of the extraction well are much more obvious in HSU 4. Extraction of groundwater from this unit has produced a 4.6-m (15-ft) deep drawdown cone of depression centered on the extraction wells; flow in this unit is radially convergent on the extraction wells (Figure 3.23). The extraction wells have had little influence on HSU 5, as seen in Figure 3.24. Flow in the vicinity of the NIF in this groundwater unit is to the west-northwest. As indicated in Table 3.2, there has been a substantial decrease in groundwater contamination for some substances compared with historic maximums because of the active remediation activities being conducted at the site. 


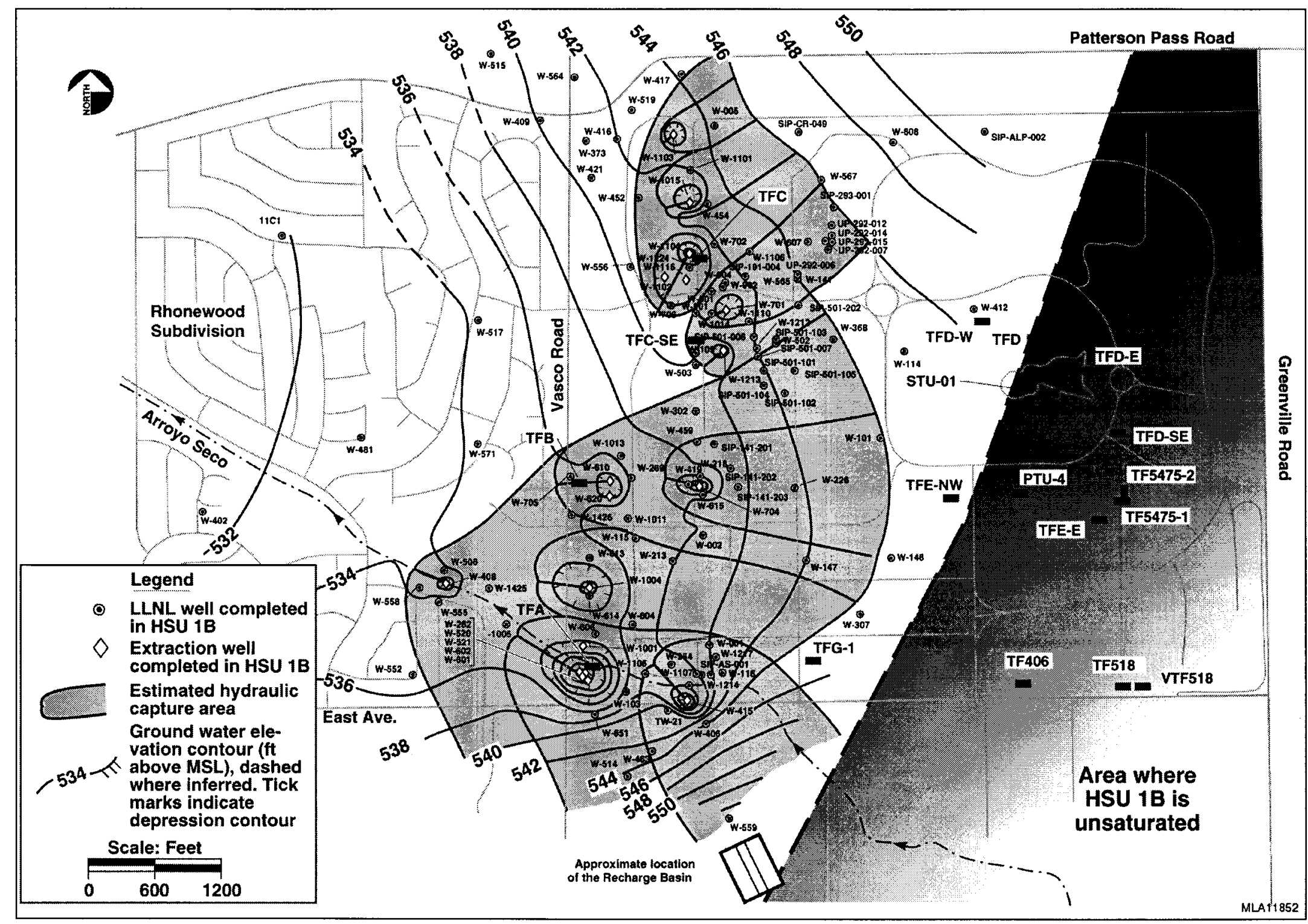

FIGURE 3.19 Groundwater Elevation Contour Map Based on Water Levels Collected from 130 Wells Completed within HSU 1B Showing Estimated Hydraulic Capture Areas, LLNL and Vicinity, February 1999 


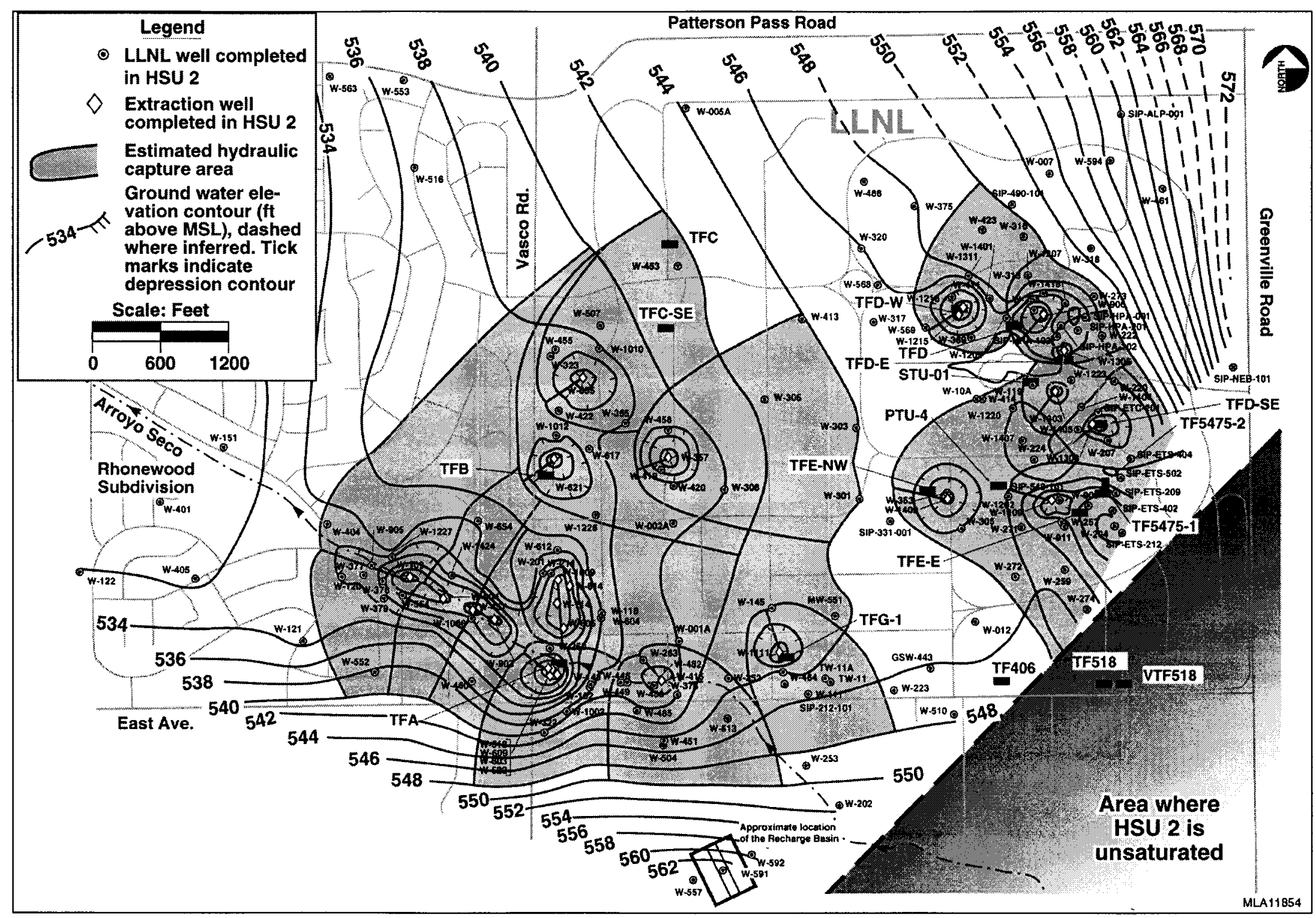

FIGURE 3.20 Groundwater Elevation Contour Map Based on Water Levels Collected from 167 Wells Completed within HSU 2 Showing Estimated Hydraulic Capture Areas, LLNL and Vicinity, February 1999 


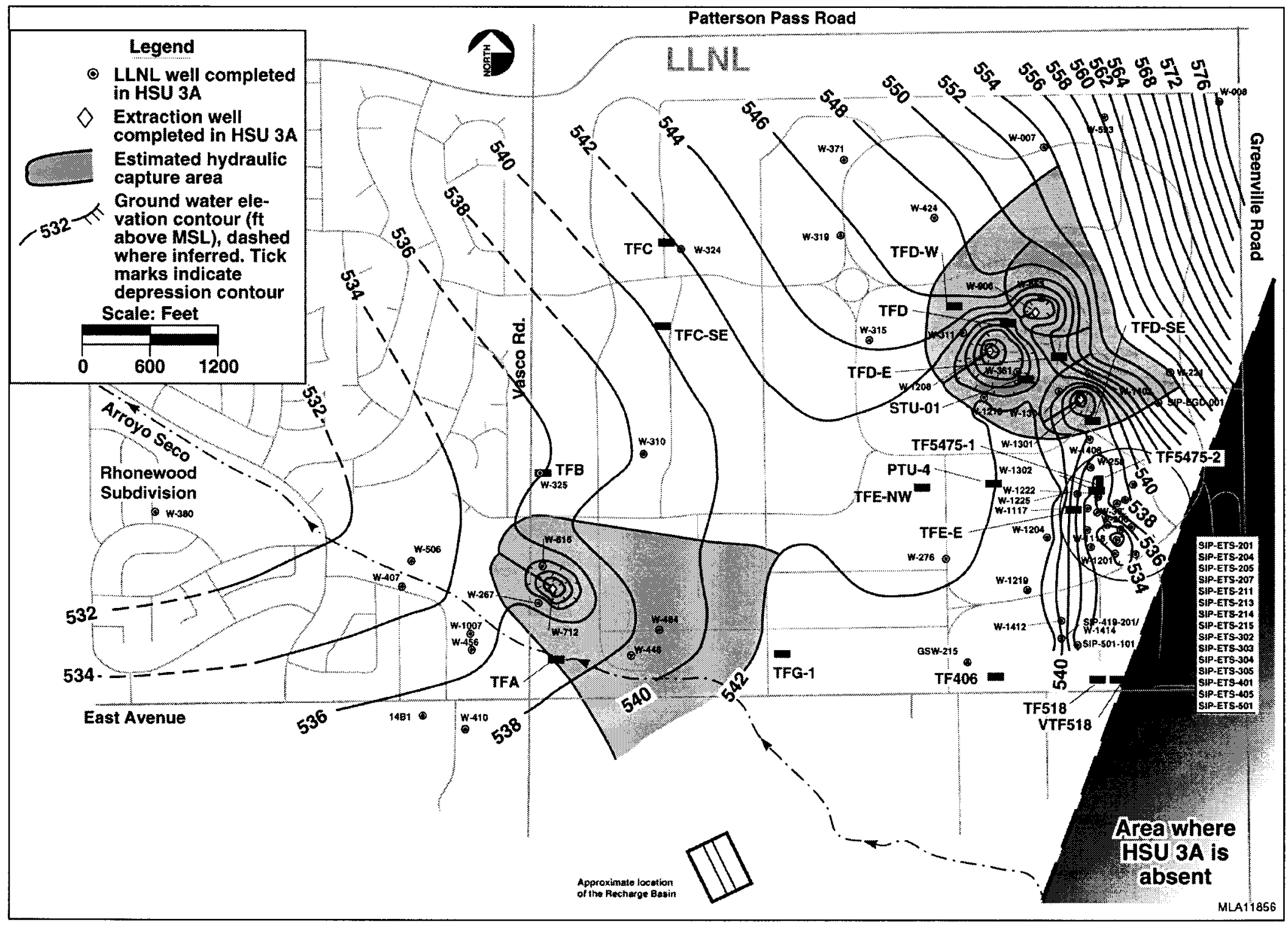

FIGURE 3.21 Groundwater Elevation Contour Map Based on Water Levels Collected from 63 Wells Completed within HSU 3A Showing Estimated Hydraulic Capture Areas, LLNL and Vicinity, February 1999 


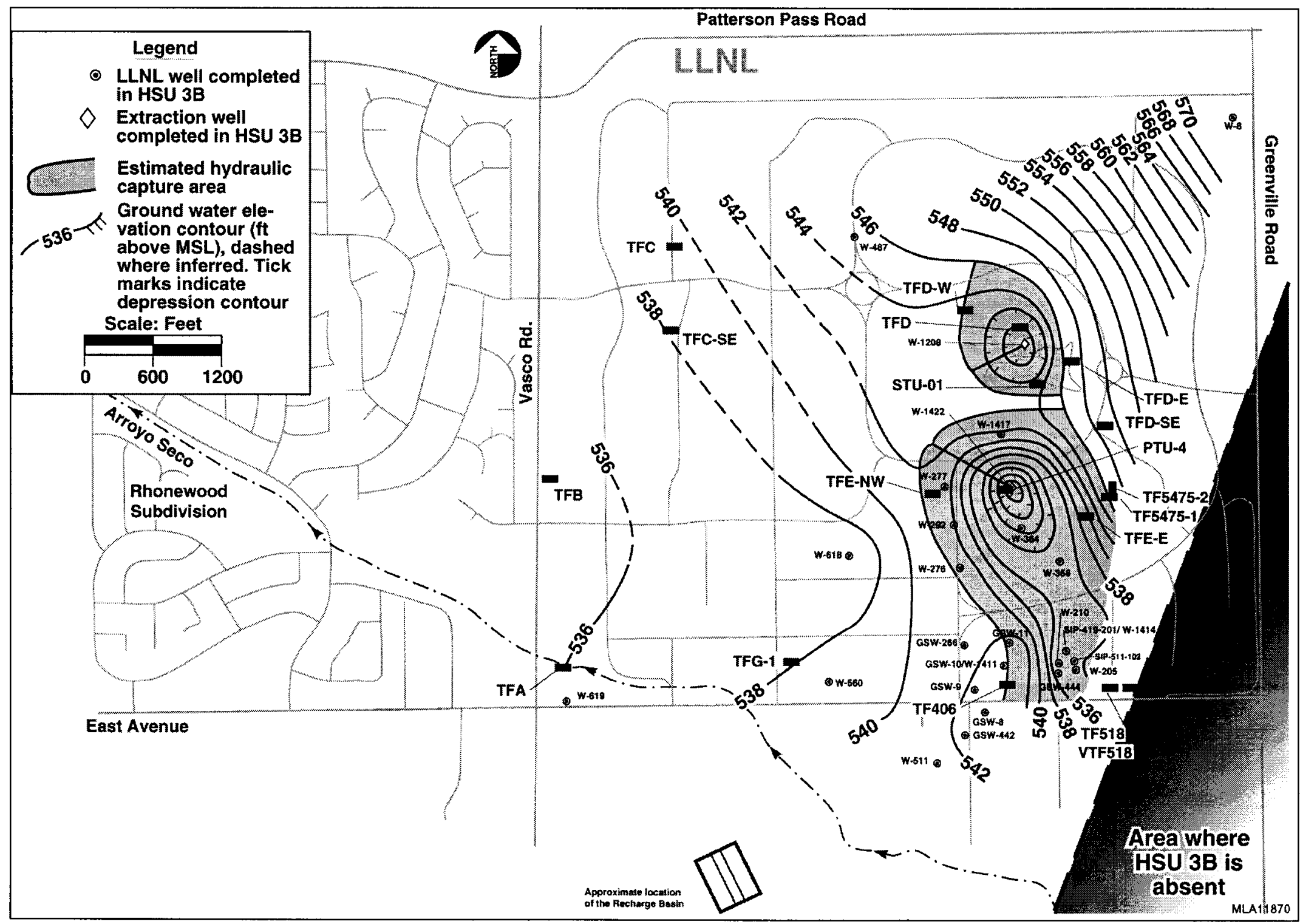

FIGURE 3.22 Groundwater Elevation Contour Map Based on Water Levels Collected from 25 Wells Completed within HSU 3B Showing Estimated Hydraulic Capture Areas, LLNL and Vicinity, February 1999 


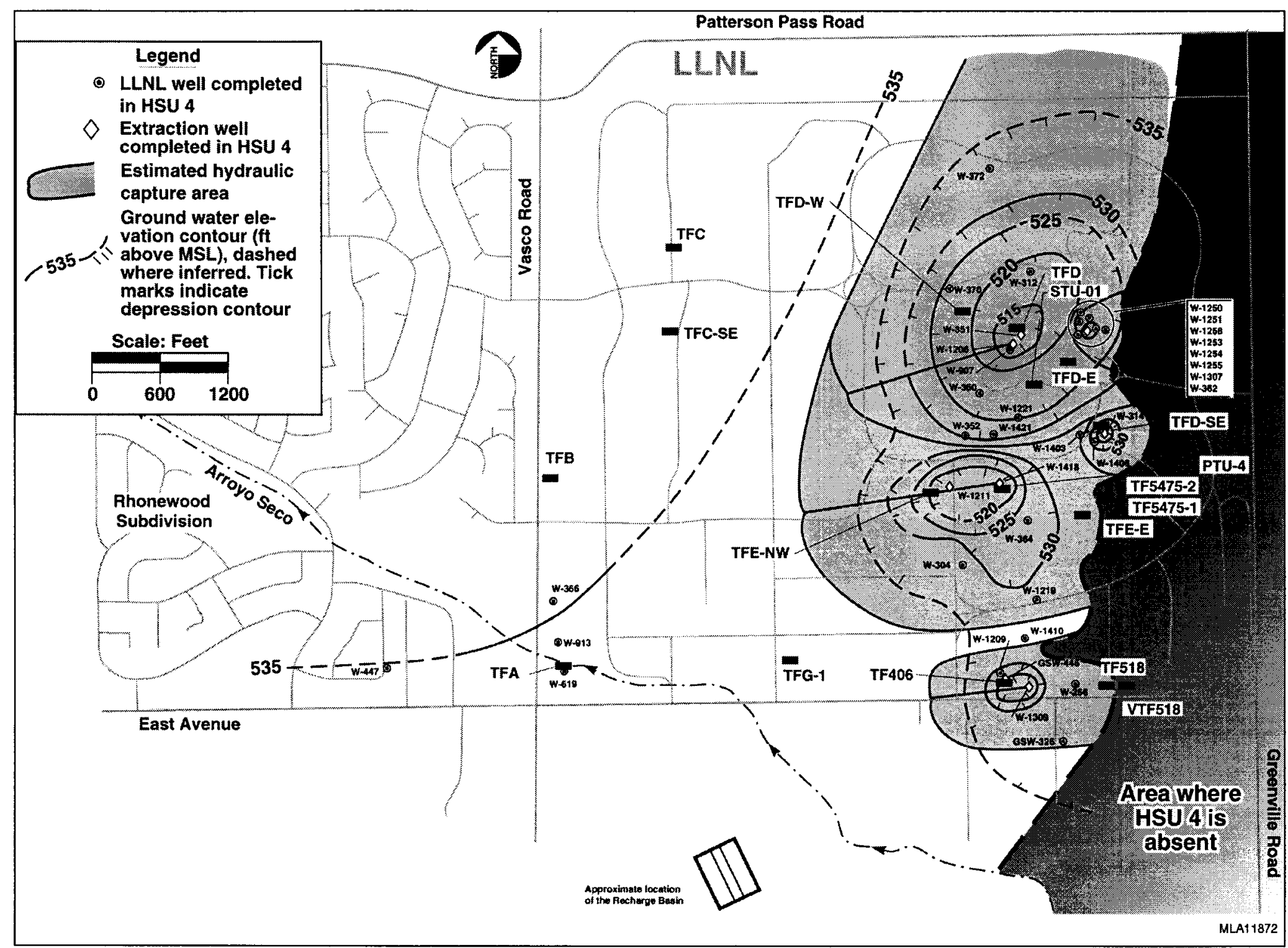

FIGURE 3.23 Groundwater Elevation Contour Map Based on Water Levels Collected from 35 Wells Completed within HSU 4 Showing Estimated Hydraulic Capture Areas, LLNL and Vicinity, February 1999 


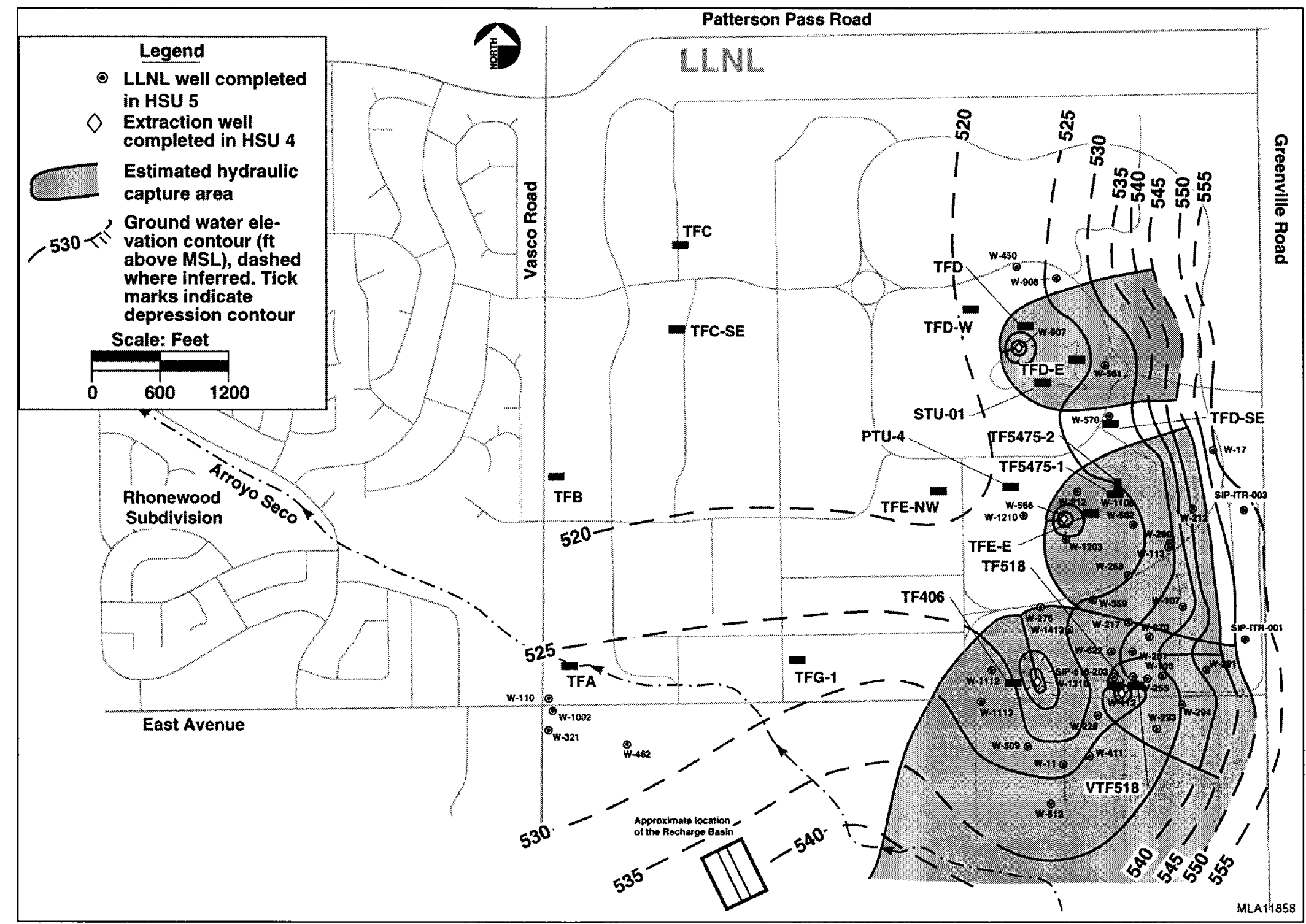

FIGURE 3.24 Groundwater Elevation Contour Map Based on Water Levels Collected from 46 Wells Completed within HSU 5 Showing Estimated Hydraulic Capture Areas, LLNL and Vicinity, February 1999 


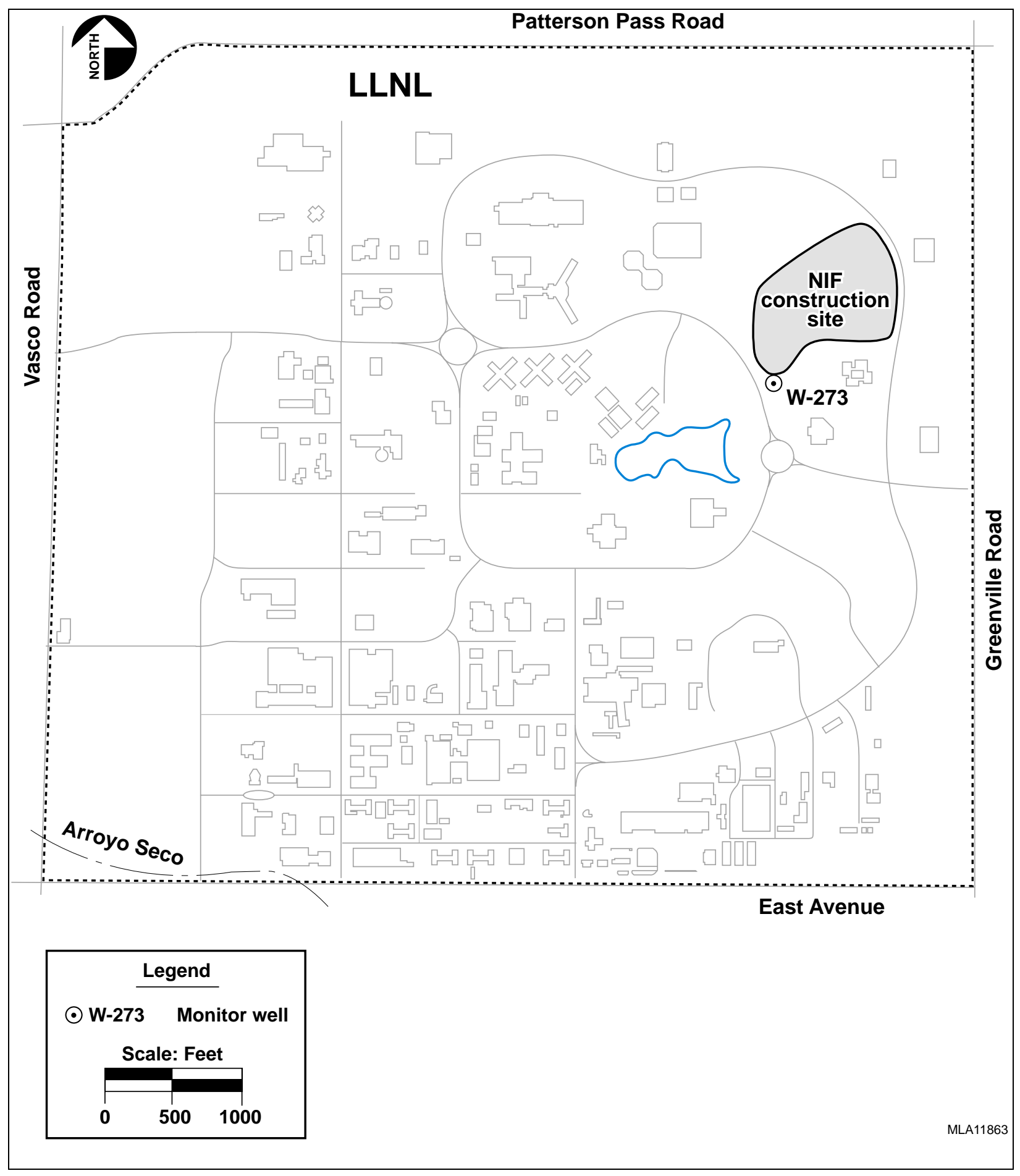

FIGURE 3.25 Location of Monitor Well W-273 Downgradient of the NIF Construction Site 


\section{ENVIRONMENTAL IMPACTS}

This section summarizes the results of the Phase I and Phase II characterization activities required by the Joint Stipulation and Order (see Section 1.3) and evaluates potential impacts to LLNL workers and to the public from construction and operation of the NIF because of the possible presence of buried hazardous, toxic, or radioactive materials in the northeastern quadrant of the LLNL site as stipulated in Paragraph 2 of the Joint Stipulation and Order. The possible contamination of soil and water by buried wastes is described, and potential human exposures and health impacts are evaluated.

The results of the Phase I and II investigations, as well as data collected to support the closure of the capacitor landfill discovered at the NIF site in 1997 and the removal of residual contamination at the ETC in 1998-1999, form the basis of evaluations of potential impacts from the excavation and closure of the capacitor landfill in the NIF Construction Area and excavation and cleanup of the ETC Area. Such possible impacts include exposure to PCB-contaminated dusts generated during excavation of newly discovered but formerly contaminated soils and the excavation of residual soil contamination from previous cleanup actions. Groundwater impacts from residual PCBs in soil were also assessed.

\subsection{PHASE I AND PHASE II CHARACTERIZATION ACTIVITIES}

The Phase I and Phase II activities were conducted pursuant to the Joint Stipulation and Order for the purposes of establishing the presence or absence of any additional buried, hazardous, toxic, or radioactive materials, and they form the basis for impacts assessment. Phase I was a review of records, aerial photographs, and interviews; Phase II was the field program. Levels of contaminants found in Phase I and Phase II investigations were included in the description of the affected environment in Section 3. Section 4.1 evaluates whether there are any additional suspected sources in the stipulated areas that should be assessed.

\subsubsection{Summary of Phase I Results}

To locate any additional hazardous, toxic, or radioactive wastes buried in the stipulated areas, a series of increasingly detailed reviews and investigations were conducted (DOE 1997, 1998a-c). Phase I activities consisted of (1) review of existing documents and other available records, (2) review of aerial photographs (from 1949-1985), and (3) interviews with long-time employees and retirees (DOE 1997, 1998a-c). The documents reviewed included the historical record of waste management and sampling and characterization activities in the stipulated areas. These sampling and characterization documents date from 1982 to 1996 and include documents prepared for state and federal agencies to satisfy environmental regulations. The first comprehensive environmental document assembled is known as the Dreicer Report (Dreicer 
1985), which reviewed uses, storage, and disposal of hazardous materials at LLNL up until 1985. While the Dreicer Report was primarily a review of historical information and a survey of waste management practices, many other reports covered specific sampling and characterization activities, including key monthly reports from the Environmental Restoration Division. The reviewed reports are listed in Attachment 2 of the February 1998 quarterly report on stipulated activities (DOE 1998a).

The reviewed documents indicate that, prior to 1964, storage and disposal of potentially hazardous materials was limited to the East Traffic Circle Landfill (ETCL) and an area that is now the current NIF construction site and where buried PCB capacitors were unearthed in 1997. A review of aerial photographs suggests the latter landfill was closed by 1965 and has since been remediated. The ETCL continued to operate until about 1974. It was excavated and closed in the mid-1980s (McConachie et al. 1986). As discussed in Section 1.1, soil containing residual PCBs was excavated from the East Traffic Circle during routine drainage maintenance operations in 1998 and was disposed of at an EPA-approved facility for CERCLA waste (Clive, Utah, incinerator).

There is no record of any recent disposal of any hazardous materials on the Livermore Site. Reports indicate that nonhazardous materials, including construction debris and soil, were managed in the northeastern quadrant of the Livermore Site (Northern Boundary Area and along the eastern boundary). Materials were stored in piles and later used as fill material to raise the grade of the area.

Reviewed documents indicate that soil characterization studies conducted in 1983 in the Building 571 Area before that building was constructed involved surface soil sampling of a $210-\times 270-\mathrm{m}(700-\times 900-\mathrm{ft})$ area on a $60-\mathrm{m}(200-\mathrm{ft})$ grid. The drilling of 20 borings as deep as $15 \mathrm{~m}$ (50 ft) was summarized in a 1983 LLNL internal memo (Dreicer 1983). Samples were analyzed for halogenated VOCs, metals, PCBs, gross radioactivity, and tritium. This information is not included in the GEMINI database, which is summarized in Section 3.5.2. The analyses indicated concentrations below detection limits for all analytes except tritium, which was present at trace levels in soil pore water. The tritium, which was present at levels below drinking water standards, was attributed at the time to slightly contaminated soil brought to the area as fill material. Tritium has not been detected at levels of concern in groundwater samples from the area.

Aerial photographs of the Livermore Site taken by LLNL and covering the period from 1949 to 1985 were examined (DOE 1998a). Photographs showing the entire site were available for most years, with several focused on the northeastern quadrant or portions thereof. The aerial photographs commonly show soil disturbances throughout the Livermore Site. The nature of soil disturbances was generally not identifiable on the photographs, although areas that were suspected of containing buried material were further investigated. The photographs showed the appearance and operation of the ETCL from about 1954 to 1974, which was thoroughly investigated in 1989 (Thorpe et al. 1990). A May 1964 photograph showed soil disturbance in the area where the capacitor landfill was discovered in the NIF Construction Area in 1997. That 
landfill appears to be covered over in 1965. This area has been investigated since 1989, although no buried debris or PCB soil contamination was found until 1997. After the capacitor landfill was discovered in the NIF Construction Area, it was determined that this was the same location as the disturbed area earlier identified on the 1964 photograph. The capacitor landfill was not discovered during the earlier source investigations because of lack of sufficient information to pinpoint the location accurately. Numerous photographs from about 1960 to 1980 show soil piles and surface changes consistent with the reported soil and debris storage and fill operations in the northeastern quadrant, which affected most of the stipulated areas in the main block (DOE 1998a).

The employee interview process began with the distribution of a letter to all 3,844 LLNL employees who had worked at the site before 1984. That year was selected as a cutoff for possible undocumented waste disposal activities at the site on the basis of document and photo reviews. In addition, the letter was sent to 3,325 retirees. The letter sought a response from anyone with knowledge of waste disposal or burial practices in the northeastern quadrant of the site, including all of the stipulated areas. Of the 107 direct responses received, 18 reflected personal knowledge of waste disposal practices, while 31 more claimed observational or secondhand knowledge. Follow-up of the responses led to 16 in-depth interviews of responders and other identified persons. Interviews were conducted with the aid of site maps and photographs from the period, allowing the interviewees to respond to direct questions about specific features appearing in such records.

The first-hand accounts provided by the interviewees mostly confirmed the operation of the ETCL and possible recollection of the capacitor landfill discovered in the NIF Construction Area in 1997. There were no accounts of any other burial sites that might have involved hazardous materials. The likelihood that the soil piles and surface disturbances observed in the aerial photographs were soil storage and fill operations was also affirmed in the interviews. The previously reported disposal of nonhazardous wastes and debris in ditches in the Northern Boundary Area was also substantiated; there were no reports of disposal of any hazardous materials in this area. All persons with direct knowledge of waste disposal reported that all such activities were conducted within applicable regulations existing at the time.

On the basis of the findings of the document review, aerial photograph review, and personal interviews, areas identified for further study by geophysical surveys according to Paragraph 3 of the Joint Stipulation and Order were narrowed to the Helipad Area, the Northern Boundary Area, and the NIF Construction Area (areas identified as a, c, and g in Paragraph 2 of the Joint Stipulation and Order [see Section 1.3.2]).

\subsubsection{Summary of Phase II Results}

Phase II activities encompassed fieldwork performed in the three areas identified in Phase I for further investigation in conformance with Paragraphs 3-5 of the Joint Stipulation and Order. Fieldwork consisted of conducting geophysical surveys in the areas; placing test 
excavations and borings at suspicious or other appropriate locations; analyzing sediment samples and soil borings; and drilling, developing, and sampling several groundwater monitoring wells in key areas. This increasingly detailed approach was designed to provide wide coverage while focusing resources appropriately. The findings of the Phase II activities for the three areas identified for further investigation under Phase I and for the ETC Area are summarized in the following subsections. The ETC Area was included for Phase II activities after the discovery of residual PCB-contaminated soil there. ${ }^{3}$

\subsubsection{NIF Construction Area}

Several geophysical surveys have been conducted over the past year in the area of the capacitor landfill discovery and around the perimeter of the NIF Construction Area. An electromagnetic induction (EMI) survey was performed on September 9, 1997, near the excavated capacitor pit to identify areas of increased electrical conductivity that might indicate buried metal objects. Readings were taken around the pit and to about $30 \mathrm{~m}(100 \mathrm{ft})$ to the southwest of the pit to depths of about $4.6 \mathrm{~m}(15 \mathrm{ft})$ and $15 \mathrm{~m}(50 \mathrm{ft})$ in separate runs. EMI surveys made it possible to facilitate mapping subsurface conductivity changes and delineate spatial variables resulting from changes in the natural background conditions or from the presence of buried objects. The survey revealed no significant anomalies, thus indicating, in the operators' assessment, that there is a low probability that additional buried metal objects on the scale of the discovered capacitors exist in the area.

A mapped magnetometer survey was conducted along a proposed trench route surrounding the NIF construction site over the period of December 4-9, 1997, by the U.S. Navy, SSPORTS Environmental Detachment. A magnetometer measures the magnetic field strength and responds to the presence of buried ferrous metals that cause local variations in the earth's magnetic field. The instrument used in the survey collected data from both an upper and a more sensitive lower detector to uncover any anomalies from buried metal objects. Over 70 magnetic anomalies were recorded by the lower detector; the number was reduced to 13 with confirmation by the upper detector (SSPORTS 1997). Anomaly number L-41, a fairly distinct and intense signal, was perhaps the most interesting.

A ground-penetrating radar (GPR) instrument used for locating underground utilities was used on December 29, 1997, to confirm the L-41 magnetic anomaly. The transmitted energy in a GPR unit is reflected back to the radar antenna when inhomogeneities in the electrical properties, such as differences in water content, dissolved minerals, clay content, or zones of heavy mineral content, are encountered. Operated in the point-data collection mode, the instrument did not

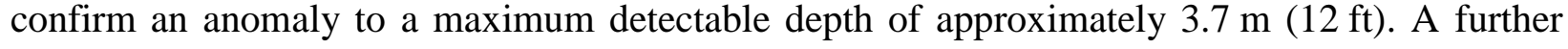

\footnotetext{
3 As discussed in the East Traffic Circle Landfill Closure Report (LLNL 1986), PCB-contaminated capacitors and soil and other hazardous and nonhazardous material were excavated and removed in 1984. The discovery of PCBcontaminated soil in 1998 from the closed ETC Landfill is considered residual contamination and does not indicate the presence of any previously unknown or undiscovered buried hazardous, toxic, or radioactive material.
} 
attempt to confirm the L-41 magnetic anomaly was conducted on February 9, 1998, with an electromagnetic terrain conductivity meter. It was concluded from surveys run along the sides and through the center of the suspect area that no conductivity anomaly was present.

Finally, on March 13, 1998, a second magnetic survey was conducted by the Navy in the area of the original L-41 magnetic anomaly. Again, this survey did not confirm the L-41 magnetic anomaly. On the basis of this and the other unsuccessful attempts to verify the original reading, the L-41 magnetic anomaly was concluded to have been an error (SSPORTS 1998a). It was attributed to one or more of the following factors: edge effects, operator or instrument error, rainy conditions, or near-surface construction debris that were later removed. This conclusion was confirmed when a $0.9-\mathrm{m}(3-\mathrm{ft})$ wide by $4.6-\mathrm{m}(15-\mathrm{ft})$ deep test pit dug at the location of the L-41 magnetic anomaly on April 15, 1998, found no buried objects.

Other intrusive sampling in the NIF Construction Area included the digging (on

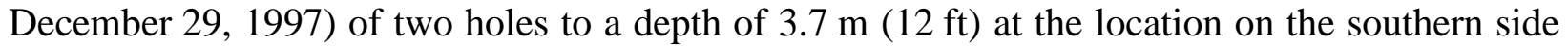
of the site where construction debris had previously been unearthed. Material from the westernmost hole confirmed the presence of debris (concrete, asphalt, wood, and cuttings), while the easternmost hole contained fill material and native soil. This result confirms evidence of use of nonhazardous materials as fill in this area noted in Phase I investigations.

In addition to the described investigation of the L-41 magnetic anomaly found in the original December 1997 magnetic survey, 11 of the other 12 detected anomalies were investigated in January 1998 by drilling boreholes to depths of $6 \mathrm{~m}(20 \mathrm{ft})$ near the locations of the anomalies. Four other boreholes were drilled at random locations along the southern and western sides of the NIF Construction Area along the path of a planned utility trench. Soil or sediment samples were collected from each of the boreholes at depths of 3, 4.6, and $6 \mathrm{~m}(10,15$, and $20 \mathrm{ft}$ ). No buried objects, except for some nails and wire, were encountered in the drilling of any boreholes. Sediment samples were screened for organic vapors, and selected samples were sent to a state-certified laboratory for analysis of halogenated volatile organic compounds (VOCs), PCBs, and dioxins/furans; none were found in any of the samples.

\subsubsection{Helipad and East Traffic Circle Areas}

An EMI survey measuring electrical conductivity was conducted in the Helipad Area on October 1, 1997, in a manner similar to the survey conducted around the capacitor pit in the NIF Construction Area on September 9, 1997. The Helipad survey showed no anomalies that would indicate the presence of large buried metal objects, such as capacitors or drums.

In March 1998, the Navy conducted a magnetometer survey in the Helipad Area (SSPORTS 1998a). Four magnetic anomalies were detected in the vertical gradient survey. Two of the anomalies were attributed to buried utilities, leaving two to be further investigated. On April 6, 1998, boreholes were drilled to a depth of $6 \mathrm{~m}(20 \mathrm{ft})$ at the latter two anomalies, and 
samples were collected at depths of 3, 4.6, and $6 \mathrm{~m}$ (10, 15, and $20 \mathrm{ft}$ ). Sediment (soil) samples were analyzed for halogenated VOCs and PCBs in a state-certified laboratory. All samples were negative. During the drilling, construction debris, including sheetrock and wiring, were encountered near the surface, again confirming the placement of such material as fill in the northeastern quadrant.

Groundwater sampling and analysis was carried out on March 4, April 22, July 20, and July 27, 1998, in six monitor wells installed after September 1997. Three wells in, and near, the Helipad Area (W-1311, W-1401, and W-1416) and three wells in the adjacent East Traffic Circle Area (W-1402, W-1403, and W-1405) screened at three different depths (representing the major hydrostratigraphic units underlying the site) were sampled. The wells are generally west and south, i.e., downgradient, of the NIF Construction Area and the previously excavated PCB capacitor landfill. Samples were analyzed for PCBs, VOCs, tritium, gross alpha and beta activity, and inorganic constituents. Results were negative for PCBs. VOCs, primarily chlorinated ethanes/ethenes, were detected at levels up to 1,900 ppb in the Helipad Area and up to 1,000 ppb in the East Traffic Circle Area. Those levels are consistent with the historical analysis of groundwater impacted by the East Traffic Circle Landfill. Tritium levels were below drinking water standards, and gross alpha and beta levels were near the natural background level. These data will be used in monitoring impacts on water quality from NIF construction and operation. These results, along with sediment and soil data, are presented in the various quarterly reports on stipulated activities. In general, analytes have decreased in concentration since November 1997 in response to nearby cleanup activities (Section 3.6).

While drainage maintenance work was being performed under the East Traffic Circle Drainage Improvement Project, debris was found in the ETC Area in October 1998. Routine analysis of soil samples associated with the uncovered debris detected PCB (Aroclor 1254) contamination in two samples at $98 \mathrm{ppm}$ and $120 \mathrm{ppm}$. A cleanup level of $18 \mathrm{ppm}$ for Aroclor 1254 was agreed to by the CERCLA RPMs (Bainer and Littlejohn 1999). This level is equivalent to the Region 9 Preliminary Remediation Goal (PRG) for Aroclor 1254 in soils at an industrial area. About $230 \mathrm{~m}^{3}\left(300 \mathrm{yd}^{3}\right)$ of affected soil was removed and sent to an off-site EPA-approved CERCLA waste disposal facility in Grandview, Idaho. The storage area where the soil was temporarily stored was scraped and sampled to verify complete removal. An investigation of the area of the PCB (Aroclor 1254) find in the ETC Area was performed in early 1999 to delineate the extent and remove any further contamination above regulatory levels.

After the original removal of contaminated soil, sediment samples from seven boreholes in the ETC Area and two more in the Helipad Area were collected at depths to $6 \mathrm{~m}(20 \mathrm{ft})$. These samples revealed additional PCB contamination in the near surface in an area defined by three of the boreholes in the ETC Area. This contamination was reported as Aroclor 1254. The area was scraped and sampled a total of three times, involving removal of a total of $85 \mathrm{~m}^{3}\left(106 \mathrm{yd}^{3}\right)$ of soil, until the 18-ppm cleanup level agreed upon by the CERCLA RPMs was ultimately achieved in July 1999. Verbal approval was given on July 15 and 16, 1999, by the regulatory agencies to end the excavation and regrade the area (Bainer 1999). 
A magnetometer survey was also performed in and around the ETC Area to locate possible buried waste (SSPORTS 1999). Twenty-three anomalies were identified, and seven of those were determined to warrant subsurface investigation. The latter investigations failed to identify any additional contamination (June 1999 Quarterly Report [DOE 1999c]). DOE has concluded that no buried contaminated objects remain in the ETC.

\subsubsection{Northern Boundary Area}

The Northern Boundary Area is the site of a former garbage trench that was used for disposal of general waste from dumpsters. The trench is oriented east-west and is about $210 \mathrm{~m}$ $(700 \mathrm{ft})$ long, $8.5 \mathrm{~m}(28 \mathrm{ft})$ wide, and $2.7 \mathrm{~m}(9 \mathrm{ft})$ deep. Garbage was placed in the trench to a depth of about $1.8 \mathrm{~m}(6 \mathrm{ft})$ and covered with about $1.8 \mathrm{~m}(6 \mathrm{ft})$ of mounded backfill. The trench was surrounded by a security fence during its operating life (Lindeken 1988).

The Navy conducted a magnetometer survey in this area over the period April 8-14, 1998, to develop a magnetic profile of the area and detect any significant subsurface magnetic anomalies (SSPORTS 1998b). All of the magnetic anomalies identified met the parameters and profiles of existing underground utilities or services in the study area and, therefore, did not warrant any further investigation.

\subsection{CONSEQUENCES OF CONTINUING TO CONSTRUCT AND OPERATE THE NIF}

The Phase I and II investigations, as described in Section 4.1, suggest that there is low likelihood that significant quantities of additional previously unidentified buried hazardous, toxic, or radioactive objects remain in the stipulated areas. This conclusion is based on the results of the series of increasingly detailed inquiries conducted to identify and investigate suspicious areas (summarized in Section 4.1). This approach ensured wide coverage while providing convincing evidence of the absence of any further undocumented buried hazardous, toxic, or radioactive objects in reasonably likely areas. Investigation methods relied largely on historical records, aerial photographs, personal interviews, and geophysical surveys to detect buried metal objects, such as capacitors or drums, that would be associated with waste burial. The burial of substantial quantities of wastes without such metallic containers is deemed unlikely. The absence of buried metallic waste containers or wastes was verified by borings at locations of survey anomalies. Further indication of the absence of buried wastes comes from analysis of soil samples collected from borings and groundwater samples collected in the vicinity and downgradient of potential source areas. Groundwater samples have consistently shown the absence of such sources and will continue to be monitored into the foreseeable future to detect any emerging sources.

Phase I and Phase II investigations indicated that groundwater in the northeastern quadrant is not currently being affected by buried hazardous, toxic, or radioactive material (Table 3.2). As part of Phase II activity, monitoring wells W-1311, W-1401, W-1402, W-1403, 
$\mathrm{W}-1405$, and W-1416 were fully developed and sampled for contaminants of concern. All constituents were below their MCLs (DOE 1998b) (Section 3.6, including Table 3.2). PCBs were not detected in the sampling. Groundwater samples have consistently shown the absence of PCB contamination downgradient from soils previously contaminated with buried PCB waste and will continue to be monitored into the foreseeable future.

On the basis of the above findings, it is concluded that the only sources of previously unknown or undiscovered buried hazardous, toxic, or radioactive waste existing in the northeastern quadrant at the time NIF construction began were the capacitor landfill discovered in September 1997 and the elevated concentrations of residual PCBs discovered in soil in the ETC Area in 1998. These sites were cleaned up to action levels agreed upon by the CERCLA RPMs, thereby reducing heretofore unsuspected contamination in soils at the NIF Construction Area and the ETC Area.

\subsubsection{Impacts from Soil Suspended in Ambient Air from Capacitor Removal during NIF Construction}

The findings under the Phase I and II investigations indicate that the capacitor landfill discovered in September 1997 was the only source of previously unknown or undiscovered buried hazardous, toxic, or radioactive waste in any of the areas identified under the Joint Stipulation and Order since the NIF construction groundbreaking. Because the discovery and excavation of the PCB capacitor landfill in 1997 was a direct result of the NIF construction activities and occurred in what was later designated as a stipulated area (NIF Construction Area), and because the discovery and cleanup of PCB-contaminated soil in the ETC Area (unrelated to NIF construction) in 1998 and 1999 was also in a stipulated area, possible impacts associated with the contamination and cleanup in these areas were analyzed. ${ }^{4}$ For both areas, potential health impacts from dust generated during excavation of contaminated soil were analyzed in some detail. The assessed impacts are associated with the CERCLA cleanup of contaminated soil during a period of NIF construction. The impacts resulting from disturbance and suspension of PCB-contaminated soil from cleanup activities during this period were evaluated, and resulting health risk was then assessed in terms of latent cancer risk from inhalation of the PCBcontaminated fugitive dust.

Dust emission rates from heavy equipment operation were estimated from EPA standards (EPA 1995a) and from a description of the excavation activity. Dispersion of the emitted dust, which was assumed to contain PCB residuals at the highest concentration detected in the excavated soils, was modeled with a conservative screening approach, employing the SCREEN3 model consistent with EPA guidance (1995b). Conservative meteorological conditions were assumed with a dispersion model (SCREEN3) designed to produce conservative results

\footnotetext{
4 The buried waste and associated contaminated soil discovered in the NIF Construction Area and the ETC Area are nonroutine legacy waste not connected with the NIF project.
} 
(e.g., estimates of maximum potential exposure levels). ${ }^{5}$ Exposure to PCBs on the respirable $\left(\mathrm{PM}_{10}\right)$ fraction of dust via inhalation by a hypothetical member of the public standing at the nearest point of public access was then estimated. The exposure scenario assumed that an adult stood at the fence line for the entire duration of excavation for each action. Calculated cancer risks (chance per year), estimated for this highly conservative PCB exposure scenario by using a cancer slope factor from EPA's IRIS database for inhalation, were $1 \times 10^{-9}(1$ in $1,000,000,000)$ and $4 \times 10^{-9}$ ( 1 in $\left.250,000,000\right)$ for the NIF Construction Area and ETC Area cleanup actions, respectively. These calculated cancer risks from dust are, respectively, 1,000 times and 250 times smaller than the EPA point of departure for determining remediation goals $-1 \times 10^{-6}$ ( 1 in $1,000,000)$ as established in 40 CFR Part 300. Noncancer impacts were estimated as hazard quotients of 0.08 and 0.6 for the NIF Construction Area and ETC Area, respectively. Both are below a threshold value of 1.0 for the reference dose for chronic exposure (EPA IRIS, Aroclor 1254). The reference dose applies to long-term exposure, while the PCB hazard quantities calculated for the NIF Construction Area and ETC Area are short term, adding an additional level of conservatism to the estimates. The details of the dispersion modeling and risk estimates are presented in Appendix A.

Workers involved in the two cleanup actions were protected from dust-borne PCB exposures through the use of appropriate personal protective equipment and safe work practices. Excavation equipment used in the actions was carefully decontaminated and verified clean. Areas where PCB soils were stored or stockpiled were scraped and sampled to verify complete removal of contamination.

Given the results of the analyses discussed here and the good work practices used by cleanup workers, health impacts to the public and involved workers from the execution of the two PCB remedial actions are estimated to be very low, well below applicable levels of concern.

\subsubsection{Impacts to Soil from Operation of the NIF}

Impacts on soil resources from the operation of the NIF in the current context would relate to any increased release of any existing buried hazardous, toxic, or radioactive wastes resulting from facility operations, or any releases of such wastes to soils from facility operations. Potential impacts of either type are highly unlikely for two reasons. First, the results of Phase I and Phase II investigations under the Joint Stipulation and Order indicate that there is low probability that undiscovered buried hazardous, toxic, or radioactive wastes exist in the vicinity of the facility. Second, evaluations of environmental, safety, and health considerations conducted during the design of the facility (LLNL 1994b) and during subsequent environmental analysis (DOE 1996a) indicate that emissions of material effluents or radiation that could contaminate soils in the NIF site area will be extremely small or nonexistent during NIF operations. Neither liquids nor solids would be discharged to or disposed of in the NIF site area. Thus, facility

5 Thus, use of the model results in estimating that PCB exposure levels would be substantially higher than what would actually be expected to occur. 
operations will neither increase any presently existing impacts to soil nor result in additional contamination of soil.

\subsubsection{Impacts from Soil Contaminant Migration to Groundwater during Construction and Operation of the NIF}

None of the activities for construction of NIF would normally affect groundwater under the stipulated areas at the Livermore Site. Construction and operation of the NIF would not require use of groundwater, and there would be no contaminant discharges from the surface to groundwater. With the ongoing remediation activities taking place in these study areas, groundwater quality would, therefore, be expected to improve with time (DOE 1996). The potential future impacts to groundwater from any potential remaining PCB residues in soil are evaluated below.

Figure 4.1 shows the approximate locations of 112 capacitors containing PCBs that were unearthed at the NIF Construction Area in the northeastern portion of the Livermore Site (Bainer and Berg 1998). The capacitors and about 694 metric tons (766 short tons) of PCB-contaminated soil were removed and managed in full consultation with the CERCLA RPMs. The highest PCB concentration in the excavated soil was $66 \mathrm{ppm}$. After excavation, 12 evenly spaced soil samples along the perimeter of the pit floor, 6 samples along the centerline of the pit floor, and 5 surface soil samples around the outside of the pit showed residual PCB levels in soil less than $1 \mathrm{ppm}$. Because construction activities at the NIF resulted in the unearthing and discovery of the PCBcontaining capacitors, a groundwater analysis of potential impacts is included below. However, detailed analyses for the other contaminants of concern in the groundwater discussed in detail in Section 3.4.3 (TCE, PCE, carbon tetrachloride, Freon 11, chromium VI, and tritium) were not performed because none of the NIF construction activities had a direct disturbance that involved a discovery of these constituents, and none of the sediment samples taken under Phase II activities found any of these constituents.

As discussed in Section 4.1.2.2, about $230 \mathrm{~m}^{3}\left(300 \mathrm{yd}^{3}\right)$ of PCB-contaminated soils was removed from the ETC Area. A cleanup level of $18 \mathrm{ppm}$ was approved by the CERCLA RPMs. Because of similarities in the hydrogeology between the NIF Construction Area and the ETC Area, rates of movement to groundwater of residual PCB contamination in the ETC soil are expected to be similar to the rates of movement to groundwater of PCBs in the NIF Construction Area and should scale directly with the soil concentration. However, since residual PCB concentrations are below $18 \mathrm{ppm}$ in the ETC Area and below $1 \mathrm{ppm}$ in the NIF Construction Area, potential groundwater concentrations derived from PCB soil contamination in the ETC Area would be about 18 times greater than potential groundwater concentrations derived from PCB contamination in the NIF Construction Area.

To calculate the potential impacts of the residual PCBs in the soil on groundwater, a mathematical model for porous media transport and groundwater mixing was employed (see 


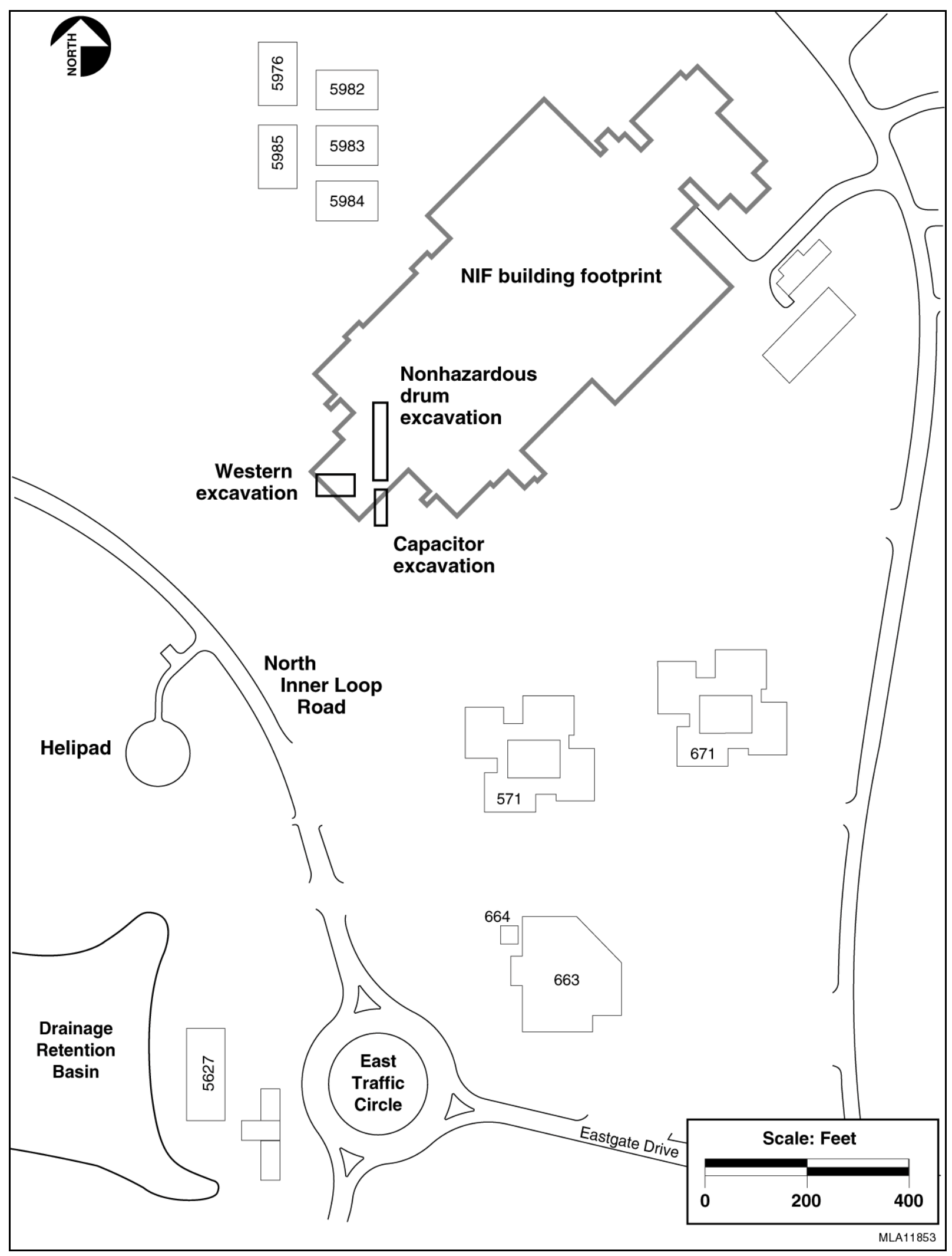

FIGURE 4.1 Locations of the Capacitor, Drum, and Western Excavations at the NIF Construction Site and Location of the East Traffic Circle 
Appendix B). For this analysis, it was assumed that the remaining PCB material in the soil dissolves under the influence of infiltrating precipitation and is transported with soil water vertically downward to the underlying water table. Because of the length of the path that must be traveled (about $13 \mathrm{~m}$ [43 ft]) and sorption, the concentration of dissolved PCB is a complex function of both time and space. At the water table, the contaminated soil water mixes with initially clean groundwater in the saturated zone. Impacts of the soil PCB concentrations were evaluated by comparing the maximum estimated groundwater PCB values with the MCL of $0.0005 \mathrm{ppm}$.

A number of simplifying, conservative assumptions (i.e., assumptions that lead to predictions that have greater impacts than those that would actually be expected to occur) were made for performing the calculations for the above referenced model. These assumptions included the following:

- $\quad$ PCB soil concentrations are at a level of 1 ppm over a depth of $0.3 \mathrm{~m}(1 \mathrm{ft})$;

- The PCB is nondecaying and does not degrade along its flow path to the water table;

- The PCB in the soil was composed entirely of Aroclor 1242, the PCB that has the highest solubility and undergoes the least sorption;

- The concentration of Aroclor 1242 in the soil water in the contaminated zone is equal to the solubility limit of the PCB;

- Transport of Aroclor 1242 occurs only vertically; and

- The infiltration velocity of the dissolved Aroclor is equal to the average annual groundwater recharge at the site. (Maximum annual discharge is not known and would be inappropriate for modeling concentrations over a 200,000-year period.)

Site-specific parameters required to solve the transport equation used for this analysis are given in Appendix B. In addition, that appendix also describes the one-dimensional solution to the advection/dispersion equation used for the analysis.

Figure 4.2 shows the concentration of PCB (Aroclor 1242) at the water table divided by its concentration at the point of dissolution (conservatively assumed to be equal to the Aroclor solubility) as a function of time. This breakthrough curve indicates that a maximum normalized concentration of about 0.001 would occur in about 140,000 years, a period of time much longer than the time estimated for the PCB (Aroclor 1242) to dissolve completely from the soil 


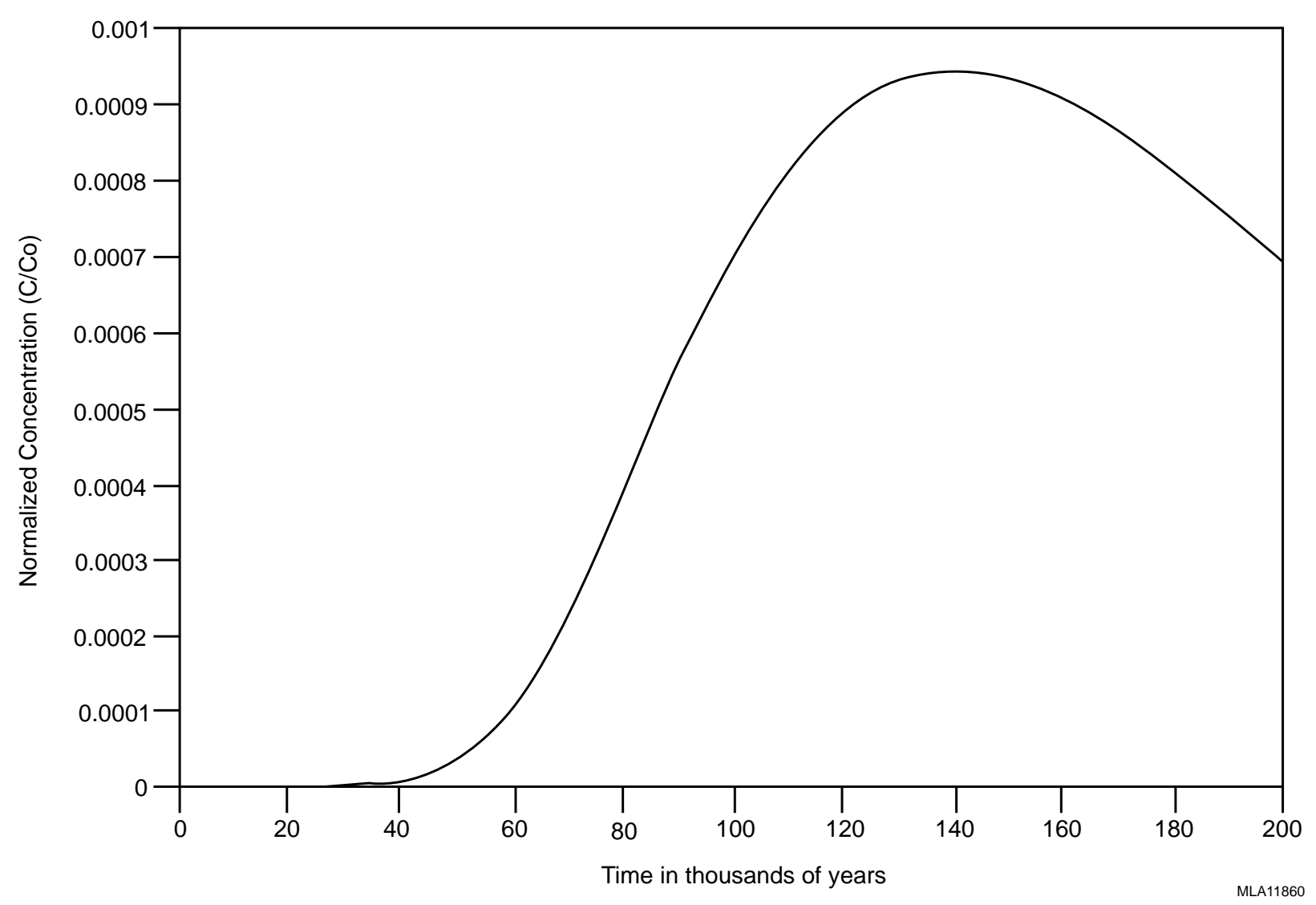

FIGURE 4.2 Water Table Breakthrough Curve for PCB (Aroclor 1242) at the NIF Construction Site

(160 years) (Appendix B). This long period of time is primarily caused by the length of the path from the residual PCB soil zone to the water table and the high degree of sorption expected for the PCB (retardation coefficient ${ }^{6}$ approximately equal to 500) (see Appendix B).

To obtain an actual concentration in the groundwater recharge from the above normalized value, the 0.001 value must be multiplied by the Aroclor solubility $\left(1.0 \times 10^{-7} \mathrm{~g} / \mathrm{cm}^{3}\right)$ (Appendix B). The resulting maximum concentration of PCB at the water table in about 140,000 years would, therefore, be about $0.0001 \mathrm{ppm}\left(1.0 \times 10^{-10} \mathrm{~g} / \mathrm{cm}^{3}\right)$. This value is about five times less than the EPA maximum contaminant level (MCL) of $0.0005 \mathrm{ppm}$ $\left(5.0 \times 10^{-10} \mathrm{~g} / \mathrm{cm}^{3}\right)($ EPA 1994). The conservative assumptions listed above make it likely that this number is an overestimate.

After reaching the groundwater, the dissolved $\mathrm{PCB}$ will be diluted by mixing with initially clean groundwater. A simple mixing model (Appendix B) for site-specific conditions

6 The retardation coefficient is the ratio of the rate of groundwater movement divided by the rate of movement of a chemical dissolved in the groundwater. A large retardation coefficient indicates that the chemical moves much more slowly than the groundwater. 
indicates that a dilution factor of about 40 would occur over the thickness of the saturated zone

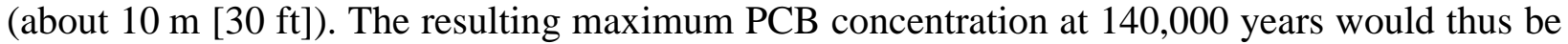
about $2.5 \times 10^{-12} \mathrm{~g} / \mathrm{cm}^{3}(0.0000025 \mathrm{ppm})$. This value is conservatively estimated to be a factor of 200 smaller than, or about $0.5 \%$ of, the current EPA drinking water MCL.

As mentioned previously, groundwater concentrations of PCB derived from contaminated soils in the ETC Area would be about 18 times larger than the values for the NIF Construction Area. The concentration would thus be about $0.000045 \mathrm{ppm}\left(4.5 \times 10^{-11} \mathrm{~g} / \mathrm{cm}^{3}\right)$, which is less than $1 \%$ of the drinking water MCL.

The maximum PCB concentrations predicted in the previous section on the basis of conservative assumptions would be very low and less than the MCL. The time to reach this maximum concentration would be very long (maximum PCB concentrations of $0.0000025 \mathrm{ppm}$ and $0.0001 \mathrm{ppm}$ would not be reached for about 140,000 years) and below the MCL of $0.0005 \mathrm{ppm}$ for drinking water. The soil cleanup level of $1 \mathrm{ppm}$ at the capacitor landfill in the NIF Construction Area and $18 \mathrm{ppm}$ at the ETC Area will provide an environmentally safe level. This conclusion is consistent with cleanup guidelines followed at the landfill and discussed in the Action Memorandum (Bainer and Berg 1998). Because of the very low levels of PCBs predicted to reach groundwater and the fact that they are much less than the drinking water MCL guideline, no risk-based assessment of health effects were performed. The existing information is sufficient to conclude that following remediation, the PCB contamination discovered during NIF construction would not adversely affect human health.

\subsubsection{Impacts to Groundwater from Operation of the NIF}

Operation of the NIF would not result in any direct release of hazardous, toxic, or radioactive materials to groundwater at LLNL (DOE 1996). Because Phase II investigations did not identify any new sources of hazardous, toxic, or radioactive materials at the NIF site area, operation of the NIF would not result in releases of buried hazardous, toxic, or radioactive wastes to groundwater. By the same analysis used for soils, such potential impacts to groundwater from operation of the NIF are not expected. First, recent investigations have shown that there is low probability of residual buried hazardous, toxic, or radioactive waste in the vicinity of the facility. Second, evaluations performed during scoping the NIF PSA, based on facility design, concluded that little or no material effluents or radiation will be emitted from NIF during operation that could impact groundwater.

\subsection{CONSEQUENCES OF CEASING NIF CONSTRUCTION}

Although DOE does not consider the no action alternative of ceasing NIF construction to be reasonable (Section 2.1.2), the impacts that are expected from such an action are discussed 
here. Upon ceasing NIF construction, DOE could take one of the following two actions: (1) complete construction of the buildings for other use, which would require redesign of the building interiors, or (2) demolish the NIF structures and return the site to a brownfield condition. In either case, the impacts of any remaining residual PCB contamination in Stipulated Areas would remain the same as for the preferred alternative (to continue construction and operation of NIF) for soils, groundwater, and health and safety. The recently discovered PCBs in the NIF Construction Area and the residual PCB contamination in the ETC Area have been identified and removed, and the surveys conducted pursuant to the Joint Stipulation and Order indicate that is highly unlikely that further contamination would be found in the future.

In order to use the NIF structures for another purpose, construction of the buildings would be completed. Conventional NIF construction is about $80 \%$ complete, and site preparation and excavation are complete. The NIF facility has specialized features, including (1) massive vibration-free structures for lasers; (2) a clean room for lasers; (3) specialized shielding and ventilation; (4) a target chamber $9 \mathrm{~m} \mathrm{(30-ft)} \mathrm{in} \mathrm{diameter;} \mathrm{and} \mathrm{(5)} \mathrm{seismic} \mathrm{resistant} \mathrm{design.} \mathrm{These}$ features make the facility most suitable for another research effort requiring laser and/or radiological capabilities. The NIF is being constructed as a nonhazardous, radiological facility; it would not be a nuclear facility. Modifications to support a new research effort would be added work. The use of the NIF for an office building, light laboratories, or manufacturing use would require major redesign and significant modifications beyond those required for use by another research program. Such a use is not considered likely.

Impacts of existing and planned programs, including laser research and radiological activities have been analyzed in a Supplement Analysis (SA) (DOE 1999a) for continued operation of LLNL. The SA assesses the impacts on human health and the environment of recent changes in existing programs and planned programs. The SA compares the impacts of new and planned programs and facilities at LLNL to the impacts assessed in the LLNL sitewide EIS (DOE 1992).

If DOE ceased construction of NIF and all constructed features were demolished, the site could be returned to a brownfield condition. The specialized nature of the building includes

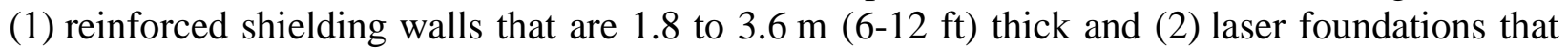

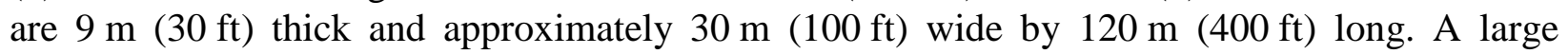
workforce with heavy equipment would be required to demolish existing structures and return the site to its original condition. About 4,400 $\mathrm{m}^{3}$ (about 5,800 $\mathrm{yd}^{3}$ ) of nonhazardous waste would be produced and disposed of off-site. Fill for the excavations would be obtained from an off-site source. The impacts of demolishing NIF would be due to additional site excavation needed to remove building foundations, transportation of nonhazardous wastes to an off-site disposal facility, and transportation of fill material from off-site sources to the NIF Construction Area. The type of activities required for demolition would be similar to the activities required to decontaminate and decommission NIF, as discussed in the SSM PEIS, Appendix I (DOE 1996a). However, no radiological contamination would be present. 
Briefly, the impacts of the NIF no action alternative as ceasing construction are:

- The construction workforce would continue until the buildings were either made suitable for a new use or the buildings were demolished and excavations filled. Construction workers would be employed for a longer period for demolition of NIF than if NIF were reused or completed for operations. Preparation of NIF buildings for reuse would continue construction employment for a longer period than completion of NIF for operations, but for a shorter period than demolition. NIF operations would support a large workforce, which would keep LLNL workforce numbers stable in the foreseeable future. However, LLNL workforce and payroll would decline for both the reuse and demolition alternatives, because NIF workers would not be employed. Reduced employment and payroll would have an adverse socioeconomic effect in the Tri-Valley area.

- Remodeling the building for another use would increase the time construction and transportation workers were at risk of occupational injuries. However, demolishing NIF and transporting wastes and fill would require the longest time and greatest effort. More workers would be injured during demolition of NIF than for the other alternatives.

- Demolition would generate up to $4,400 \mathrm{~m}^{3}$ (about 5,800 $\mathrm{yd}^{3}$ ) of nonhazardous solid wastes that would be disposed of at an off-site facility. Fill for NIF excavations would come from off-site sources. Alternative use of NIF would produce wastes from remodeling, in addition to wastes generated by completion of the NIF buildings. For both alternatives, some materials may be sold as scrap.

- Alternative use of NIF for another scientific program would use hazardous materials for equipment cleaning and other research activities similar to how hazardous materials would be used for NIF operations. Risks to workers and the public from hazardous materials would be small and within applicable regulations and guidelines. Use of hazardous materials would be regulated by the Occupational Safety and Health Administration and by LLNL management activities and would be similar for both alternatives. Risks from hazardous materials at the NIF facility are addressed in the SSM PEIS (DOE 1996a). If the NIF structures were demolished, risks to human health and safety from hazardous mateials would be absent.

- Alternative use of NIF for another scientific program could include radiological doses to workers and the public that are likely to be small and, less than, or greater than applicable regulations and guidelines. This impact could be similar to the impact of operating NIF as described in the SSM PEIS 
(DOE 1996a). If the NIF structures were demolished, there would be no radiological doses to workers and the public.

- Demolishing the buildings would result in additional truck traffic (see bullet 3 above) because wastes would be taken off-site for disposal and fill would be delivered from off-site sources. Truck traffic from waste removal and fill delivery could adversely affect nests of the white-tailed kite, a state-protected species, as described in the impact analysis for NIF construction (DOE 1996a). This species nests near the East Gate entrance to the Livermore Site. Activities from demolition would be conducted in consultation with appropriate regulatory agencies. Fewer such impacts would result from the other alternatives, because much less bulk materials would be transported.

- Demolition activities, including removing structures and filling and grading the site, would produce dusts, including $\mathrm{PM}_{10}$ for a longer period than either completing NIF for operations or reuse. The Livermore region is not in attainment for this criteria pollutant (DOE 1996a). Best available technology would be used to reduce such dust emissions to the extent possible. Because of cleanup activities described in this SEIS, potential contaminant levels in dusts would be below levels of concern, and impacts to human health would be below those described for site cleanup.

- Demolition, filling, and grading might further disturb paleontological resources that were left in place during NIF construction. If such resources were found, potential impacts would be mitigated in consultation with appropriate authorities. Neither completion of NIF for operations nor reuse of NIF would involve additional excavation, filling, and grading.

In addition to the direct impacts described above, ceasing construction of NIF at LLNL could result in the indirect impacts associated with constructing and operating NIF at another DOE site (see Section 2.1.2). The NIF PSA contained in the SSM PEIS (DOE 1996a) analyzed the impacts of constructing and operating the NIF at each of the following additional sites: Los Alamos National Laboratory and Sandia National Laboratories, both in New Mexico; and the Nevada Test Site.

\subsection{CUMULATIVE IMPACTS}

This section evaluates the contribution of any incremental impacts from potential or confirmed buried material when evaluated in conjunction with similar impacts to the same human and ecological receptors from regional sources. The purpose of evaluating such cumulative impacts is to weigh the effect of the incremental impacts from the evaluated action in 
concert with other such impacts and to determine whether impacts that may be small in isolation may be of concern when considered in total with other impacts.

The sitewide EIS prepared in 1992 for LLNL (DOE 1992) identified the combined and cumulative impacts of site operations projected for the period from then until the year 2002. DOE has recently prepared a Supplement Analysis to determine whether the sitewide EIS should be supplemented (DOE 1999a). Furthermore, the SSM PEIS (DOE 1996) discusses cumulative impacts of NIF construction and operation.

This SEIS concludes that the impacts from potential buried hazardous, toxic, or radioactive materials are below applicable levels of concern as defined by EPA Region 9 Industrial Preliminary Remediation Goals (PRGs) and drinking water standards (MCLs). Investigations conducted pursuant to the Joint Stipulation and Order demonstrate that there is a low likelihood that more buried materials will be found in the area. This conclusion was based on historical records, interviews, and geophysical and monitoring studies. The effective soil cleanup levels of $1 \mathrm{ppm}$ at the capacitor landfill discovered in the NIF Construction Area and $18 \mathrm{ppm}$ at the ETC Area are protective of groundwater and human health. Groundwater concentrations of PCBs from remaining contamination at $1 \mathrm{ppm}$ in soil would reach $0.0001 \mathrm{ppm}$ at the water table (maximum concentration) and $0.0000025 \mathrm{ppm}$ in the groundwater in about 140,000 years. These values are, respectively, 5 and 200 times less than the EPA MCL of 0.0005 ppm. Potential exposures of the public from cleanup of the PCB landfill in the NIF Construction Area and the residual PCB contamination in the ETC Area would have been orders of magnitude below levels of concern established by the EPA (Section 4.2 and Appendix A). No adverse effects on human health would have resulted from either cleanup action.

Because of the historical use of the Livermore Site and past practices used for the handling, storage, and disposal of hazardous materials, it is common to encounter low levels of contaminated soils during excavations throughout the site. Being a Superfund Site on the National Priorities List implies that various levels of contamination are likely to be found during normal construction activities. LLNL has in place procedures that dictate what needs to be done when contaminated soil is encountered. The disposition of contaminated soils is dependent on the concentration of the individual contaminants encountered. On the basis of source investigations and subsurface geophysical studies, it is not likely that additional buried hazardous objects will be discovered in the areas identified in the Joint Stipulation and Order. It is possible, however, that future Livermore Site grading activities or site improvements may identify soil contamination such as occurred at the ETC Area. As soil contamination is identified, it will be handled through permitted processes as determined by LLNL's Operations and Regulatory Affairs and Hazardous Waste Management Divisions. CERCLA RPMs will be notified or consulted as appropriate.

Near the NIF site, generators of material releases and wastes include the Livermore Site and Sandia National Laboratories-California (SNL-CA). Operations of these facilities have been described in the 1992 sitewide EIS (DOE 1992) and were reevaluated in the Supplement Analysis (DOE 1999a). Both of these documents discuss waste generation and hazardous and 
toxic materials. LLNL's 1997 Site Environmental Report (LLNL 1998) indicates that site operations result in few, low-level, and controlled releases of pollutants. Neither LLNL nor SNL-CA operations produce routine releases of PCBs. No PCB contamination is known from SNL-CA. Locations at LLNL where past activities may have resulted in buried wastes or materials or contaminated soil or groundwater are undergoing active remediation. This remediation at LLNL is performed under CERCLA in full consultation with the RPMs. These remedial activities at LLNL may also release particulates $\left(\mathrm{PM}_{10}\right)$ that contain PCBs. The exposure of the public and workers from remediation of contaminated soil, such as the capacitor landfill, has been shown in this SEIS to be well below levels at which health effects could be reasonably expected.

The Livermore Site is in the San Francisco Bay watershed. Some surface waters from the Livermore Site recharge the Amador Valley groundwater basin, where some water is withdrawn by Zone 7 for domestic supply. Wastewater is discharged to the Central Bay via the East Bay Municipal Utility District outfall. Outflow from the valley basin is also withdrawn by the Alameda County Water District for domestic supplies, and some flows into the bay. Monitoring of sediments and PCBs in the bay has indicated the presence of PCBs in fish and sediment. The sources of these PCBs are various industrial activities in the watersheds of the bay. The San Francisco Estuary Regional Monitoring Program for Trace Substances gives concentrations of PCBs in fish in the South Bay (http://www.sfei.org/rmp/rmpother.htm). The California EPA Office of Environmental Health Hazard Assessment (OEHHA) reports a long-term trend of decreasing PCB levels. The agency has issued an interim consumption advisory to protect human health (http://www.oehha.org/scientific/pcb.htm). Removal of PCB-containing capacitors and contaminated soils at the Livermore Site would reduce the potential for PCBs to enter drainageways at the Livermore Site, a beneficial impact for the regional groundwater resources. 
[This page intentionally left blank.] 


\section{REFERENCES}

Bainer, B., and Littlejohn, J., 1999, "LLNL Livermore Site April 15, 1999, Remedial Project Managers’ Meeting Summary,” Livermore, Calif., Aug. 30.

Bainer, R.W., 1999, East Traffic Circle Soil Removal, internal memo from Bainer, Environmental Restoration Division, to Richard Scott, DOE Oakland Operations Office, Oakland, Calif., Aug. 3.

Bainer, R.W., and L.L. Berg (eds.), 1998, Action Memorandum for an Emergency Removal Action at the National Ignition Facility Construction Site, Lawrence Livermore National Laboratory Livermore Site, UCRL-AR-128728, U.S. Department of Energy, Oakland Operations Office, Oakland, Calif., and Lawrence Livermore National Laboratory, Livermore, Calif., Feb.

Berg, L.L., et al., 1997, Five-Year Review for the Lawrence Livermore National Laboratory Livermore Site, UCRL-AR-126935, Livermore, Calif., Nov.

DOE: See U.S. Department of Energy.

Dreicer, M., 1983, internal memo Re: "Environmental Survey of the Proposed Human Resources Complex Area," from Dreicer to J. Cramer, Lawrence Livermore National Laboratory, Livermore, Calif.

Dreicer, M., 1985, Preliminary Report on the Past and Present Uses, Storage, and Disposal of Hazardous Materials and Wastes on the Lawrence Livermore National Laboratory, UCID20442 Draft, Lawrence Livermore National Laboratory, Livermore, Calif., May.

Lawrence Livermore National Laboratory, 1986, East Traffic Circle Landfill Closure Report, Livermore, Calif., Jan.

Lawrence Livermore National Laboratory, 1994a, Remedial Design Report No. 3 for Treatment Facilities $D$ and E, Lawrence Livermore National Laboratory Livermore Site, UCRL-AR113880, Livermore, Calif.

Lawrence Livermore National Laboratory, 1994b, Energy and Technology Review, UCRL52000-94-12, Livermore, Calif., Dec.

Lawrence Livermore National Laboratory, 1998, 1997 Site Environmental Report, UCRL50027-97, Livermore, Calif., Sept. 
Lindeken, C., 1988, internal memorandum from Lindeken to W. McConachie, Lawrence Livermore National Laboratory, Livermore, Calif., March 1.

LLNL: See Lawrence Livermore National Laboratory.

McConachie, W., et al., 1986, East Traffic Circle Landfill Closure Report, Lawrence Livermore National Laboratory, Livermore, Calif.

Picel, K., 1999, unpublished information, Argonne National Laboratory, Argonne, Ill., Sept.

SSPORTS, 1997, Geometrics G858G Cesium Magnetometer Survey, National Ignition Facility, Lawrence Livermore National Laboratory, Livermore, California, U.S. Navy, SSPORTS Environmental Detachment, Dec. 12.

SSPORTS, 1998a, Summary Report: Magnetometer Survey of the Area between the Drainage Retention Basin and Southern Perimeter Fencing of the National Ignition Facility, Lawrence Livermore National Laboratory, Livermore, California, U.S. Navy, SSPORTS Environmental Detachment, March 19.

SSPORTS, 1998b, Summary Report: Magnetometer Survey of the Northern Boundary Area between the North Outer Loop Road and the Northern Perimeter Fencing of the National Ignition Facility, Lawrence Livermore National Laboratory, Livermore, California, U.S. Navy, SSPORTS Environmental Detachment, June 1.

SSPORTS, 1999, Summary Report: Magnetometer Survey of the East Traffic Circle/East Gate Drive Area, Lawrence Livermore National Laboratory, Livermore, California, U.S. Navy, SSPORTS Environmental Detachment, April 26.

Stephens and Associates, Inc., 1996, letter report to Lawrence Livermore National Laboratory, Sept. 16.

Thorpe, R.K., et al., 1990, CERCLA Remedial Investigations Report for the LLNL Livermore Site, UCAR-10299, Vols. 1-5, Lawrence Livermore National Laboratory, Livermore, Calif.

Tomasko, D., and J. Quinn, 1999, unpublished data, Argonne National Laboratory, May.

U.S. Department of Energy, 1992, Final Environmental Impact Statement and Environmental Impact Report for Continued Operation of Lawrence Livermore National Laboratory and Sandia National Laboratories, Livermore, DOE/EIS-0157, Vols. I-V, Oakland Operations Office, Oakland, Calif., Aug. 
U.S. Department of Energy, 1996a, Final Programmatic Environmental Impact Statement for Stockpile Stewardship and Management, DOE/EIS-0236, Washington, D.C.

U.S. Department of Energy, 1996b, Technology Basis and Site Comparison Evaluation for the National Ignition Facility, Oakland Operations Office, Oakland Calif., September.

U.S. Department of Energy, 1997, November 1997 Quarterly Report, Nov.

U.S. Department of Energy, 1998a, February 1998 Quarterly Report, Feb.

U.S. Department of Energy, 1998b, May 1998 Quarterly Report, May.

U.S. Department of Energy, 1998c, August 1998 Quarterly Report, Aug.

U.S. Department of Energy, 1998d, November 1998 Quarterly Report, Nov.

U.S. Department of Energy, 1999a, Supplement Analysis for Continued Operation of Lawrence Livermore National Laboratory and Sandia National Laboratories, Livermore, DOE/EIS-0157SA-01, Vols. 1 and 2, Oakland Operations Office, Oakland, Calif., March.

U.S. Department of Energy, 1999b, March 1999 Quarterly Report, March.

U.S. Department of Energy, 1999c, June 1999 Quarterly Report, June.

U.S. Environmental Protection Agency, 1994, Drinking Water Regulations and Health Advisories, Office of Water, Washington, D.C.

U.S. Environmental Protection Agency, 1995a, Compilation of Air Pollutant Emission Factors, AP-42, 5th Edition, Office of Air Quality Planning Standards, Research Triangle Park, N.C., Sept.

U.S. Environmental Protection Agency, 1995b, SCREEN3 Model User's Guide, EPA-454/B-95004, Office of Air Quality Planning Standards, Research Triangle Park, N.C., Sept.

Vogele, T.J., et al., 1996, Simulation of Soil Vapor Extraction at Building 518 Lawrence Livermore National Laboratory Livermore Site, UCRL-AR-124995, Livermore, Calif., Sept. 
[This page intentionally left blank.] 
APPENDIX A:

POTENTIAL HEALTH IMPACTS FROM EXPOSURE TO PM10-BORNE PCBS FROM RECENT REMEDIATION ACTIONS 
[This page intentionally left blank.] 


\section{APPENDIX A:}

\section{POTENTIAL HEALTH IMPACTS FROM EXPOSURE TO PM $_{10}$-BORNE PCBS FROM RECENT REMEDIATION ACTIONS}

Two recent remedial actions involving soil contaminated with polychlorinated biphenyls (PCBs) are addressed in this Supplemental Environmental Impact Statement. The first action involved the removal of buried capacitors and contaminated soil from an area within the National Ignition Facility (NIF) construction zone at Lawrence Livermore National Laboratory (LLNL) in September 1997. The second involved removal of residual PCB-contaminated soils from the East Traffic Circle (ETC) Area at LLNL discovered during excavation for drainage improvement in October 1998. Both actions involved the excavation and handling of PCB-contaminated soils (Table 3.1) that may have generated emissions of dust-borne PCBs. Because these two actions took place within the SEIS stipulated areas, the potential impacts of conducting the remedial actions were evaluated. The main impact of potential concern would be exposure of members of the public to dust-borne PCBs. In the following sections, such impacts are evaluated through a combined analysis of dust emission and dispersion modeling and PCB intake and toxicity analysis for hypothetical receptors at the site fence line.

\section{A.1 ESTIMATES OF PM10 EMISSIONS AND DISPERSIONS FROM THE NIF CAPACITOR EXCAVATION}

The evaluation of impacts from PCB-contaminated soils associated with the cleanup of buried capacitors that took place over a 10-day period in September 1997 at the NIF construction site involved the analysis of exposures to airborne contaminants generated during excavation and handling of the soils. The major concern is human health risk posed by exposure to PCBcontaminated dust. Accordingly, emissions of $\mathrm{PM}_{10}$, the respirable fraction of dust, generated from the handling of the contaminated soils were examined.

To evaluate potential impacts, $\mathrm{PM}_{10}$ emissions from the action of heavy equipment were first estimated. Standard dust emission factors for generic excavation equipment and conservative meteorological conditions were assumed for these screening-level estimates. The estimated emissions were then used as input for air dispersion modeling to estimate 24-hour maximum concentrations at the closest site boundary. Other miscellaneous PM $_{10}$ sources not directly related to contaminated soils were not considered. The estimated maximum $\mathrm{PM}_{10}$ concentration was then used to estimate human exposure and health impacts (Section A.3). The calculations were based on the conservative assumption that PCB concentrations were equal to the maximum value measured in soil samples from the excavation. 


\section{A.1.1 Description of Occurrence}

During September 3-12, 1997 (5 actual working days), 112 capacitors containing PCBs were unearthed at the NIF construction site located in the northeastern quadrant of the LLNL Livermore Site. The 112 capacitors were removed from an excavated trench approximately $6 \mathrm{~m}$ $(20 \mathrm{ft})$ wide, $21 \mathrm{~m}(70 \mathrm{ft})$ long, and $5.2 \mathrm{~m}(17 \mathrm{ft})$ deep. The capacitors and about 694 metric tons (766 short tons) of PCB-contaminated soil were removed in an emergency removal action executed by DOE/LLNL in accordance with the Comprehensive Environmental Response, Compensation, and Liability Act (CERCLA), as amended by the Superfund Amendments and Reauthorization Act (SARA). This action was accomplished in full coordination with CERCLA Remedial Project Manager (RPMs), who represent the U.S. Environmental Protection Agency (EPA), the California Department of Toxic Substances Control, and the San Francisco Bay Regional Water Quality Board. The capacitors were placed in plastic-lined 55-gal drums and moved to the LLNL's Hazardous Waste Management TSCA storage facility (Bainer and Berg 1998). One excavator was operated full time; one tractor was used for leveling the area part time, and 36 truckloads of contaminated soil were shipped by Laidlaw Environmental Services off-site for incineration at the Laidlaw Environmental Services-Aptus incinerator in Clive, Utah.

\section{A.1.2 Emission Estimations for $\mathbf{P M}_{10}$}

Actual cleanup activities are assumed to have taken place during daytime hours in a work area assumed to be $18 \mathrm{~m}(60 \mathrm{ft})$ by $34 \mathrm{~m}(110 \mathrm{ft})$, with a $6-\mathrm{m}(20-\mathrm{ft})$ wide belt of land encircling the excavated trench. A bulldozer was conservatively assumed to represent an excavator because excavator emission factors are not available in reference sources. The $\mathrm{PM}_{10}$ emissions from an excavator (e.g., backhoe or front shovel) would be lower than those from a bulldozer, because an excavator stays at one location, excavates the soil, dumps it onto the receiving surface for some period of time, and then moves to the next location. A grader is assumed to represent the tractor with scoop that was used to level the general area and for minor cleanups during excavation. Use of a Ford 10/12 $\mathrm{yd}^{3}$ dump truck, which could handle about 18 metric tons (20 short tons) of soil, is assumed. It was conservatively assumed that no dust control measures were applied and no precipitation fell during operations.

Emission factors used to develop the $\mathrm{PM}_{10}$ emission rates were estimated from a standard reference source (EPA 1995a, hereinafter referred to as AP-42). The emission factors estimated for the various activities are presented in Table A.1. The parameters used to estimate uncontrolled emission factors for specific activities are described below.

\section{A.1.2.1 Excavating}

A bulldozer was conservatively assumed to be used for excavation of the PCBcontaminated soils. The predictive equation for bulldozer operations is contained in Section 11.9 
TABLE A.1 Estimated Total PM10 Emissions from PCB-Contaminated Soils Associated with Cleanup Activities at the NIF Site

\begin{tabular}{llllrr}
\hline & & & & \multicolumn{2}{c}{ Uncontrolled Emissions } \\
\cline { 4 - 6 } \multicolumn{1}{c}{ Activity } & Equipment & $\begin{array}{c}\text { Uncontrolled } \\
\text { Emission Factor }\end{array}$ & Activity & $\mathrm{lb}$ & $\mathrm{lb} / \mathrm{d}$ \\
\hline Excavation & Excavator & $2.41 \mathrm{lb} / \mathrm{h}$ & $40 \mathrm{~h}$ & 96.2 & 19.2 \\
Grading & Tractor & $1.54 \mathrm{lb} / \mathrm{VMT}$ & $8.3 \mathrm{mi}$ & 12.9 & 2.6 \\
Unpaved road traffic & Truck & $3.92 \mathrm{lb} / \mathrm{VMT}$ & $1.5 \mathrm{mi}$ & 5.9 & 1.2 \\
Dumping & - & $0.00018 \mathrm{lb} /$ ton & $766 \mathrm{ton}$ & 1.0 & 0.2 \\
Total & & & & 116 & 23.2 \\
\hline
\end{tabular}

a Conversions:

To convert from pounds to kilograms, multiply by 0.45 .

To convert from miles to kilometers, multiply by 1.61 .

To convert from tons to kilograms, multiply by 907.18 .

$\mathrm{b}$ VMT $=$ vehicle miles traveled.

of AP-42 and depends on the silt and moisture content of materials being handled. The average values for overburden silt and moisture content given in Section 11.9 of AP-42 are 6.9\% and $7.9 \%$, respectively. For exposed topsoil, the average values for silt and moisture content are given as $15 \%$ and $3.4 \%$, respectively, in Section 13.2.4 of AP-42. Because excavation includes both topsoil and subsurface material, the overall average of $11 \%$ and $5.7 \%$ for silt and moisture contents were used for these calculations.

\section{A.1.2.2 Grading}

Periodic grading was conducted to level the general area during excavations. The predictive emission factor for grading was taken from Section 11.9 of AP-42. The only variable for this factor is the mean grader speed, for which a value of $11.4 \mathrm{~km} / \mathrm{h}(7.1 \mathrm{mph})$ was assumed for this analysis.

\section{A.1.2.3 Unpaved Road Traffic}

It was assumed that the vehicle used to transport the contaminated soil from the site would travel over an unpaved area at the NIF Construction Area. The predictive equation for travel on an unpaved work area was taken from Section 13.2.2 of AP-42. The emissions from this activity are affected by silt content of road aggregate, the characteristics of the vehicle (such as speed, weight, number of wheels), and the number of dry days per year. For this analysis, a silt content of $11 \%$ as determined above was used. Equipment specifications for a 
Ford 10/12 $\mathrm{yd}^{3}$ dump truck were used (Nowinski 1993). A 10-wheel truck with an average weight of 18 metric tons (20 short tons) was assumed to be operated at a speed of $16 \mathrm{~km} / \mathrm{h}$ (10 mph). The number of days with at least $0.25 \mathrm{~mm}(0.01 \mathrm{in}$.) of precipitation was conservatively assumed to be 0 .

\section{A.1.2.4 Dumping}

Dumping activities during cleanup activities included loading contaminated soils onto a truckbed for transport. The predictive factor used for aggregate handling and storage piles was taken from Section 11.2.4 of AP-42. The moisture content of the material transferred and the average wind speed would affect these emissions. Assumptions made for the analysis included a silt content of $11 \%$ as determined above and a wind speed of $7.9 \mathrm{~m} / \mathrm{s}(17.7 \mathrm{mph})$, which was the highest wind speed recorded at LLNL in September 1994 (LLNL 1995).

Emissions from an uncovered truckbed while the truck was being operated were not considered because the truck would be operating at a low speed. Wind erosion from the exposed work area was not considered, under the assumption that contaminated soils being excavated would be shipped off-site as they were excavated, i.e., no stockpiles were maintained.

To estimate total $\mathrm{PM}_{10}$ emissions, the emission factors derived above were multiplied by the activity rates. For excavation, an excavator was operated full time, so the total time of operation was 40 hours over 5 actual working days. For leveling operations during cleanup operations, a tractor was operated part-time, so the total time of operation was assumed to be 20 hours over 5 actual working days. It was conservatively assumed that each hour the tractor made 10 round-trips of a distance equivalent to the longer side of the work area. The truck was assumed to travel into (for loading) and out of (for transporting) the work area. Similarly, the truck was assumed to travel one round-trip of the longer side of the work area per truckload. For dumping, 694 metric tons (766 short tons) of the PCB-contaminated soils were handled. Estimated uncontrolled $\mathrm{PM}_{10}$ emissions resulting from the handling of PCB-contaminated soils under these conditions are summarized in Table A.1.

\section{A.1.3 Air Dispersion Modeling Results}

To assess potential impacts from cleanup activities at the NIF site, the PCB-contaminated $\mathrm{PM}_{10}$ emission estimates were used in air dispersion modeling to determine the $\mathrm{PM}_{10}$ concentration in air at the nearest site boundary and the potential health-related impacts of those emissions. Screening-level air dispersion modeling was first used. This modeling involved simplified calculations incorporating sufficient conservatism to determine if a source of pollutants posed a potential health threat. If the screening-level modeling were to indicate a possible health threat, then more refined modeling would be warranted. 
The SCREEN3 model was used to conduct the conservative screening analysis consistent with EPA's guideline on air quality models (EPA 1995b-c). The "rural" dispersion option was selected, and source and receptor heights were assumed to be at ground level. The receptor location was placed at the closest site boundary (about $400 \mathrm{~m}[1,300 \mathrm{ft}]$ east of the NIF construction site) that might be accessible to the public. The maximum 1-hour $\mathrm{PM}_{10}$ concentration level was predicted by modeling to be $255 \mu \mathrm{g} / \mathrm{m}^{3}$ under neutral atmospheric stability conditions (class D), a wind speed of $1 \mathrm{~m} / \mathrm{s}(2.2 \mathrm{mph}$ ) (likely to be the worst meteorological conditions during daytime working hours) and steady wind direction. Conservatively assuming $\mathrm{PM}_{10}$ emissions from the cleanup activities were sustained at maximum computed values for an 8-hour work period with the specified meteorological conditions (class D and unvarying winds at $1 \mathrm{~m} / \mathrm{s}$ ) maintained during this period, then the maximum 24-hour $\mathrm{PM}_{10}$ concentration would be $85 \mu \mathrm{g} / \mathrm{m}^{3}([8 \times 255] / 24)$. However, actual expected $\mathrm{PM}_{10}$ concentrations at the closest site boundary would be much lower because meteorological conditions, such as wind direction and speed and atmospheric stability, would only favor maximum exposures there a fraction of the time.

\section{A.2 ESTIMATES OF PM 10 EMISSIONS AND DISPERSION FROM THE EAST TRAFFIC CIRCLE AREA EXCAVATION}

Discovery and cleanup activities for PCB-contaminated soils discovered at the ETC Area took place from October 1998 through July 1999. The evaluation of air quality impacts associated with those cleanup activities involved primarily analysis of exposures to airborne contaminants generated during excavation and handling of such wastes. The major concern is human health risk posed by PCB-contaminated soils, and, accordingly, $\mathrm{PM}_{10}$ emissions from contaminated soil handling activities were evaluated. $\mathrm{PM}_{10}$ emissions were estimated and then air dispersion modeling was performed to estimate 24-hour maximum concentrations at the closest site boundary. Other miscellaneous $\mathrm{PM}_{10}$ sources not directly related to contaminated soils were not considered. Descriptions of cleanup activities and meteorological conditions were not provided in detail, so conservative assumptions were made wherever possible. The cleanup activities of PCB-contaminated soil are briefly described as follows:

- In October 1998, excavated PCB-contaminated soil was removed from the ETC Area and transported to the M\&O staging area next to Building B639. This soil was staged in the two southernmost soil storage bins on the western side of the M\&O soil storage area. The soil was placed on and covered with plastic. However, detailed information for these activities is not available, so it is assumed that the same levels of activities that occurred in January 1999 would take place.

- About $230 \mathrm{~m}^{3}\left(300 \mathrm{yd}^{3}\right)$ of stockpiled soil was removed from the $\mathrm{M} \& \mathrm{O}$ staging area and transported to an off-site hazardous waste disposal facility, Envirosafe, Inc., at Grandview, Idaho, over the period of January 6-8, 1999. For this activity, heavy equipment with front-end loader and backhoe was 
used to load the soil on trucks. A total of 15 truckloads of soil were shipped off-site, and cleanup activities were conducted in the morning hours. On January 20,1999, on the basis of the results of soil sampling analysis, about $7.7 \mathrm{~m}^{3}\left(10 \mathrm{yd}^{3}\right)$ more of surface soil was removed and placed in a $14-\mathrm{m}^{3}$ $\left(20-\mathrm{yd}^{3}\right)$ roll-off bin, which was subsequently transported to the same off-site facility.

- On May 5, 1999, the area at the ETC Area was scraped, and about $27 \mathrm{~m}^{3}$ $\left(35 \mathrm{yd}^{3}\right)$ more soil was collected for off-site disposal at the same Idaho facility. A small front-end loader and scraper with a backhoe attachment was used for this activity. Results of subsequent sampling indicated that a smaller area defined by two sampling locations remained where additional soil had to be removed to achieve the CERCLA RPMs' agreed upon action level of $18 \mathrm{ppm}$. On June 7, 1999, an additional $46 \mathrm{~m}^{3}\left(60 \mathrm{yd}^{3}\right)$ of soil was scraped from the affected area, and the exposed surface was resampled for PCBs. One location remained above the PRG. On July 8, 1999, an additional $12 \mathrm{~m}^{3}$ $\left(15 \mathrm{yd}^{3}\right)$ of soil was removed from the final location and resampled for PCBs. Analytical results indicated that the PCB concentration at the remaining location was below the action level of $18 \mathrm{ppm}$.

The air quality analysis described here is based on reports of these activities through July 1999.

\section{A.2.1 Assumptions}

For modeling purposes, the work area where cleanup activities took place was assumed to be a square area of $30 \mathrm{~m}$ by $30 \mathrm{~m}(100 \mathrm{ft}$ by $100 \mathrm{ft}$ ) around the contaminated area or stockpiled area. Cleanup activities are assumed to take place during the daytime hours only (e.g., 8:30 a.m.-12:30 p.m.). A bulldozer was conservatively assumed to represent an excavator (e.g., backhoe) and a scraper. In fact, $\mathrm{PM}_{10}$ emissions from an excavator (e.g., backhoe) are lower than those from a bulldozer, because an excavator stays at one location, excavates the soil and dumps it onto the receiving surface over some period of time, and then moves to the next location. Scraping using a front-end loader/scraper at the ETC Area was assumed to be represented by bulldozing because this activity is different from tractor-scraper activity.

\section{A.2.2 PM $_{10}$ Emission Estimates}

Emission factors used to develop the $\mathrm{PM}_{10}$ emission rates were estimated from a standard reference source (EPA 1995a, hereinafter referred to as AP-42). The emission factors estimated for the various activities are the same as those presented in Table A.1. The parameters used to estimate uncontrolled emission factors for specific activities are described below. 


\section{A.2.2.1 Bulldozing}

The calculations for backhoe and surface scraping operations used the predictive equation for bulldozing operation contained in Section 11.9 of AP-42; that equation is dependent on the silt and moisture content of materials being handled. The average values for overburden silt and moisture content given in Section 11.9 of AP-42 are $6.9 \%$ and $7.9 \%$, respectively. For exposed topsoil, the average values for silt and moisture content are given in Section 13.2.4 of AP-42 as $15 \%$ and $3.4 \%$, respectively. Because excavation includes both topsoil and subsurface material, the overall average of $11 \%$ and $5.7 \%$ for silt and moisture contents were used for these calculations.

\section{A.2.2.2 Unpaved Road Traffic}

The predictive equation for vehicular traffic (haul trucks and front-end loader) on the contaminated work area was taken from Section 13.2.2 of AP-42. This factor is affected by silt content of road aggregate, the characteristics of the vehicle (speed, weight, number of wheels), and the number of dry days per year. For the analysis, a silt content of $11 \%$ as determined above was used. For haul trucks, equipment specification data for the Mack MR600S dump truck were used. A 10-wheel truck with an average weight of 20.3 tons is assumed to be operated at a speed of $10 \mathrm{mph}(16 \mathrm{~km} / \mathrm{h})$. A 4-wheel front-end loader weighing 6.9 tons is assumed to be operated at a speed of $5 \mathrm{mph}(8 \mathrm{~km} / \mathrm{h})$. The number of days with at least $0.25 \mathrm{~mm}(0.01 \mathrm{in}$.) of precipitation per year was conservatively assumed to be 0 .

\section{A.2.2.3 Dumping}

Dumping includes loading contaminated soils onto a truckbed for transport or into storage bins. The predictive factor used for aggregate handling and storage piles was taken from Section 11.2.4 of AP-42. The moisture content of the material being transferred and the average wind speed affects these emissions. For the analysis, a silt content of $11 \%$ as determined above was assumed, and the highest wind speed of $9.4 \mathrm{~m} / \mathrm{s}(21 \mathrm{mph})$ recorded at LLNL in 1994 (Govenia 1995) was used.

Emissions of dust from a truckbed while the truck is in operation were not considered because the truck would be traveling at a low speed for on-site transport, and the load would be covered with a tarp for off-site shipping. Wind erosion from the exposed work area was assumed to be negligible because the pile of waste was covered with plastic each evening.

To estimate total $\mathrm{PM}_{10}$ emissions, the emission factors derived above were multiplied by the activity rates. A front-end loader and backhoe was assumed to operate 2 hours/day for the period January 6-8, 1999 (a total of 12 hours), and 1 hour on January 22, 1999. The same levels of activities as those on January 6-8, 1999, were assumed for work in October 1998. On May 5, 
1999, a small front-end loader and scraper were used for 2 hours each (a total of 4 hours) to remove soils. Conservatively, the truck was assumed to come into (for loading) and out of (for transporting) the contaminated work area and move around the work area for the best location. It was conservatively assumed that the truck traveled one round-trip of the side of the work area per truckload of soil. For dumping, a maximum of about $237 \mathrm{~m}^{3}\left(310 \mathrm{yd}^{3}\right)$ of the PCBcontaminated soils at the $\mathrm{M} \& \mathrm{O}$ staging area was handled. Although water was sprayed to keep the dust to the minimum at the work area, for these calculations it was conservatively assumed that no dust control measures were used. Estimated uncontrolled $\mathrm{PM}_{10}$ emissions resulting from the handling of PCB-contaminated soils associated with the ETC operations are summarized in Table A.2.

\section{A.2.3 Air Dispersion Modeling Results}

To assess potential impacts from cleanup activities of PCB-contaminated soils originating from the ETC Area, air dispersion modeling was performed using the $\mathrm{PM}_{10}$ emissions values estimated above. First, screening-level air dispersion modeling was used, which involves simplified calculations designed with sufficient conservatism to determine if a source of pollutants poses a potential health threat. If the screening-level modeling had indicated that the emissions posed any health threat, then a refined modeling would have been warranted.

The SCREEN3 model recommended by EPA (EPA 1995b) was used for screening purposes. The "rural" dispersion option was conservatively selected, and source and receptor heights were assumed to be at ground level. The receptor location was placed at the closest site boundary (about $100 \mathrm{~m}$ [330 ft] and $400 \mathrm{~m}$ [1,300 ft] due east of the M\&O staging area and the ETC, respectively) that might be accessible to the general public. For activities at the M\&O staging area, the maximum 1 -hour $\mathrm{PM}_{10}$ concentration level was predicted to be $1,990 \mu \mathrm{g} / \mathrm{m}^{3}$ for neutral atmospheric stability (Class D) and a wind speed of $1 \mathrm{~m} / \mathrm{s}$, which are likely to be the worst meteorological conditions during daytime working hours. If this level of $\mathrm{PM}_{10}$ concentration was assumed to be maintained for 4 working hours, then the maximum 24-hour $\mathrm{PM}_{10}$ concentration would be $332 \mu \mathrm{g} / \mathrm{m}^{3}$. However, actual $\mathrm{PM}_{10}$ concentrations at the closest site boundary would be much lower because meteorological conditions, such as wind direction and speed and atmospheric stability, are continuously changing. On the other hand, concentration levels from activities at the ETC — predicted at a 1-hour average of $243 \mu \mathrm{g} / \mathrm{m}^{3}$ and 24-average of $40 \mu \mathrm{g} / \mathrm{m}^{3}$ - are an order of magnitude lower than those at the M\&O staging area. Therefore, estimated impacts from activities in the $\mathrm{M} \& \mathrm{O}$ area alone would sufficiently represent the entire action in this screening level analysis.

\section{A.3 HEALTH RISK ESTIMATES}

Cancer and noncancer risk estimates were determined for both actions by using conventional calculation practice as recommended by the EPA (1989). Only a single 
TABLE A.2 Estimated Total PM10 Emissions from PCB-Contaminated Soils Associated with Cleanup Activities at the East Traffic Circle Area ${ }^{a}$

\begin{tabular}{|c|c|c|c|c|}
\hline \multirow[b]{2}{*}{ Activity } & \multirow{2}{*}{$\begin{array}{c}\text { Uncontrolled } \\
\text { Emission Factor }\end{array}$} & \multirow[b]{2}{*}{ Activity } & \multicolumn{2}{|c|}{ Uncontrolled Emissions } \\
\hline & & & (lb) & $(\mathrm{lb} / \mathrm{h})$ \\
\hline \multicolumn{5}{|c|}{ From ETC Area to M\&O Staging Area } \\
\hline Backhoe & $2.41 \mathrm{lb} / \mathrm{h}$ & $6 \mathrm{~h}$ & 14.4 & 1.2 \\
\hline Front-end loader & $0.58 \mathrm{lb} / \mathrm{VMT}^{\mathrm{b}}$ & $30 \mathrm{mi}$ & 17.4 & 1.5 \\
\hline Truck traffic & $3.92 \mathrm{lb} / \mathrm{VMT}$ & $0.6 \mathrm{mi}$ & 2.2 & 0.19 \\
\hline Dumping & $0.0017 \mathrm{lb} / \mathrm{ton}$ & 642 tons & 1.1 & 0.09 \\
\hline Total & & & 35.1 & 2.9 \\
\hline \multicolumn{5}{|c|}{ From $M \& O$ Staging Area to Off-Site Facility } \\
\hline Backhoe & $2.41 \mathrm{lb} / \mathrm{h}$ & $7 \mathrm{~h}$ & 16.8 & 1.2 \\
\hline Front-end loader & $0.58 \mathrm{lb} / \mathrm{VMT}^{\mathrm{b}}$ & $35 \mathrm{mi}$ & 20.2 & 1.4 \\
\hline Truck traffic & $3.92 \mathrm{lb} / \mathrm{VMT}$ & $0.6 \mathrm{mi}$ & 2.4 & 0.2 \\
\hline Dumping & $0.0017 \mathrm{lb} / \mathrm{ton}$ & 332 tons & 0.6 & 0.05 \\
\hline Total & & & 40.0 & 2.9 \\
\hline \multicolumn{5}{|c|}{ From ETC Area to Off-Site Facility } \\
\hline Scraper & $2.41 \mathrm{lb} / \mathrm{h}$ & $2 \mathrm{~h}$ & 4.8 & 1.2 \\
\hline Front-end loader & $0.58 \mathrm{lb} / \mathrm{VMT}^{\mathrm{b}}$ & $10 \mathrm{mi}$ & 5.8 & 1.4 \\
\hline Truck traffic & $3.92 \mathrm{lb} / \mathrm{VMT}$ & $0.1 \mathrm{mi}$ & 0.3 & 0.1 \\
\hline Dumping & $0.0017 \mathrm{lb} / \mathrm{ton}$ & 37 tons & 0.1 & 0.01 \\
\hline Total & & & 11.0 & 2.7 \\
\hline
\end{tabular}

a Conversions:

To convert from pounds to kilograms, multiply by 0.45 .

To convert from miles to kilometers, multiply by 1.61 .

To convert from tons to kilograms, multiply by 907.18 .

b $\mathrm{VMT}=$ vehicle miles traveled. 
contaminant of concern - PCBs - is identified for the analyses. Similarly, only a single exposure pathway is relevant - inhalation of contaminated dusts $\left(\mathrm{PM}_{10}\right)$. The exposure scenarios assumed that an adult member of the public was standing at the nearest point of public access to the excavation, the fence line due east. The LLNL is an industrial site, and visits of children to the vicinity of the Stipulated Areas would be few and of short duration. Areas outside the fenceline to the east are open fields; any children entering them or riding bikes along the roadway would do so only for brief periods of time. No schools or other institutions are located near the fenceline where children stay or homes where children live. This hypothetical receptor was assumed to stand outdoors at this location for the entire duration of the action and inhale the 1-hour maximum $\mathrm{PM}_{10}$ concentration. The concentration of PCBs on the $\mathrm{PM}_{10}$ was assumed to be the maximum detected in soil samples. This value was converted to a PCB concentration in air via the $\mathrm{PM}_{10}$ concentration. The intake of contaminant $i$ by the receptor, $I_{i}$, was then computed using the following equation:

$$
I_{i}=\frac{C_{i} \times I R \times E T \times E F \times E D}{B W \times A T}
$$

where

$$
\begin{aligned}
C_{i} & =\text { air concentration of contaminant } i\left(\mathrm{mg} / \mathrm{m}^{3}\right) \\
I R & =\text { inhalation rate }\left(\mathrm{m}^{3} / \mathrm{h}\right) \\
E T & =\text { exposure time }(\mathrm{h} / \mathrm{d}) \\
E F & =\text { exposure frequency }(\mathrm{d} / \mathrm{yr}) \\
E D & =\text { exposure duration }(\mathrm{yr}) \\
B W & =\text { body weight }(\mathrm{kg}) ; \text { and } \\
A T & =\text { averaging time }(\mathrm{d})
\end{aligned}
$$

Table A.3 presents the values used in this equation, computed intakes, and computed cancer risks and noncancer impacts for the two actions evaluated. To calculate excess cancer risk, the computed intake is multiplied by the cancer toxicity value (slope factor) for PCBs (2.0 kg-day/mg, EPA IRIS, June 1, 1997). The slope factor used represents an upper bound value and applies to environmental exposures, including those from inhalation of dusts. A standard 70-year exposure averaging time was used to put the cancer risk estimate on the same exposure time basis as the slope factor. Cancer risks estimates for shorter exposures are proportionately smaller. 
TABLE A.3 Intake Parameters, Computed Intakes, and Computed Excess Cancer Risks and Noncancer Impacts for Hypothetical Exposures to Airborne PCBs from Recent Remedial Actions at the NIF Construction Area and East Traffic Circle Area

\begin{tabular}{|c|c|c|}
\hline Input/Result & $\begin{array}{c}\text { NIF Capacitor } \\
\text { Excavation }\end{array}$ & $\begin{array}{c}\text { ETC PCB Soil } \\
\text { Excavation }\end{array}$ \\
\hline Distance to fence line & $400 \mathrm{~m}$ & $100 \mathrm{~m}$ \\
\hline $\mathrm{PM}_{10}$ 1-h max. & $255 \mu \mathrm{g} / \mathrm{m}^{3}$ & $1,990 \mu \mathrm{g} / \mathrm{m}^{3}$ \\
\hline PCB conc. on dust & $66 \mu \mathrm{g} / \mathrm{g}$ & $133 \mu \mathrm{g} / \mathrm{g}$ \\
\hline PCB conc. in air, 1-h $\max \left(C_{i}\right)$ & $0.017 \mu \mathrm{g} / \mathrm{m}^{3}$ & $0.26 \mu \mathrm{g} / \mathrm{m}^{3}$ \\
\hline Inhalation rate (IR) & $0.83 \mathrm{~m}^{3} / \mathrm{h}$ & $0.83 \mathrm{~m}^{3} / \mathrm{h}$ \\
\hline Exposure time $(\mathrm{ET})$ & 8 h/day & 4 h/day \\
\hline Exposure frequency (EF) & $10 \mathrm{day} / \mathrm{yr}$ & 4 day/yr \\
\hline Exposure duration (ED) & $1 \mathrm{yr}$ & $1 \mathrm{yr}$ \\
\hline Body weight (BW) & $70 \mathrm{~kg}$ & $70 \mathrm{~kg}$ \\
\hline Averaging time (AT), cancer & 25,550 days $(70 \mathrm{yr})$ & 25,550 days $(70 \mathrm{yr})$ \\
\hline Averaging time, non-cancer & 10 days & 4 days \\
\hline Intake, cancer $\left(\mathrm{I}_{\mathrm{c}}\right)$ & $6.2 \times 10^{-10} \mathrm{mg} / \mathrm{kg}$-day & $2.0 \times 10^{-9} \mathrm{mg} / \mathrm{kg}$-day \\
\hline Slope factor (SF) & $2 \mathrm{~kg}$-day $/ \mathrm{mg}$ & $2 \mathrm{~kg}$-day $/ \mathrm{mg}$ \\
\hline Excess cancer risk $\left(\mathrm{SF} \times \mathrm{I}_{\mathrm{c}}\right)$ & $1 \times 10^{-9}$ & $4 \times 10^{-9}$ \\
\hline Intake, non-cancer $\left(\mathrm{I}_{\mathrm{nc}}\right)$ & $1.6 \times 10^{-6} \mathrm{mg} / \mathrm{kg}$-day & $1.25 \times 10^{-5} \mathrm{mg} / \mathrm{kg}$-day \\
\hline Reference dose (RfD) & $2 \times 10^{-5} \mathrm{mg} / \mathrm{kg}$-day & $2 \times 10^{-5} \mathrm{mg} / \mathrm{kg}$-day \\
\hline Hazard quotient $\left(\mathrm{I}_{\mathrm{nc}} \div \mathrm{RfD}\right)$ & 0.08 & 0.6 \\
\hline
\end{tabular}

Estimated excess cancer risks to a hypothetical receptor were $1 \times 10^{-9}$ and $4 \times 10^{-9}$ for the NIF and ETC area excavations, respectively. These values are well below the point of departure for determining remediation goals of $1 \times 10^{-6}$ (40 CFR 300, National Oil and Hazardous Substances Pollution Contingency Plan, Final Rule, March 8, 1990).

Computation of intakes for noncancer risks also used Equation A.1, except an averaging time equal to the exposure period (10 or 4 days) was used. Such an exposure period is consistent with acute exposures, but in this analysis the more sensitive toxicity value for chronic exposure was used. The conservatively computed intake was then compared to a reference dose that represents a safe level for chronic exposure $\left(2.0 \times 10^{-5} \mathrm{mg} / \mathrm{kg}\right.$-day [AR1254, EPA IRIS, March 1, 1997]). This reference dose was developed by using oral exposures. No inhalation reference dose value was available in IRIS. However, except for a number of metals and certain other contaminants, it is generally acceptable to extrapolate an oral toxicity value to inhalation exposures, particularly for screening purposes.

The computed hazard quotients of 0.08 for the NIF capacitor excavation and 0.6 for the ETC excavation in this case indicates exposures that are below the threshold level of 1.0 
considered safe for even chronic exposures (EPA [1997] IRIS). As with cancer risks, then, noncancer risks can be considered below levels of concern. The results for these conservative screening-level analyses eliminate the need for more detailed analysis of health risks.

\section{A.4 REFERENCES FOR APPENDIX A}

Bainer, R.W., and L.L. Berg (eds.), 1998, Action Memorandum for an Emergency Removal Action at the National Ignition Facility Construction Site, UCRL-AR-128728, U.S. Department of Energy, Oakland Operations Office, Oakland, Calif., and Lawrence Livermore National Laboratory, Livermore, Calif., Feb.

Govenia, F., 1995, unpublished meteorological data for 1994, transmittal from Govenia (Lawrence Livermore National Laboratory, Livermore, Calif.) to A. Policastro (Argonne National Laboratory, Argonne, Ill.), July.

Lawrence Livermore National Laboratory, 1995, unpublished meteorological data for 1994, transmittal from F. Govenia (Lawrence Livermore National Laboratory, Livermore, Calif.) to A. Policastro (Argonne National Laboratory, Argonne, Ill.), July.

Nowinski, R., 1993, facsimile transmittal from R. Nowinski (John Ford's Freeway Ford Truck Sales, Inc., Lyons, Ill.) to K.C. Chun (Argonne National Laboratory, Argonne, Ill.), Aug. 20.

U.S. Environmental Protection Agency, 1989, Risk Assessment Guidance for Superfund, Volume 1, Human Health Evaluation Manual, EPA/540/1-89/002, Office of Emergency and Remedial Response, Washington, D.C.

U.S. Environmental Protection Agency, 1995a, Compilation of Air Pollutant Emission Factors, AP-42, 5th ed., Office of Air Quality Planning Standards, Research Triangle Park, N.C., Jan.

U.S. Environmental Protection Agency, 1995b, SCREEN3 Model User's Guide, EPA-454/B-95004, Office of Air Quality Planning Standards, Research Triangle Park, N.C., Sept.

U.S. Environmental Protection Agency, 1995c, Supplement C to the Guideline on Air Quality Models (Revised), EPA-450/20670926R-C, Office of Air Quality Planning Standards, Research Triangle Park, N.C., Aug.

U.S. Environmental Protection Agency, 1997, Integrated Risk Information System (IRIS), Washington, D.C. 


\section{APPENDIX B:}

MODELING GROUNDWATER IMPACTS FROM THE PCB CAPACITOR LANDFILL 
B-2

[This page intentionally left blank.] 


\section{APPENDIX B:}

\section{MODELING GROUNDWATER IMPACTS FROM THE PCB CAPACITOR LANDFILL}

\section{B.1 INTRODUCTION}

As discussed in the Action Memorandum (Bainer and Berg 1998), 112 capacitors containing polychlorinated biphenyls (PCBs) were unearthed at the NIF construction site located in the northeastern portion of the Livermore Site (Figures B.1 and B.2). The capacitors and about 694 metric tons (766 short tons) of PCB-contaminated soils were removed. An excavated trench about $6.1 \mathrm{~m}(20 \mathrm{ft})$ wide, $21 \mathrm{~m}(70 \mathrm{ft})$ long and $5.2 \mathrm{~m}(17 \mathrm{ft})$ deep was used for this removal operation. The highest concentration of PCBs in the removed soils was $66 \mathrm{ppm}$. After removal, residual PCB levels were less than $1 \mathrm{ppm}$, consistent with environmental regulations and cleanup levels established in coordination with the CERCLA Remedial Project Managers (RPMs), who represent the U.S. Environmental Protection Agency (EPA), the California Department of Toxic Substances Control, and the San Francisco Bay Region Water Quality Board. The purpose of this appendix is to estimate the effects of PCBs on groundwater beneath the extraction trench.

\section{B.2 PHYSICAL PROPERTIES OF PCBs}

To perform any analyses for the extraction trench, physical and chemical properties of the capacitor material is needed. As mentioned in the Action Memorandum (Bainer and Berg 1998), the material in the capacitors was identified as Diaclor, although soil analyses from around the capacitors was reported as Aroclor 1254. PCBs were sold under the trade name Aroclor, although companies that used PCBs in the manufacture of capacitors often used other trade names, such as Diaclor. PCBs are produced by the chlorination of biphenyl. One to 10 hydrogen atoms of biphenyl can be replaced with chlorine atoms. Given all of the possible arrangements of chlorine atoms, there are 209 compounds (congeners) that are classified as PCBs (Mackay et al. 1992). These compounds do not readily degrade in groundwater systems.

Commercial mixtures of PCBs were manufactured under the trade name Aroclor. Aroclors 1260, 1254, and 1242 were most frequently used in electrical equipment. Aroclor 1260 contains 60\% by weight chlorine, Aroclor 1254 contains $54 \%$ by weight chlorine, etc. For the purposes of this appendix, the capacitor material will be assumed to have the properties of the Aroclor 1254, and the results of surveys were reported as Aroclor 1254.

For the following calculations, two properties are required. The first is the solubility of the Aroclor in water. The Aroclor with the highest solubility would contribute the most material 


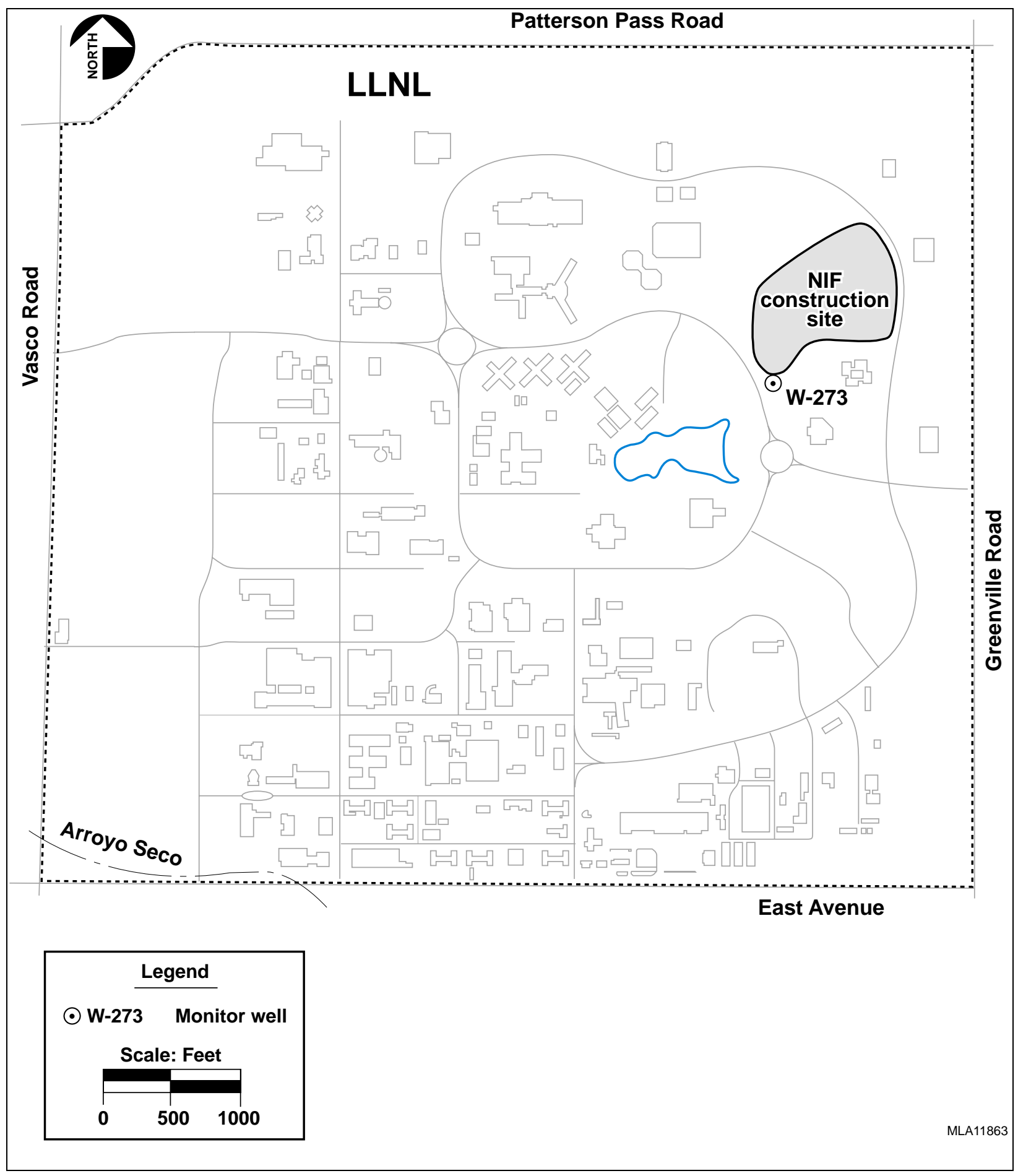

FIGURE B.1 Location of the NIF Construction Site at the LLNL Livermore Site (Source: Bainer and Berg 1998) 


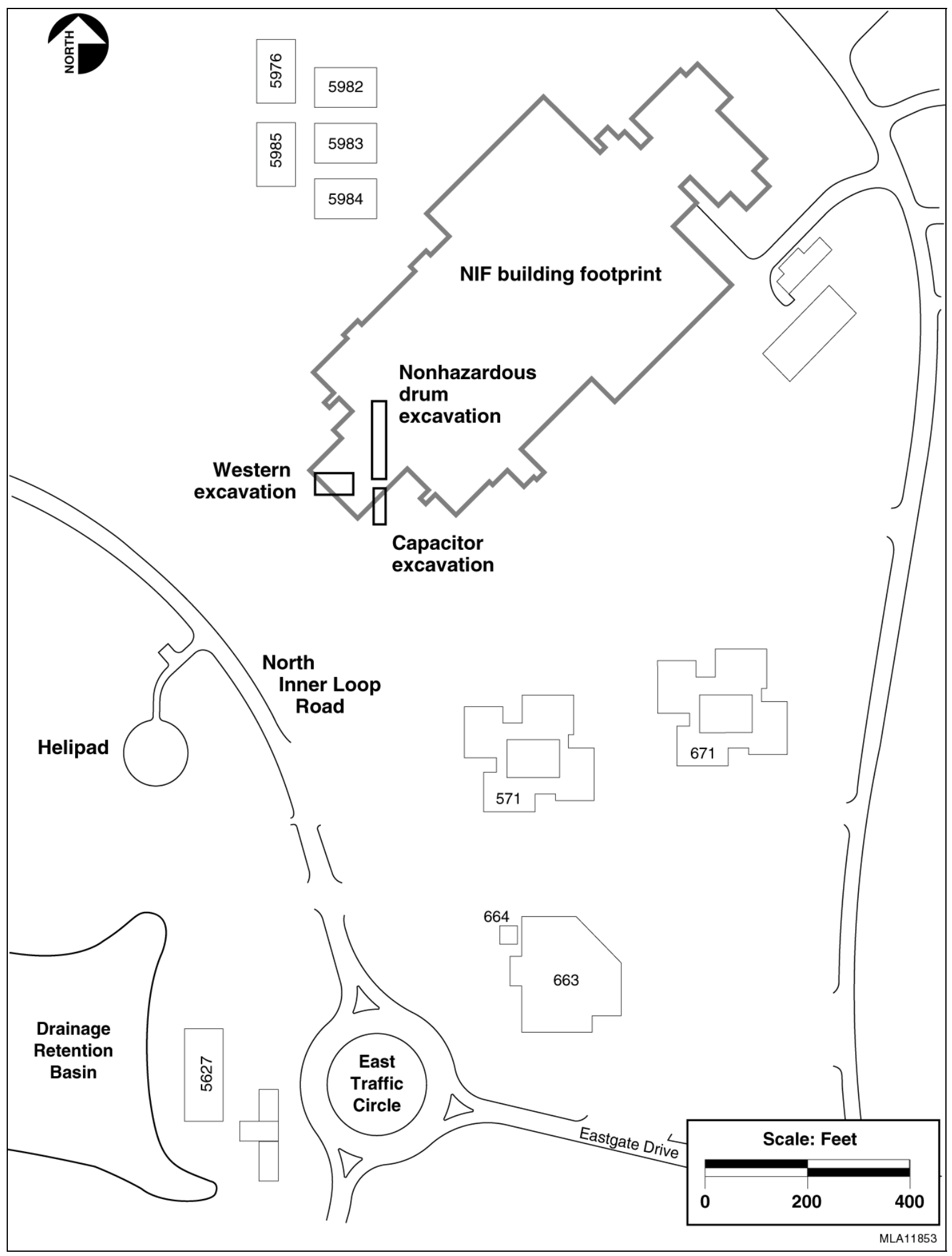

FIGURE B.2 Location of the Capacitor, Drum, and Western Excavations at the NIF Construction Area and Location of the East Traffic Circle Area (Source: Modified from Bainer and Berg 1998) 
to the liquid phase and produce the greatest impact on the groundwater. The second property of interest is the partition coefficient (designated $\mathrm{K}_{\mathrm{d}}$ ) for the Aroclor. The partition coefficient defines the amount of material that would be in equilibrium between the sorbed and aqueous phase. That is, $K_{d}$ is the mass of solute on the solid phase per unit mass of solid phase divided by the concentration of solute in solution (Freeze and Cherry 1979). When appropriately combined with soil properties, the distribution coefficient will provide an indication of how fast, relative to the groundwater velocity, the contaminant will move in the system. The higher the value of $\mathrm{K}_{\mathrm{d}}$, the slower the contaminant will move. Values for $\mathrm{K}_{\mathrm{d}}$ are rarely available; however, a counterpart, $\mathrm{K}_{\mathrm{oc}}$, is available in the literature, where $\mathrm{K}_{\mathrm{oc}}$ is the sorption coefficient normalized for organic carbon. $K_{d}$ can be readily found given $K_{o c}$ by using the following relation:

$$
K_{d}=f_{o c} K_{o c},
$$

where $f_{o c}$ is the fraction of organic material present in the soil. Table B.1 lists the solubilities and $\mathrm{K}_{\mathrm{oc}}$ values from Montgomery and Welkom (1991). Of the potential Aroclors, 1242, with its high solubility and low $\mathrm{K}_{\mathrm{oc}}$, would produce the largest impacts to groundwater, and will, therefore, be used in the subsequent analyses.

\section{B.3 FATE AND TRANSPORT}

In its simplest form, contaminant transport through a porous material can be described by the following one-dimensional partial differential equation (Freeze and Cherry 1979):

$$
\frac{\partial C}{\partial t}=-\frac{V}{R} \frac{\partial C}{\partial Z}+\frac{D}{R} \frac{\partial^{2} C}{\partial Z^{2}}
$$

where:

$$
\begin{aligned}
& C=\text { contaminant concentration at time, } t, \text { depth } Z ; \\
& D=\text { dispersion coefficient; } \\
& R=\begin{array}{r}
\text { retardation coefficient given by the expression } R=1 \rho_{b} K_{d} / \phi, \text { where } \rho_{b} \text { is the } \\
\text { bulk density of the porous material and } \phi \text { is its effective porosity; }
\end{array} \\
& t=\text { time; } \\
& V=\text { actual groundwater velocity; and } \\
& Z=\text { vertical distance. }
\end{aligned}
$$


TABLE B.1 Aroclor Properties

\begin{tabular}{cccr}
\hline & & & \\
Aroclor & Solubility $(\mathrm{mg} / \mathrm{L})$ & $\log \mathrm{K}_{\mathrm{Oc}}$ & $\mathrm{K}_{\mathrm{Oc}}(\mathrm{mL} / \mathrm{g})$ \\
\hline & & & \\
1242 & 0.1 & 3.71 & 5,129 \\
1254 & 0.057 & 5.61 & 407,400 \\
1260 & 0.08 & 6.42 & $2,630,000$ \\
\hline
\end{tabular}

Source: Montgomery and Welkom (1991).

The dispersion coefficient, $D$, in Equation B.2 is assumed to follow the function form given by Bear (1972):

$$
D=\alpha V
$$

where $\alpha$ is the dispersivity of the medium. Diffusional effects are assumed to be negligible relative to advection.

Dispersivity in Equation B.3 is assumed to be scale-dependent (Lallemand-Barres and Peaudecerf 1978); that is:

$$
\alpha=0.1 L
$$

where $L$ is distance from the top of the soil column to the water table.

Use of Equation B.2 makes the following simplifying approximations:

- Lateral transport from the surface to the water table is small (most infiltration occurs vertically),

- The infiltration velocity is constant in time and space, approximate for scoping calculations where the distance between the soil surface and groundwater surface is long,

- The soil is homogeneous,

- The contaminant is conservative (i.e., it does not decay or degrade in any way along its flow path), 
- Sorption processes can be represented with a linear isotherm (i.e., sorption processes are fast and reversible).

If the impacts calculated with the model described by Equation B.2 are large, additional, more detailed calculations would be required in accordance with NEPA guidance.

In order to solve Equation B.2, two boundary conditions are needed. The first assumes that the concentration of the Aroclor goes to zero as the vertical distance goes to infinity. The second boundary condition is applied at the ground surface $(Z=0.0)$. At this location, the Aroclor is assumed to behave as a unit square-wave source in time. That is, the concentration at $Z=0$ is some initial value, $C_{0}$, and remains so until a time equal to $\Delta t$, when the concentration returns to zero. The initial concentration is simply equal to the solubility of Aroclor. This type of boundary can be described by the following equation:

$$
\frac{C}{C_{0}}=U(t-0.0)-U(t-\Delta t),
$$

where $U$ is the unit function (Kreyszig 1967).

Equation B.2, subject to the above boundary conditions, was solved using the method of Laplace transforms. The solution is given by the following expression (Tomasko 1992):

$$
\begin{aligned}
& \frac{C}{C_{0}}=\frac{1}{2}\left(\operatorname{erfc}\left(\frac{Z R-V t}{2 \sqrt{D R t}}\right)+e^{\frac{v z}{d}} \operatorname{erfc}\left(\frac{Z R+V t}{2 \sqrt{D R t}}\right)\right) \\
& -\frac{1}{2} H(t-\Delta t)\left(\operatorname{erfc}\left(\frac{Z R-V(t-\Delta t)}{2 \sqrt{D R(t-\Delta T)}}\right)+e^{\frac{V Z}{D}} \operatorname{erfc}\left(\frac{Z R+V(t-\Delta t)}{2 \sqrt{D R(t-\Delta t)}}\right)\right),
\end{aligned}
$$

where $H$ is the Heaviside function (Hildebrand 1976) such that:

$$
H(t-\Delta t)=0 \text { for } t<\Delta t,
$$

and

$$
\begin{aligned}
& H(t-\Delta t)=1 \text { for } t \geq \Delta t \text {, and } \\
& \qquad \operatorname{erf}(\gamma)=1-\operatorname{erf}(\gamma)=1-\frac{2}{\sqrt{\pi}} \int_{o}^{y} e^{-\lambda^{2}} d \lambda .
\end{aligned}
$$




\section{B.4 POROUS MEDIUM INPUT VALUES}

To solve Equation B.6, a number of physical parameters are required. Many of these were discussed in the main text. The vertical distance from the ground surface to the water table

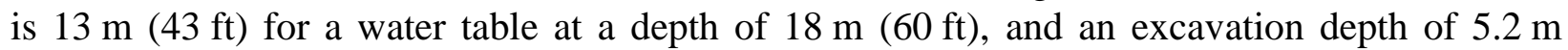
$(17 \mathrm{ft}$ ) for the capacitor trench. Retardation, $\mathrm{R}$, for Aroclor 1242 is about 487 using a fraction of organic carbon in the soil of $1.7 \%$ (Maidment 1992), an average bulk density for the soil of $1.89 \mathrm{~g} / \mathrm{cm}^{3}$, and an average effective porosity of 0.339 derived from soil sample data at the NIF site (Stephens and Associates, Inc. 1996). The vertical groundwater velocity is assumed to be equal to the average annual recharge to HSU $1,33 \mathrm{~mm} / \mathrm{yr}(1.33 \mathrm{in.} / \mathrm{yr}[0.11 \mathrm{ft} / \mathrm{yr}])$ (Vogele et al. 1996). For this velocity and travel distance, the computed dispersion coefficient is $0.04 \mathrm{~m}^{2} / \mathrm{yr}$ $\left(0.47 \mathrm{ft}^{2} / \mathrm{yr}\right)$.

In addition to the above parameters, the duration of the Aroclor 1242 is needed for Equation B.6. This duration can be roughly approximated by assuming that the infiltrating precipitation dissolves the PCB from the soil at a solubility-limited concentration and then transports the solute vertically downwards to the water table. By mass conservation,

$$
\Delta t=\frac{\rho_{1242} t_{h}}{V S o l},
$$

where:

$$
\begin{aligned}
\text { Sol } & =\text { solubility of the Aroclor, } \\
t & =\text { thickness of the residual contamination (about } 0.3 \mathrm{~m}[1 \mathrm{ft}] \text { ), and } \\
\rho_{1242} & =\text { density of Aroclor } 1242 .
\end{aligned}
$$

As specified in the Action Memorandum (Bainer and Berg 1998), the PCBs were cleaned up to a concentration of less than $1 \mathrm{ppm}$. For the soils at the NIF site (Stephens and Associates, Inc. 1996), the average dry density is about $1.75 \mathrm{~g} / \mathrm{cm}^{3}$, and, therefore, the concentration of Aroclor is $1.75 \times 10^{-6} \mathrm{~g} / \mathrm{cm}^{3}$. The duration of residual Aroclor in the soil is thus about 160 years.

\section{B.5 CALCUlations}

Figure B.3 shows the normalized concentration $\left(\mathrm{C} / \mathrm{C}_{0}\right)$ as a function of time (breakthrough curve) calculated with Equation B.6 and as many site-specific parameters as possible. For these conditions, Aroclor 1242 will attain a maximum concentration of about 0.001 after 


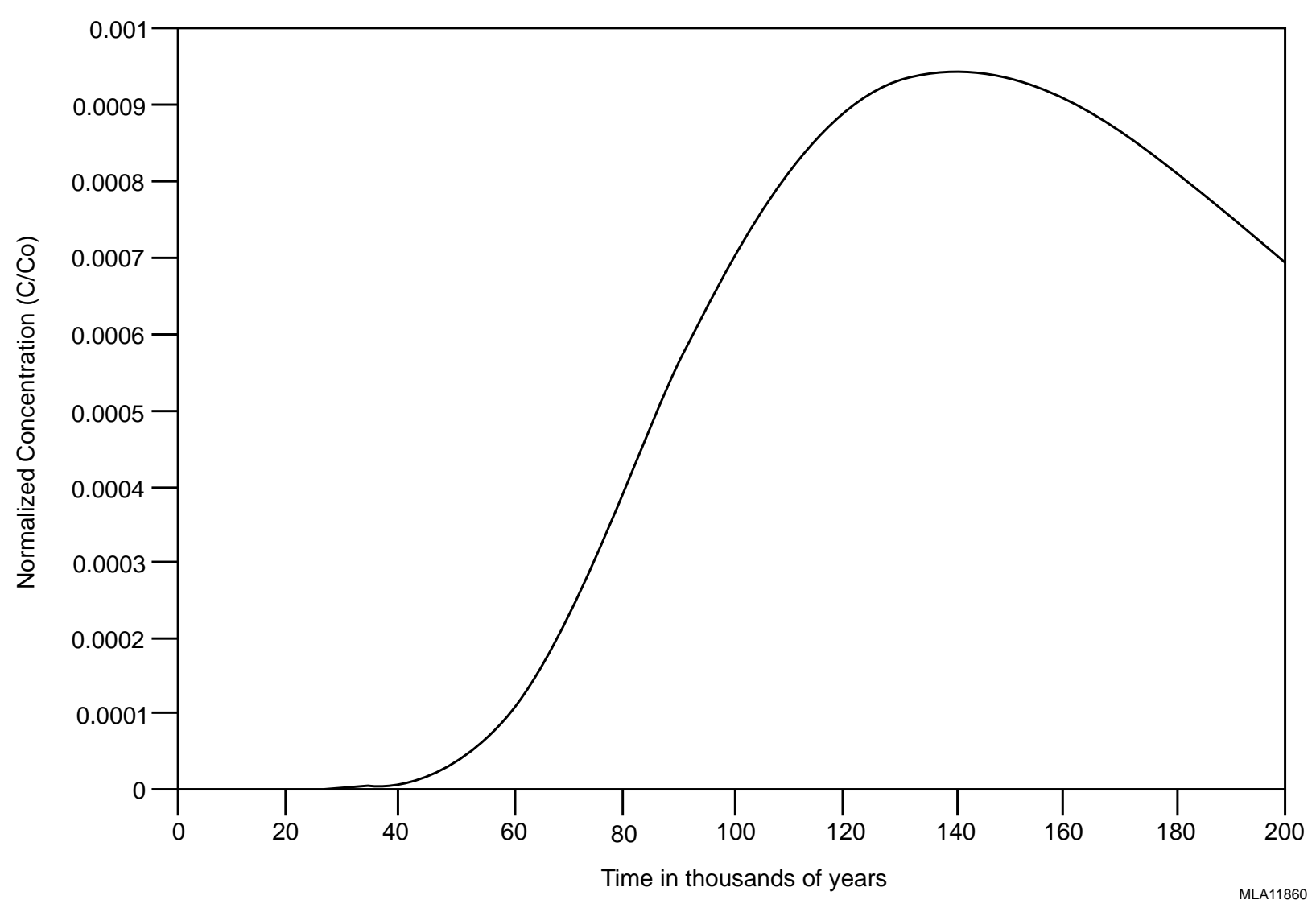

FIGURE B.3 Water Table Breakthrough Curve for PCB (Aroclor 1242) at the NIF Construction Area

approximately 140,000 years. This long breakthrough curve is primarily the result of the high degree of retardation and is not unexpected. To get an actual water concentration at the water table, the value 0.001 must be multiplied by the initial concentration at the ground surface (assumed to be equal to the solubility of Aroclor $1242-1.0 \times 10^{-7} \mathrm{~g} / \mathrm{cm}^{3}$ ). The resulting maximum Aroclor concentration at the water table would, therefore, be about $1.0 \times 10^{-10} \mathrm{~g} / \mathrm{cm}^{3}$. This value is about $20 \%$ of the EPA maximum contaminant level (MCL) for drinking water (EPA 1994).

Once the infiltrating water that contains Aroclor 1242 reaches the water table, mixing will occur. A simple mixing model (Tomasko 1992) was used, as found from the following expression:

$$
d_{f}=\frac{V_{d} t_{h}}{I X_{l} \phi}+1,
$$


where:

$$
\begin{aligned}
I= & \text { infiltration rate, } \\
t_{h}= & \text { thickness of HSU } 1(9 \mathrm{~m}[30 \mathrm{ft}]), \\
V_{d}= & \text { Darcy velocity in HSU } 1 \text { (about } 0.34 \mathrm{~m} / \mathrm{yr}[1.1 \mathrm{ft} / \mathrm{yr}] \text { ), and } \\
X_{l}= & \begin{array}{l}
\text { width of contamination zone parallel to the direction of groundwater flow } \\
\quad \text { (assumed to be equal to the width of the excavation trench }-6 \mathrm{~m}[20 \mathrm{ft}]) .
\end{array}
\end{aligned}
$$

The concentration of Aroclor 1242 in groundwater after mixing would, therefore, be about $2.5 \times 10^{-12} \mathrm{~g} / \mathrm{cm}^{3}(0.0025 \mathrm{ppb})$, which is about $0.5 \%$ of the MCL for drinking water.

\section{B.6 REFERENCES FOR APPENDIX B}

Bainer, R.W., and L.L. Berg (eds.), 1998, Action Memorandum for an Emergency Removal Action at the National Ignition Facility Construction Site, Lawrence Livermore National Laboratory Livermore Site, UCRL-AR-128728, U.S. Department of Energy, Oakland Operations Office, Oakland, Calif., and Lawrence Livermore National Laboratory, Livermore, Calif., Feb.

Bear, J., 1972, Dynamics of Fluids in Porous Media, American Elsevier Publishing Company, New York, N.Y.

Freeze, R.A., and J.A. Cherry, 1979, Groundwater, Prentice-Hall, Inc., Englewood Cliffs, N.J.

Hildebrand, F.B., 1976, Advanced Calculus for Applications, Prentice-Hall, Inc., Englewood Cliffs, N.J.

Kreyszig, E., 1967, Advanced Engineering Mathematics, John Wiley and Sons, Inc., New York, N.Y.

Lallemand-Barres, A., and P. Peaudecerf, 1978, "Recherche des Relations entre la Valeur de la Dispersivite Macroscopique d'un Milieu Aquifere, Ses Autres Caracteristiques et les Conditions de Mesure," Bulletin Bureau Geologique Minieres 4-1978:277-284.

Mackay, D., et al., 1992, Illustrated Handbook of Physical-Chemical Properties and Environmental Fate for Organic Chemicals, Volume 1, Monoaromatic Hydrocarbons, Chlorobenzenes, and PCBs, Lewis Publishers, Inc., Chelsea, Mich. 
Maidment, D.R., 1992, Handbook of Hydrology, McGraw-Hill, Inc., New York, N.Y.

Montgomery, J.H., and L.M. Welkom, 1991, Groundwater Chemicals Desk Reference, Lewis Publishers, Inc., Chelsea, Mich.

Stephens and Associates, Inc., 1996, letter report to Lawrence Livermore National Laboratory, Sept. 16.

Tomasko, D., 1992, Modeling Vertical and Horizontal Solute Transport for the Weldon Spring Site Remedial Action Project, ANL/EAIS/TM-77, Argonne National Laboratory, Argonne, Ill., Nov.

U.S. Environmental Protection Agency, 1994, Drinking Water Regulations and Health Advisories, Office of Water, Washington, D.C.

Vogele, T.J., et al., 1996, Simulation of Soil Vapor Extraction at Building 518 Lawrence Livermore National Laboratory Livermore Site, UCRL-AR-124995, Livermore, Calif., Sept. 
At1-1

ATTACHMENT 1:

JOINT STIPULATION AND ORDER 
At1-2

[This page intentionally left blank.] 


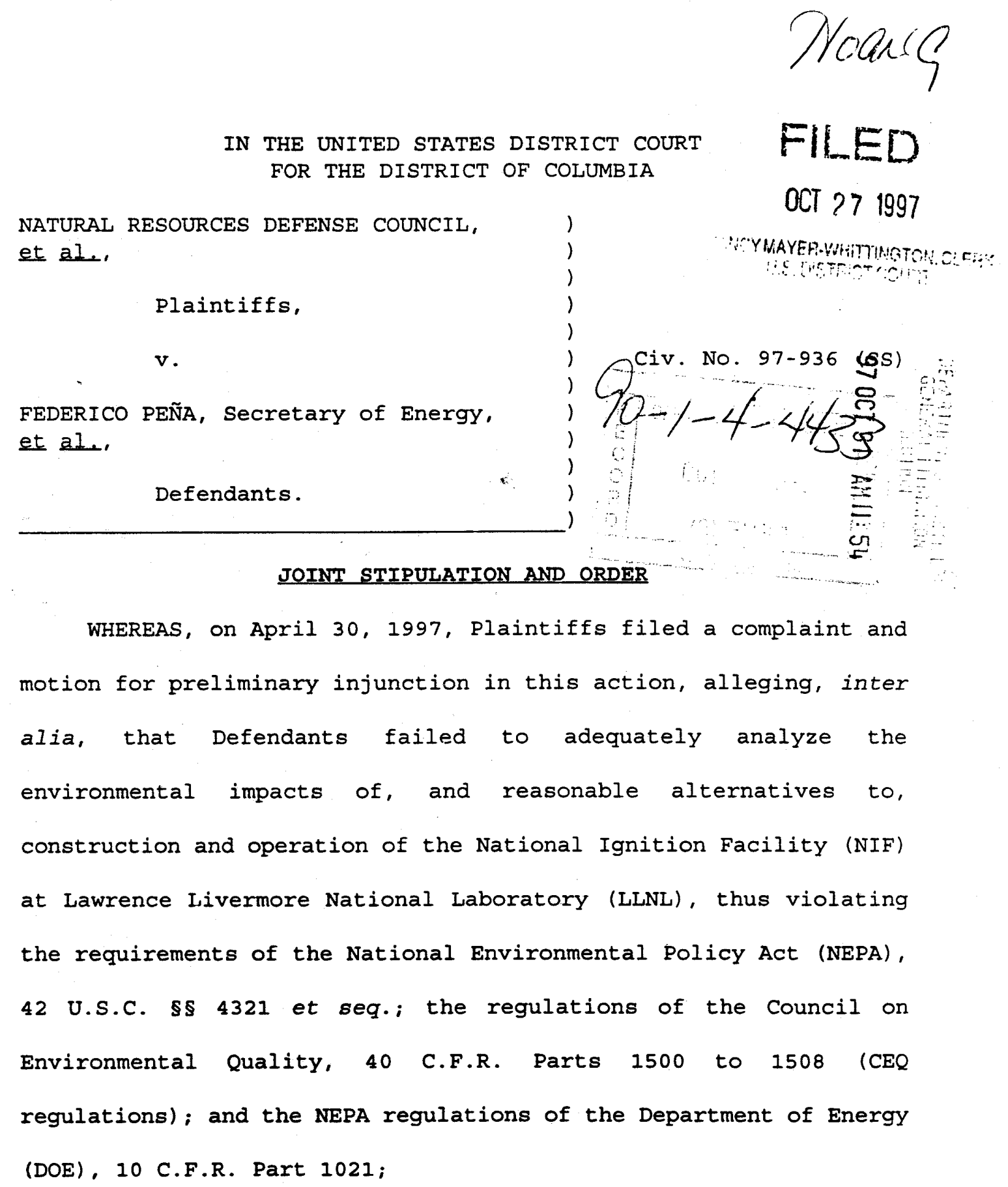

WHEREAS, on August 8,1997 , the Court denied Plaintiffs' motion in part and granted it in part, finding, inter alia, that Defendants had looked carefully at NIF; 
WHEREAS, on September 3-12, 1997, after denial of Plaintiffs' motion for preliminary injunction directed towards construction of NIF, Defendants unearthed, removed from the NIF excavation pit, and disposed of 112 capacitors contaminated with toxic polychlorinated biphenyls (PCB's) and approximately 784 tons of PCB-contaminated soil, as well as 75 corroded waste drums;

WHEREAS, Defendants assert that they conducted the foregoing removal and disposal activities in accordance with applicable laws and regulations and in a manner that did not pose any threat to the public health and safety or to the environment;

WHEREAS, Plaintiffs contest this assertion;

WHEREAS, on September 22, 1997, Plaintiffs moved under Rule $60(b)$ of the Federal Rules of Civil Procedure for relief from that part of the Court's Order of August 8, 1997, denying Plaintiffs' motion for preliminary injunction of construction and excavation of the NIF pending a ruling on the merits of its claims under NEPA, alleging, inter alia, that Defendants previously knew but did not adequately analyze and disclose in the Programmatic Environmental Impact statement for the Stockpile stewardship and Management (SSM) Program (SSM PEIS) the risk of building the NIF in an area that may contain buried hazardous, toxic, and/or radioactive wastes;

WHEREAS, Defendants assert that the analysis in the SSM PEIS 
regarding the environmental impacts of constructing and operating NIF was fully adequate and that the discovery of the hazardous materials at the NIF excavation site constituted new information; WHEREAS, Plaintiffs contest this assertion; WHEREAS, Defendants deny the allegations in Plaintiffs' Rule 60 (b) motion, including the allegation that Defendants previously knew but did not adequately analyze and disclose in the SSM PEIS the risk of building the NIF in an area that may contain buried hazardous, toxic, and/or radioactive wastes;

WHEREAS, upon the Court's request, Plaintiffs filed a detailed proposed order on September 23, 1997, suggesting additional studies and analyses for Defendants to prepare regarding hazardous materials in the area in and around the NIF excavation site;

WHEREAS, on September 24, 1997, Defendants filed a response to Plaintiffs' proposed order of September 23, 1997, asserting, inter alia, that they have conducted, and plan to continue, detailed evaluations at and nearby the NIF construction site;

WHEREAS, Plaintiffs contest Defendants' assertion that their detailed evaluations are adequate;

WHEREAS, entry into this Joint Stipulation and order is made in good faith in an effort to avoid further expensive and protracted litigation, without any admission by Defendants or any 
concurrence by Plaintiffs as to whether Defendants have violated any applicable laws and regulations, including NEPA, the CEQ regulations or the DOE NEPA regulations, and without any admission by Defendants that they are obligated to prepare and circulate, for public review and comment, a supplement to the SSM PEIS, which evaluates the reasonably foreseeable significant adverse environmental impacts of continuing to construct and operating NIF at LLNL in an area that may be contaminated with hazardous, toxic, and/or radioactive substances;

WHEREAS, each undersigned representative of the parties certifies that he or she is fully authorized to enter into and execute this stipulation on behalf of each respective party and to legally bind such party to this stipulation;

NOW THEREFORE, the undersigned attorneys for the respective parties to this action hereby stipulate and agree as follows:

I. As specified in paragraphs 2-6 below, Defendants will conduct a full evaluation of any potential risks to the human environment resulting from continuing to construct and operating the NIF at ILNL in an area that may be contaminated with hazardous, toxic, and/or radioactive substances;

2. Beginning within 10 days of entry of this Joint Stipulation and Order, Defendants will review all available 
reports, studies, maps, aerial photographs and other available records, and interview workers at LLNL who are reasonably known to have relevant knowledge, in order to determine as accurately as possible whether and where hazardous, toxic, and/or radioactive materials may be buried in the following areas, as further identified in the attached map:

a. Helipad Area (Area 1);

b. Building 571 Area (Area 2);

c. Northern Boundary Area (Area 3);

d. Building 490 Area (Area 5);

e. East Traffic Circle Area (unnumbered but marked; buried PCB-laden capacitors and other waste found in an undocumented dump in this area);

f. East Gate Drive Area (Area 15) (another undocumented hazardous waste dump found near this area);

9. The area extending from Areas 1, 2 and 5 to and including the NIF construction site, and beyond to the perimeter of the circular road immediately beyond the NIF construction site, as marked on the map.

3. In the event that the activities conducted under paragraph 2 reveal any areas where hazardous, toxic, and/or radioactive substances may be buried, Defendants will conduct additional surface geophysics analyses as reasonably necessary to obtain relevant information as to potential significant adverse impacts. In conducting such analyses, Defendants will use 
appropriate technologies, in accordance with standard industry practice, such as electrical induction surveys, magnetometers, seismic refraction, and/or ground penetrating radar.

4. In the event that the investigation in paragraph 3 reveals or confirms areas where hazardous, toxic, and/or radioactive materials may be buried, Defendants will conduct whatever further analyses are reasonably necessary to evaluate potential risks, including, at a minimum, soil borings and/or soil vapor studies.

5. Defendants are currently drilling a groundwater monitoring well at the Helipad Area (Area 1), and, based on findings therefrom, they will drill one additional groundwater monitoring well within the next six months. Defendants will drill one or more additional groundwater monitoring wells in the area surrounding the NIF construction site, as reasonably necessary, to evaluate the potential impact of any dewacering activities that may be conducted to remove contaminated groundwater from the NIF construction site.

6. During performance of the above activities, Defendants shall provide Plaintiffs and the Court with a report every 90 days (a) summarizing the progress they have made in conducting the above analyses and in constructing the NIF, and (b) describing the analyses and NIF construction activities (including locations and 
schedules) that are planned for the next 90-day period. Defendants shall file the first report on or before November 27, 1997. Defendants shall meet with Plaintiffs upon issuance of each report, and up to four additional times annually, if requested by Plaintiffs, to discuss these issues further.

7. Following completion of the above activities described in paragraph 2-5 of this Joint Stipulation and Order, Defendants will prepare and circulate for public review and comment in accordance with DOE NEPA regulation 10 C.F.R. \$ $1021.314($ d), a supplement to the SSM PEIS, which evaluates the reasonably foreseeable significant adverse environmental impacts of continuing to construct and of operating NIF at LINL with respect to any potential or confirmed contamination in the area by hazardous, toxic, and/or radioactive materials.

8. Pending completion of the above activities, Defendants will take no action with respect to construction of the National Ignition Facility that may threaten the public health, safety and/or the environment, with respect to the potential migration of hazardous, toxic, and/or radioactive materials or contaminated groundwater.

9. The Court may hold a hearing one year after the signing of this Joint Stipulation and Order to review Defendants' progress in 
complying with its provisions.

10. Pending Defendants' completion of a supplement to the SSM PEIS and the issuance of a Record of Decision based thereon, the Court shall retain jurisdiction over this matter to enforce the terms of this Joint Stipulation and order.

11. Defendants may consult with the United States Environmental Protection Agency, the California Department of Toxic Substances Control, and the California Regional water Quality Control Board (the regulators) about the activities to be taken pursuant to this Joint stipulation and order. Nothing in this Joint Stipulation and Order shall require Defendants to conduct any of the foregoing activities in the event that any of the regulators determines that that activity may be detrimental to public health and safety or the environment. In the event that any of the regulators makes such a determination, Defendants shall immediately notify Plaintiffs and provide an opportunity for Plaintiffs and Defendants to meet to discuss these issues further.

12. This Joint Stipulation and order settles all claims and requests for injunctive relief that have been raised in Plaintiffs' September 22, 1997 Rule 60 (b) motion. With respect to claims other than those that have been raised in Plaintiffs' Rule 60 (b) motion, Plaintiffs reserve all rights and claims, and Defendants reserve 
all rights and defenses, including jurisdictional defenses. In any judicial action to enforce this Joint stipulation and order, Defendants reserve all rights and defenses, including jurisdictional defenses.

Respectfully submitted this Z2nd day of October, 1997,

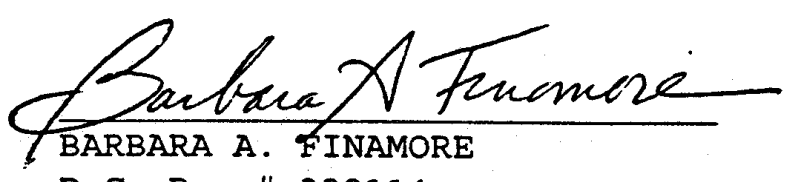

D.C. Bar \# 332114

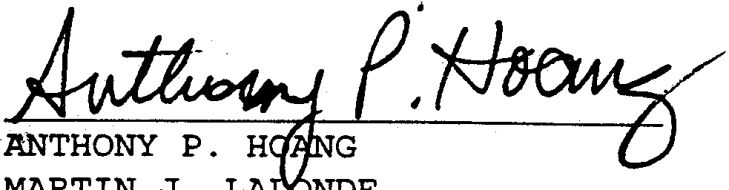
MARTIN J. LAIBNDE

Natural Resources Defense Council 1200 New York Avenue, N.W. Suite 400

Washington D.C. 20005

(202) $289-6868$

U.S. Department of Justice Environment and Natural Resources Division General Litigation Section P.O. Box 663 Washington, D.C. 20044-0663 (202) 305-0241 (202) 305-0247

Attorney for Plaintiffs

Attorneys for Defendants

\section{ORDER}

The foregoing Joint Stipulation is APPROVED and ENTERED as an order of this court on this 27 day of $C ; c .7997$.

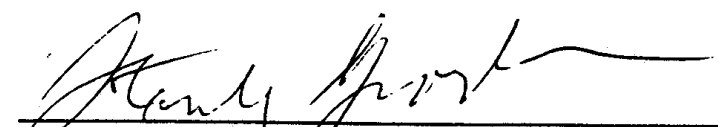

GONORABLE STANLEY SPORKIN United Statefo District Judge 

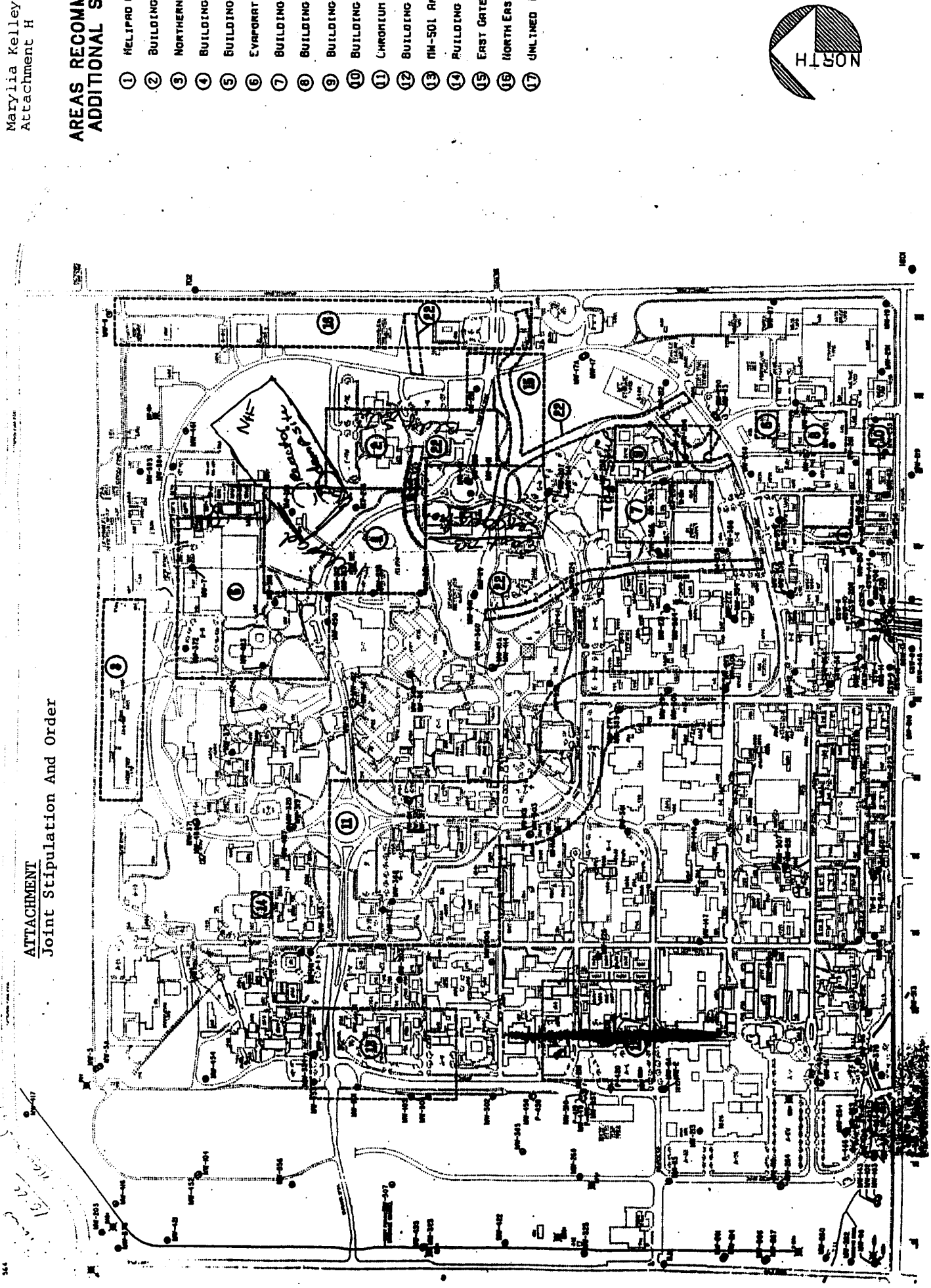
At2-1

ATTACHMENT 2:

NOTICE OF INTENT 
At2-2

[This page intentionally left blank.] 
[Federal Register: September 25, 1998 (Volume 63, Number 186)]

[Notices]

[Page 51341]

From the Federal Register Online via GPO Access [wais.access.gpo.gov]

[DOCID:fr25se98-47]

\section{DEPARTMENT OF ENERGY}

Supplemental Environmental Impact Statement for the Programmatic

Environmental Impact Statement for Stockpile Stewardship and Management

AGENCY: Department of Energy (DOE).

ACTION: Notice of intent.

SUMMARY: The Department of Energy announces its intent to prepare and issue a Supplemental Environmental Impact Statement (SEIS) for the National Ignition Facility (NIF) portion (Volume III, Appendix I) of the Programmatic Environmental Impact Statement for Stockpile Stewardship and Management (DOE/EIS-0236; September, 1997). The SEIS is being prepared pursuant to a Joint Stipulation and Order approved and entered as an order of the Court on October 27, 1997, in partial settlement of the lawsuit NRDC v. Pena, Civ. No. 97-936 (SS) (D.D.C.). The scope of the SEIS was established by the Joint Stipulation and Order and will cover, "the reasonably foreseeable significant adverse environmental impacts of continuing to construct and of operating NIF at LLNL with respect to any potential or confirmed contamination in the area by hazardous, toxic, and/or radioactive materials."

FOR FURTHER INFORMATION CONTACT: For further information about this SEIS or to be placed on the document distribution list, please call, toll-free, (877) 388-4930 or call or write Charles A. Taylor as indicated below: Charles A. Taylor, Document Manager, U.S. Department of Energy, L-293, 7000 East Avenue, P.O. Box 808, Livermore, CA 94550, Phone (925) 4233022, Facsimile (925) 424-3755.

For information about the DOE National Environmental Policy Act (NEPA) process, please contact: Carol Borgstrom, Director, Office of NEPA Policy and Assistance (EH-42), U.S. Department of Energy, 1000 Independence Ave, SW, Washington, DC 20585-0119, Phone: (202) 586-4600, Messages: (800) 472-2756, Facsimile: (202) 586-7031. 


\section{SUPPLEMENTARY INFORMATION:}

\section{Background}

The Lawrence Livermore National Laboratory (LLNL) was established in 1952 as a multi-disciplinary research and development center, operated by the University of California for the Department of Energy. LLNL is located in Livermore, California, about 40 miles southeast of San Francisco, California. LLNL consists of two portions, the main site in Livermore and the 300 Area near Tracy, California. The NIF is being constructed at the LLNL main site.

The National Ignition Facility is a part of the DOE's development of science-based, rather than underground nuclear test-based, stewardship of the nuclear weapons stockpile. In NIF, nuclear fusion of very small amounts of hydrogen isotopes is expected to be achieved using the energy inherent in laser light. The environmental consequences of construction and operation of NIF were addressed in detail in Appendix I of the Stockpile Stewardship and Management Programmatic EIS (SSM PEIS). The SSM PEIS addressed alternative plans for DOE's defense program activities related to nuclear weapons stockpile issues at several DOE laboratories, including LLNL. The Record of Decision (ROD) for the SSM PEIS was published in the Federal Register on December 26, 1996 (61 FR 68014). In the ROD, DOE announced a decision to proceed with construction and operation of NIF at LLNL. Ground-breaking for NIF occurred on May 29, 1997. Construction of the NIF is on-going and is expected to be completed by October 2003.

During site excavation for NIF in September 1997, buried electrical capacitors containing polychlorinated biphenyls and other items (buried drums that on analysis contained no hazardous, toxic and/or radioactive material) were discovered at the site. Several of the capacitors had leaked, contaminating surrounding soil. The capacitors and surrounding soil were cleaned up in accordance with State and Federal regulations. The possibility of such an event was unforeseen and therefore not addressed in the SSM PEIS. On September 22, 1997, the plaintiffs in NRDC v. Pena filed a motion under Rule 60(b) of the Federal Rules of Civil Procedure, in which they alleged that DOE knew but did not adequately analyze and disclose the risk of building NIF in an area that may contain buried hazardous, toxic, and/or radioactive waste. DOE denied the allegations in the plaintiffs' motion. In the Joint Stipulation and Order, which settled all claims in the plaintiffs' Rule 60(b) motion, DOE agreed to conduct a full evaluation of any potential risks to the human environment resulting from continuing to construct and operating the NIF at LLNL. Subsequent characterization activities that DOE conducted pursuant to the Joint Stipulation and Order, in order to determine if hazardous, toxic, and/or radioactive materials were buried in the northeast corner of LLNL, are complete. The results of these activities will be analyzed in the SEIS. Progress of the characterization activities was documented to the Court in the form of Quarterly Reports. These Quarterly Reports, along with a copy of the Joint Stipulation and Order is available at the LLNL Public Reading Room, East Gate Visitors Center, Greenville Road, Livermore, CA, or by calling Charles Taylor at the phone number provided at the beginning of this notice.

\section{SEIS Schedule}

In light of the Court's direction for the scope of this Supplemental EIS, no scoping meeting will be held. However, comments are welcome; please send comments to Charles 
Taylor at the address above. DOE expects to publish a Notice of Availability for the Draft SEIS in the Federal Register in December 1998. Public comments on the Draft SEIS will be received during a comment period of at least 45 days following publication of the Notice of Availability. The Notice of Availability will provide dates for public meetings that will be held in Livermore, California and Washington, DC approximately 30 days after the Notice of Availability is published. The draft and final SEIS will not contain any classified data.

Issued in Washington, DC on September 21, 1998.

Peter N. Brush,

Acting Assistant Secretary, Environment, Safety and Health.

[FR Doc. 98-25718 Filed 9-24-98; 8:45 am]

BILLING CODE 6450-01-U 
[This page intentionally left blank.] 
At3-1

ATTACHMENT 3:

AMENDED NOTICE OF INTENT 
At3-2

[This page intentionally left blank.] 
[Federal Register: August 5, 1999 (Volume 64, Number 150)]

[Notices]

[Page 42681]

From the Federal Register Online via GPO Access [wais.access.gpo.gov]

[DOCID:fr05au99-74]

\section{DEPARTMENT OF ENERGY}

Supplemental Environmental Impact Statement for the Programmatic

Environmental Impact Statement for Stockpile Stewardship and Management

AGENCY: Department of Energy.

ACTION: Amended notice of intent.

SUMMARY: The Department of Energy (DOE) is announcing a revised schedule for its preparation of a Draft Supplemental Environmental Impact Statement (SEIS) for the National Ignition Facility portion (Volume III, Appendix I) of the Programmatic Environmental Impact Statement for Stockpile Stewardship and Management (DOE/EIS-0236; September, 1997). This Draft SEIS is being prepared pursuant to a Joint Stipulation and Order approved and entered as an order of the court on October 27, 1997, in partial settlement of the lawsuit NRDC v. Richardson, Civ. No. 97-936 (SS) (D.D.C.).

FOR FURTHER INFORMATION CONTACT: For further information about this SEIS or to be placed on the document distribution list, please call, toll-free, (877) 388-4930, or call or write to Richard A. Scott, Document Manager, U.S. Department of Energy, L-293, P.O. Box 808, Livermore, CA 94550, Phone (925) 423-3022, Facsimile (925) 424-3755. For information about the DOE National Environmental Policy Act (NEPA) process, please contact: Carol Borgstrom, Director, Office of NEPA Policy and Assistance (EH-42), U.S. Department of Energy, 1000 Independence Ave, SW, Washington, DC 20585-0119, Phone: (202) 586-4600, Messages: (800) 472-2756, Facsimile: (202) 586-7031.

SUPPLEMENTARY INFORMATION: In a September 25, 1998, Federal Register notice (63 FR 51341), DOE announced that it expected to publish a Notice of Availability for the Draft SEIS in the Federal Register in December 1998. DOE now intends to publish the Notice of Availability no later than November 30, 1999. DOE has delayed the issuance of the Draft SEIS pending completion of a new investigation that was initiated in December 1998, in response to the discovery of contamination by polychlorinated biphenyls (PCBs) in soil that had been excavated from the Lawrence Livermore National Laboratory's East Traffic Circle, which is one of the areas covered by the Joint Stipulation and Order. After the discovery of the contaminated soil, 
DOE on December 23, 1998, notified the court and the plaintiffs in NRDC v. Richardson of the discovery; stated that the contaminated soil was being removed in accordance with applicable laws and regulations; and explained that a new investigation would be conducted into the extent of the contamination, and that DOE would delay issuance of the Draft SEIS pending the results of the new investigation.

Since then, DOE has filed two Quarterly Reports with the court, on March 24 and June 22, 1999, describing the progress that it has made in conducting the investigation and in analyzing its results for incorporation into the environmental impact analyses that will be included in the Draft SEIS. Copies of those Quarterly Reports, and of DOE's December 23, 1998 notice mentioned above, are available at the DOE Oakland Operations Office Public Reading Room on the first floor of the Federal Building, 1301 Clay Street, Oakland, CA; at the Lawrence Livermore National Laboratory Environmental Repository Public Reading Room, East Gate Visitors Center, Greenville Road, Livermore, CA; at the DOE Freedom of Information Act Public Reading Room, 1000 Independence Ave, SW, Washington, DC; or by calling Richard A. Scott at the telephone number provided above.

Issued in Washington, DC on July 30, 1999.

Jonathan S. Ventura, Acting Executive Assistant, Office of Defense Programs.

[FR Doc. 99-20143 Filed 8-4-99; 8:45 am]

BILLING CODE 6450-01-P 